\title{
1791 metų Verkių dvaro inventorius
}

\section{Rūta Janonienè}

Vilniaus dailès akademijos Dailètyros institutas

Dominikonų g. 15, LT-01131 Vilnius

ruta.janoniene@gmail.com

— Iki šiol nebuvo pakankamai rašytinių duomenų Verkių ansamblio raidos vyskupo Ignoto Juozapo Masalskio (1726-1794) valdymo laikotarpiu tyrimams. Šią spragą iš dalies užpildo $1791 \mathrm{~m}$. Verkių dvaro inventorius, kurio vertimas ị lietuvių kalbą čia publikuojamas. Inventorius, pasirašytas vyskupo valdų administratoriaus Kazimiero Hornovskio (1756-1818), surašytas tvarkingai, ịištas kaip atskira knyga. Nors jame neaprašyta centrinė, rezidencinè, pilimi vadinta dvaro dalis, kurią sudarè mūrinių pastatų kompleksas (senieji rūmai, naujieji centriniai rūmai ir dvi šoninès oficinos), jo medžiaga gali būti įdomi ir reikšminga ịvairių sričiu istorijos tyrimams - dokumentas leidžia naujai pažvelgti ne tik ị Verkiu architektūrinio ansamblio raidą, bet suteikia žinių ir apie dvarui priklausiusių kaimų ir gyvenviečių, t. y. apie šiaurinių Vilniaus apylinkių, istoriją. Gucevičius, Kazimieras Hornovskis. 
$1791 \mathrm{~m}$. Verkiu dvaro inventorių kartu su kitais šio dvaro archyvo likučiais Vokietijos nacionaliniame archyve Koblence surado Myro pilies (Baltarusija) direktorè dr. Olga Popko. 2016 m. kai kurių Verkių dokumentų skaitmeninès kopijos buvo perduotos Lietuvos valstybès istorijos archyvui, jais ir naudotasi rengiant šią publikaciją. $1791 \mathrm{~m}$. inventoriaus medžiaga iš dalies jau buvo panaudota rengiant publikaciją apie Verkių sodus². Vis dèlto jame esanti informacija gali būti įdomi ir reikšminga įvairių sričių istorijos tyrimams, todèl viso dokumento paskelbimas yra prasmingas. Dokumentas leidžia naujai pažvelgti ne tik ị Verkių architektūrinio ansamblio raidą, bet suteikia žinių ir apie dvarui priklausiusių kaimų ir gyvenviečių, t. y. apie šiaurinių Vilniaus apylinkių, istoriją.

Ignotas Juozapas Masalskis (1726-1794) Vilniaus vyskupu nominuotas $1762 \mathrm{~m}$., taigi tais metais jis perėmè ir vyskupų vasaros rezidenciją Verkius. Vargu ar iš karto jis ėmėsi didesnių šio dvaro pertvarkų. $1766 \mathrm{~m}$. inventorius, žinomas iš $1806 \mathrm{~m}$. nuorašo ${ }^{3}$, iš esmès rodo dar nedaug pakitusi ansambli, paliktą Masalskio pirmtakų. $1776 \mathrm{~m}$. Verkiu palivarko inventoriuje $^{4}$ atsispindi ūkinėje dvaro dalyje jau ịvykę pokyčiai. Pagal $1780 \mathrm{~m}$. Masalskio sutarti su Vilniaus kapitula Verkiai tapo jo paveldima nuosavybe. 1789 m. pabaigoje Masalskis išvyko į užsienį ir ị Lietuvą sugrį̌žo tik $1792 \mathrm{~m}$. pradžioje, taigi inventorius sudarytas jam nesant. Dokumentą pasirašė vyskupo patikètinis, Lomazų seniūnas, tuometinis Vilniaus vaivadijos karinis ir civilinis komisaras Kazimieras Hornovskis (Hornowski, 1756-1818), nuo jaunystės artimai bendravęs su architektu Laurynu Gucevičiumi ${ }^{5}$. 1779 m. vasario 1 d. L. Gucevičius oficialiai tapo vyskupo I. J. Masalskio architektu ${ }^{6}$,

1 Verkių dvaro inventorius, 1791, in: Lietuvos valstybės istorijos archyvas (toliau - LVIA), f. 1999, ap. 9, b. 3 (Bundesarchiv Koblenz, Nachlass Radziwill, No. 1039).

2 Rūta Janonienė, „Verkių sodai vyskupo Ignoto Jokūbo Masalskio laikais“, in: Acta Academiae Artium Vilnensis, Vilnius, 2018, t. 88-89: Sodai: tradicijos, ivaizdžiai, simboliai Lietuvos kultūroje, sud. Rūta Janonienè, p. 89-104.

3 Verkių dvaro inventorius, sudarytas 1766 m., aktikuotas 1806 m., in: LVIA, f. 1999, ap. 9, b. 7 (Bundesarchiv Koblenz, Nachlass Radziwill, No. 1043).

41776 m. Verkių palivarko inventorius, in: LVIA, f. 1999, ap. 9, b. 2 (Bundesarchiv Koblenz, Nachlass Radziwill, No. 1038).

5 Plačiau apie L. Gucevičiaus ryšius su K. Hornovskiu žr.: Rūta Janonienė, „Lauryno Gucevičiaus šeimos likimai“, in: Kupiškis. Kultūra ir istorija, 2017, Nr. 15, p. 12-21; Eadem, „Kostrovickiai iš Arnionių - šeima, padejjusi išsaugoti Lauryno Gucevičiaus atminimą“, in: Acta Academiae Artium Vilnensis, Vilnius, 2017, t. 86-87: (Iš)koduota istorija architektūroje, sud. Rasa Butvilaitè, Edita Povilauskaitè-Leliugienè, p. 219-233.

6 Vyskupo J. I. Masalskio kreditorių ir kitų asmenų byla su Potockiais, XIX a. pr., in: LVIA, f. 344 , ap. 1, b. $16,1.474$. 


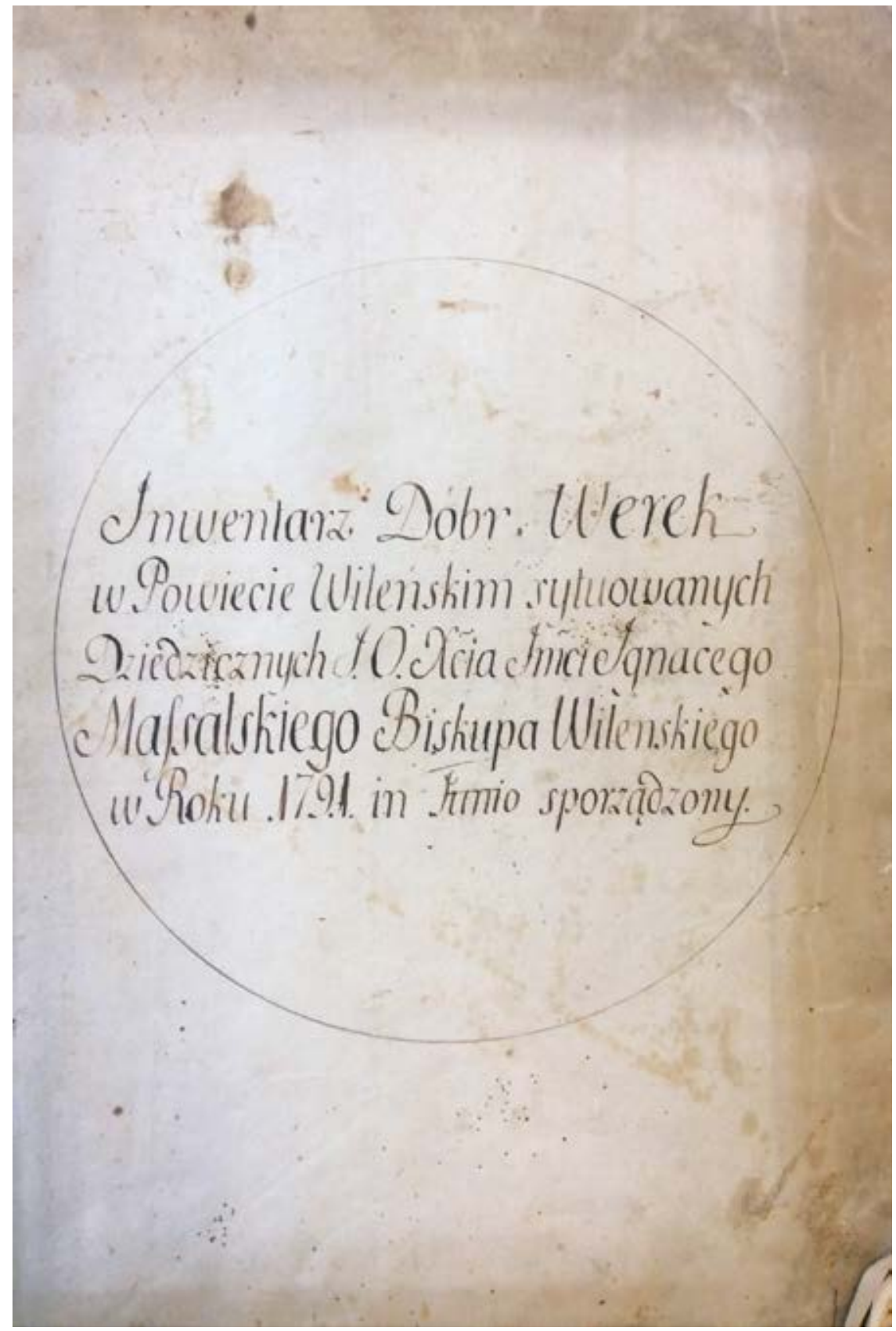

1. 
o $1780 \mathrm{~m}$. K. Hornovskis - vyskupo valdų administratoriumi Inventorius surašytas labai tvarkingai, ịrištas kaip atskira knyga, turinti viršeli su užrašu „Nr. 32.1791 metų Jo Šviesybės kunigaikščio Masalskio, Vilniaus vyskupo, paveldimų Verkių valdų inventorius, sudarytas Jo Malonybės Pono Kazimiero Hornovskio“8 ir titulini puslapi su užrašu „Jo Šviesybės kunigaikščio Ignaco Masalskio paveldimų Verkių valdų, esančių Vilniaus paviete, inventorius, sudarytas $1791 \mathrm{~m}$. birželį “9. Pirmoje rankraščio dalyje numeruoti lapai, o nuo poskyrio „Verkiu dvaro valstiečių, t. y. gyvenviečių, žmonių, kinkomų gyvulių, žemės ir miškų bei mokesčių ir prievolių aprašymas" (1. 33) pereinama prie puslapių numeracijos, tas pats principas išlaikytas ir vertime.

Reikia atkreipti dėmesĭ, kad šiame inventoriuje, deja, neaprašyta centrinè, rezidencinè, pilimi vadinta dvaro dalis, kurią sudarė mūriniu pastatų kompleksas: senieji rūmai, naujieji centriniai rūmai ir dvi šoninès oficinos ${ }^{10}$. Matyt, šiai ansamblio daliai buvo sudarytas atskiras inventorius, kuris iki šiol nerastas. Kitoje dvaro teritorijoje (neskaitant jam priklausančių kaimų) buvo per 50 pastatų (dauguma - mediniai, ant mūrinių pamatų), dvaro žemėse stovėjo keli malūnai, smuklès. Mūrinių pastatų priskaičiuojama daugiau kaip dešimt, daugelis jų, nors ir daugiau ar mažiau perstatyti, išliko iki mūsų dienų. Ypač svarbios informacijos pateikta apie dviejų aukštų gyvenamaji namą virš ledainès, dažnai dabar vadinamą paviljonu. Iš inventoriaus sužinome tikslų jo autentišką suplanavimą ir funkciją, taip pat atskiru patalpu puošybą. Prieangyje buvo suklotos juodų perdegtų plytų grindys, kambariai buvo dažyti skirtingomis spalvomis (pvz., pilka, žalia, rausva, balta), kai kuriuose kambariuose buvo puošnūs tapyti karnizai su frizais, kai kur lubos dažytos mėlynai. Vieno antro aukšto kabineto sienos buvo dažytos tamsiai, palubėje puoštos tapytu karnizu, lubos dažytos rausvai, o ant vienos sienos skoningai nutapytas peizažas, vaizduojantis jūros uostą. Pateikti vertingi duomenys apie medinius klasicistinius namus, neabejotinai, taip pat projektuotus L. Gucevičiaus. Visi mediniai Gucevičiaus

7 Vyskupo J. I. Masalskio instrukcija K. Hornovskiui, 1780, in: LVIA, f. 1135, ap. 20, b. 60, $17800517,1.1$.

8 Orig.: Nr. 32 / Roku 1791 / Inwentarz Dóbr Werek / Dziedzicznych J. O. Xiążęcia Massalskiego Biskupa Wilenskie[go] / przez WJ Pana Kazim. Hornowskiego / sporządzony.

9 Orig.: Inwentarz Dóbr Werek/ w Powiecie Wileńskim sytuowanych / Dziedzicznych J. O. Xcia Jmci Ignacego / Massalskiego Biskupa Wilenskiego / w Roku 1791 in Junio sporządzony.

10 Ankstyviausias šiuo metu žinomas šių keturių mūrinių pastatų aprašymas: $1803 \mathrm{~m}$. Verkių inventorius, in: LVIA, f. 1. 258-258v. 
statyti namai buvo paprasto, simetriško plano, dažyti pelenų spalva, jų stogai (kaip ir mūrinių pastatų) dažyti raudonai, visų namų fasaduose buvo didesni ar mažesni kolonų portikai arba igilintos lodžijos su kolonomis. İspūdinga buvo prie Neries stovèjusi lentpjūvè - ją aplink supo 42 medinių kolonų galerija. Būdingas Gucevičiaus statinių bruožas - dažnai pagalbinèse patalpose ar prieangiuose klotos juodų perdegtu plytų grindys, neretai lubos formuotos iš kalkių ir gipso, taip pat plačiai naudotos ir lentinès lubos bei grindys. Labai daug dèmesio naujai statytuose Verkių namuose buvo skirta apšildymui - statytos modernios krosnys (dažnai rudų, kavos spalvos koklių), kuriose buvo įtaisytos grotelès pelenams nubyrèti ir įrengti dūmų skląsčiai. Visi krosnių dūmtraukiai suvesti ị vieną kaminą stogo centre, ilgesnių rūmų atveju - i du kaminus.

Rengiant inventoriaus vertimą ị lietuvių kalbą skyrybos ženklai vartoti remiantis dabartiniais reikalavimais. Antroje inventoriaus dalyje, kur surašyta dvaro pastatuose buvęs kilnojamasis turtas ir dvarui priklausiusių gyvenviečių bei kaimų gyventojai, atsisakyta originale esančių lentelių.

\section{Vertimas}

(1. 1) Verkių dvaro pastatų ant kalno aprašymas

1-as pastatas, kuriame [gyvena] stalius Reimeris (Reymer), senas, pastatytas iš tašytų rąstų ant plytinių pamatų, stogas dengtas gontais ${ }^{11}$, nuo kiemelio pusès pastato centre iškištas prieangis, ̨̣einant i priemenę vienvèrès lentelemis apkaltos ${ }^{12}$ durys ant vyrių, kablių, su mediniu skląsčiu, priemenėje vienoje pusėje virtuvè, skirta valgiui gaminti, kitoje pusėje - plytinè duonkepè krosnis, iš jos kaminas išvestas virš stogo; iš tos virtuvès einant toliau vienvėrès durys ant vyrių ir kablių ten, kur priemenėje iškastas rūselis su gulinčiomis dvivèrèmis durimis ant bėgūnų ${ }^{13}$, ten pat sienoje mažas langelis su stiklu. Iš priemenès einant ị kairę pusę i gyvenamajji kambarị staliaus darbo vienvèrès durys ant vyrių, kablių, su geležine nulenkiama rankena, su skląsčiu ir geležiniais kabliukais. Kambaryje keturi langai

11 Gontas - tradicinė stogų dengimo medžiaga, trikampio pjūvio lentelè, turinti griovelị platesniame šone, ị kurị ịsistato plonasis gretimo gonto šonas. Lentelès gaminamos iš spygliuočių (eglès, pušies) arba drebulès, alksnio medienos, ịprastai yra nuo 7 iki $14 \mathrm{~cm}$ pločio ir apie 60-70 cm ilgio, paviršius šiek tiek lenktas.

12 Orig.: futrowane.

13 Bègūnas - medinis durų vyris. 
mediniuose rèmuose. Krosnis sena, žalių ir baltų koklių, o prie jos - iš plytų sumūrytas židinys. İ kamarą durys taip pat vienvèrès, ant vyrių ir kablių, su geležiniu skląsčiu ir kilpomis, kitos mažos durelès ị rūseli apkaltos lentelèmis, ant prancūzišku vyrių, su medine rankena. Vienas langas įtvirtintas glaistu. Trečios durys ị sandèliuką ant vyrių ir kablių, sandèliuke langas mediniuose rëmuose. Grindys priemenėje iš plytų, kambaryje ir kamaroje bei sandèliuke grindys ir lubos iš lentų $u^{14}$. Penkios langinès ant bėgūnų. Iš priemenès ị dešinę vienos durys ị dirbtuvę, vienvèrès, ant vyrių ir kablių, apkaltos lentelèmis, su geležine apvalia rankena, kitos durys ị prieangì, dvivèrès, taip pat apkaltos lentelėmis, ant vyrių ir kablių; langų mediniuose rèmuose dešimt. Dvi pilkų koklių balintos krosnys, prie vienos iš jų iš virtuvės pusės - židinys, iš kitos kaminas išvestas virš stogo. Išorẻje ir viduje yra penkios poros statramsčiu sienoms sutvirtinti, prie jų - aštuoni geležiniai varžtai su pleištais. Grindys iš plytų, lubos sudètos iš lentų.

Nedidelè arklidė dviems arkliams sena, pastatyta iš sijų, dengta gontais, joje du langeliai su sklendèmis, èdžios, grindys ir lubos iš lentų. Šalia pašiūrè ant stulpų medžiagoms džiovinti, viršuje uždengta pusapvalèmis lentomis ${ }^{15}$, o priekyje trys eilès apirusių gontų. Antra pašiūrè taip pat ant stulpų, maža, sena, dengta lentomis, prie jos mažas darželis aptvertas statinių tvora. Kitas daržas didesnis už pastato, aptvertas iš dalies statinių, iš dalies pinučiu tvoromis. Dabar tuščias.

2-as pastatas tuščias, labai senas, iš tokios pat medienos, ant mūriniu pamatų, stogas dengtas gontais, senas, skylètas. (l. 1v) Nuo gatvès pusės virš sienos sienelè prūsišku mūru iki stogo pastatyta, skylèta. İeinant i priemenę durys iš lentų, senos, dvivèrès ant vyrių ir kablių; priemenèje laiptai ị rūsị ir medinès durys ant vyrių ir kablių su geležiniu skląsčiu ir kilpomis. Tas rūselis iš kiemo pusès uždengtas lentomis, senas, iš dalies apgriuvęs. İ kambarị durys vienvėrès ant vyrių, kablių, su nulenkiama rankena, su geležiniais kabliukais ir kilpelėmis užsidaryti iš vidaus. Langai mediniuose rẻmuose keturi, juose vienas stiklas sudaužytas, prie trijų daliu vyriukai. Langinè viena ant vyrių, su kabliais. Krosnis pilkų koklių, sena, apšildanti kambarị ir kamarą, prie jos kryžminè duonkepė krosnis iš plytų, su kaminu, išvestu virš stogo. I kamarą durys iš lentų, senos, dvivèrès, ant

14 Orig: tarcica - lenta, išpjauta lentpjūvèje (ne rankiniu būdu).

15 Orig.: opolkami; opolka, opótka - lenta, gauta nupjovus rąsto kraštą, todèl viena jos pusè pusapvalè. 
vyrių, kablių, su skląsčiu ir kabliuku bei kilpelėmis uždarymui. Vienas langas mediniuose rèmuose, jame du stiklai išdaužti. Iš kiemo pusės langinė ant vyrių, kablių, su kabliuku ir kilpelėmis. I sandèliuką durys vienvèrès ant vyrių ir kablių, langas tik vienos dalies, mediniuose rèmuose, jame vienas stiklas išdaužtas, kita dalis be stiklo, lenta užkalta. Kambaryje, kamaroje ir sandėliuke grindys iš plytų, lubos iš lentų. Nedidelẻ kalvẻ sena, tuščia, sienos apgriuvusios, be durų, stogas, gontais dengtas, senas; viduje iš plytų mūrytas žaizdras ${ }^{16}$ su virš stogo išvestu kaminu. Daržas tuščias, nedirbamas, be aptvaro. Dabar tuščias.

3-ias pastatas, kuriame [gyvena] šaltkalvis Vincentas Stankevičius (Stankiewicz), senas, papuvęs, tokios pat medienos, jo stogas gontinis, senas, galuose frontonai prūsišku mūru pastatyti, skylèti, sienos ant mūrinių pamatų. I priemenę durys dvivèrès, senos, ant vyrių, kablių, su antaba ${ }^{17}$ ir geležine nulenkiama rankena ir su skląsčiu bei kilpomis. Iš priemenès i kambarị pusè durų aklinai užkalta, kita pusè ant vyrių, kablių, su antaba ir geležine nulenkiama rankena bei kabliuku su kilpelèmis. Trys langai mediniuose rėmuose, stiklo gabaliukai iš dalies sudužę. Gale pertvara iš lentu su vienvėrèmis durimis ant vyrių ir kablių, su skląsčiu ir kilpelèmis. Krosnis plytinè, sena, apšildanti kambarị ir kamarą, prie jos kryžminė duonkepẻ krosnis taip pat iš plytų, su kaminu, išvestu virš stogo. I kamarą durys vienvèrès ant vyrių, kablių, su skląsčiu kitoje pusejje ir kilpelèmis. Langas vienas, tokio pat stiklo (l. 2), dvivèris, prie vienos jo dalies vyriukai ir kabliukai užkabinimui. Prie krosnies mažas židinėlis. I sandèliuką vienvėrès durys ant vyrių, kablių, su skląsčiu ir kilpomis, jame vienas sveikas langas su langine ant vyrių ir kablių, su kabliuku. Kalvè gera, pastatyta iš dvišonès medienos ${ }^{18}$, stogas dengtas čerpèmis, durys į ją vienvèrès, ant vyrių, kablių, su prancūziška spyna ir raktu, su skląsčiu viduje ir kilpomis. Langai du, išdaužyti, su dvejomis langinėmis ant vyrių ir geležiniais štiftais uždarymui. Daržas dirbamas, nedaug aptvertas. Dabar tuščias.

4-as pastatas tuščias, senas, iš tokios pačios medienos, ant mūrinių pamatų, neseniai gontais uždengtas. I priemenę durys senos, dvivèrès ant vyrių, kablių, su skląsčiu ir geležinėmis kilpomis bei nulenkiama rankena, ten pat kamarèlè, neseniai atitverta mūrtašiais, su durimis ant vyrių, kablių,

16 Orig.: horno.

17 Antaba - (vok. Handhabe - rankena) - dekoratyvi metalinè (kartais paauksuota, sidabrinė ar bronzinė) žiedo pavidalo durų, vartų ar baldų rankena.

18 Iš dviejų šonų aptašytų rąstų. 
su sena, taisytina įleidžiama spyna ir raktu; priemenejje vienas mažas stiklinis langelis, grindys iš lentų (be vienos lentos), lubos tokios pat. Iš priemenės laiptai ị viršų. I kambarị kairėje pusèje dvivèrès durys ant vyrių, kablių, su nulenkiama rankena ir geležine rankenèle, kita [durų] pusė su kabliuku apačioje užkabinimui. Kambaryje trys langai mediniuose rẻmuose, iš jų vienas dvivèris, ant vyrių su dviem skląsčiais viduje. Krosnis, apšildanti kambarị ir kamarą, iš vienos pusès baltų naujų koklių, iš kamaros pusės iš senų koklių, prie jos kryžminė duonkepė krosnis iš plytų su kaminu, išvestu virš stogo. I kamarą durys dvivèrès, dažytos, ant vyrių, kablių, su nulenkiama rankena ir skląsčiu su geležinėmis kilpomis. Langai iš dalies išdaužyti, vienas dvivėris ant vyrių, kablių, su skląsčiu ir kilpelèmis. I sandèliuką durys vienvėrès ant vyrių, kablių, su skląsčiu ir geležinėmis kilpomis. Vienas langas mediniuose rėmuose. Kambaryje, kamaroje ir sandèliuke grindys iš plytų, lubos iš lentų. Nuo daržo pusès to pastato gale pristatyta arklidè su medinėmis ėdžiomis, kopėčiomis ir grindimis, su langeliu mëšlui išmesti; i arklidę durys didelès vienvèrès ant vyrių, kablių, su sugedusia ịleidžiama spyna, su skląsčiu ir kilpomis, stogas šiaudais dengtas. Prie šio gyvenamojo namo yra keturios langinės ant vyrių, geležinių kablių, su kabliuku ir kilpomis užkabinimui. Kita arklidè penkto pastato gale, tokio pat dydžio, su èdžiomis, kopéčiomis, grindys iš lentų, ị ją durys didelès vienvèrès ant vyrių, kablių, su įleidžiama spyna ir raktu, su (l. 2v) geležiniu kabliuku ir kilpomis. Trečia maža arklidè kieme iš lentų pastatyta, lentomis dengta ir išklota, sena, su dvivėrèmis durimis ant bėgūnų, su geležinėmis antabomis, vienos jų pusès nėra. Nuo gatvès tvora su dvivėriais sugadintais vartais, tarp didžiụjų arklidžių nuo daržo pusès taip pat tvora su mažomis durelėmis ant vyrių, su kabliuku ir geležinėmis kilpomis. Daržas dirbamas, aptvertas pinučių tvora.

5-as pastatas, kur [gyvena] sodininkas Severinas, iš tokios pat medienos, labai senas, ant mūrinių pamatų, stogas senas, dengtas gontais, ì priemenę durys dvivèrès, pusė jų aklinai užkalta, kita pusė ant vyrių, kablių, su geležine nulenkiama rankena, su skląsčiu ir kilpomis. Iš priemenès ị kairę pusę ì kambarị senos dvivèrès durys, apkaltos lentelèmis, ant vyrių, kablių, su geležine nulenkiama rankena ir geležiniais kabliukais užkabinimui 
ir su kilpelėmis; trys langai mediniuose rėmuose, juose viena dalis atsidaranti, ant vyrių, su kabliuku užkabinimui. Krosnis gerų žalių koklių, apšildanti kambarị ir kamarą, prie jos sena duonkepè krosnis su kaminu, išvestu virš stogo. I kamarą vienvèrès durys ant vyrių su skląsčiu ir geležinėmis kilpomis, joje vienas langas mediniuose rėmuose, su viena atsidarančia dalimi ant vyrių, kabliukų ir su kabliuku užkabinimui. Iš kamaros ị sandėliuką vienvėrès durys ant vyrių, kablių, su skląsčiu ir kilpomis, užrakinti kabančia spyna. Langas vienas, tokio pat stiklo, mediniuose rèmuose. Kambaryje grindys iš dalies iš plytų, iš dalies iš lentų, kamaroje iš lentų, o sandèliuke iš plytų, lubos visur iš lentų. Langinės trys ant bėgūnų. Nuo gatvės statinių tvora su paprastais vartais. Daržas dirbamas, aptvertas pynučių tvora.

6-as pastatas tuščias, tokios pat medienos, senas, ant mūrinių pamatu, stogas gontais dengtas, neseniai naujai pataisytas. I priemenę durys dvivèrès, senos, ant vyrių, kablių, su nulenkiama geležine rankena ir su skląsčiu bei geležinėmis kilpomis. Priemenėje mūrinis rūsys be durų, uždengtas per pusę perpjautais rąstais, virš jo laiptai ị viršų. I kambarị durys senos, dvivèrès ant vyrių, kablių, su geležine nulenkiama rankena. Langai trys geri, mediniuose rèmuose. Krosnis pilkų koklių, apšildanti kambarį ir kamarą, prie jos sena plytinė duonkepė krosnis su kaminu, išvestu virš stogo. İ kamarą durys vienvèrès ant vyrių, kablių, su skląsčiu ir kilpomis, langas taip pat geras. I sandèliuką durys vienvèrès, senos, ant vyrių, kablių, su skląčiu ir kilpomis, langas taip pat sveikas. Kambaryje, kamaroje ir sandèliuke grindys iš plytų, lubos iš lentų. Tame name yra trys pusantro colio ${ }^{19}$ lentos. Darže pastatyta vidutinio dydžio stoginè iš dvišonès medienos, i ją vienvèrès durys ant vyrių, kablių, (1. 3) su skląsčiu ir kilpomis užrakinti kabančia spyna, viduje apskrita krosnis iš plytų su dviem ertmėmis kokliams degti, su kaminu, išvestu virš stogo. Daržas dirbamas, aptvertas pynučių tvora.

7-as pastatas, kur [gyvena] stalius Hanuveris (Hanówer), iš tokios pat medienos ant mūrinių pamatų, senas stogas geras, dengtas gontais. I priemenę durys vienvèrès, apkaltos lentelèmis, ant vyrių, kablių, su geležine nulenkiama rankena ir skląsčiu bei viena kilpa. Priemenėje mūrinė virtuvèlè su kaminu, išvestu virš stogo. I kambarị durys taip pat vienvèrès, apkaltos lentelèmis, ant vyrių, kablių, su nulenkiama geležine rankena. Keturi 
geri langai mediniuose rẻmuose, tik vienas stiklas išmuštas. Krosnis baltų koklių, apšildanti kambarị ir kamarą, prie jos kryžminė duonkepė krosnis. I kamarą durys vienvėrès, apkaltos lentelèmis, su langeliu, ant vyrių ir kablių, su prancūziška spyna su raktu ir rankena. Langas sveikas, ịtvirtintas glaistu. Židinys prie krosnies iš plytų. I dešinę pusę iš kamaros naujos durys ị kitą kamarèlę, skirtą podèliui, vienvèrès, apkaltos lentelèmis, ant vyrių ir kablių, su nulenkiama geležine rankena. Vienas langas sveikas, ittvirtintas glaistu. Iš kamarèlès i stoginę tik vieta durims, laikinai uždengiama lenta. Kairèje pusėje ị sandèliuką durys vienvèrès, apkaltos lentelèmis, ant geležinių vyrių ir kablių. Langas jame vienas, ịtvirtintas glaistu, jo atsidaranti pusè ant vyrių, su kabliuku užkabinimui. Priemenėje, kambaryje, kamarèlèje, skirtoje podèliui, ir sandèliuke grindys iš plytų, vidurinėje kamaroje iš lentų, lubos visur taip pat iš lentų. Stoginès staliaus medžiagoms laikyti trys sienos pastatytos iš dvišonès medienos, o ketvirtu šonu ji glaudžiasi prie gyvenamojo namo galo, jos stogas iš dviejų pusių dengtas skiedromis, iš trečios - pusapvalèmis lentomis. Durys dvivèrès, pusės jų nėra, prie kitos pusès yra dvi poros vyrių su kabliais. Toje stoginėje medžiu sutvirtintas rūsys su mediniais laipteliais, be durų.

Daržas dirbamas, aptvertas pynučių tvora, tame darže nuo senos kalvès likęs mūrinis žaizdras su kaminu iš plytų. Šalia to daržo atskirai - arklidė šešiems arkliams, pastatyta iš dvišonès medienos šulų, stogas plokščias, dengtas pusapvalemis lentomis, durys dvivėrès, senos, ant vyrių ir kablių, su geležine velke, iš vidaus su skląsčiu ir kilpomis; viduje trumpos èdžios su kopėčiomis, grindys iš storų lentų, langelis su stiklu mažas, sveikas.

Ledainè iš dvišonès medienos pastatyta žemëje, stogas dengtas čerpėmis, perdengimas medinis, užpiltas smėliu, vienoje vietoje igriuvęs, tame perdengime padarytos dūmtakio formos durys, kairèje pusèje, kur yra užtvarai ledui sudėti, durys dvivèrès iš lentų, ant vyrių, (l. 3v) kablių, su prancūziška spyna ir raktu; šalia durys taip pat vienvèrès, ant vyrių ir kablių, su skląsčiu ir kilpomis užrakinti kabančia spyna, pro kurias iejejus mediniais laiptais [patenkama] i lentomis išgrịstą koridorių, kairèje jo pusèje ì rūsí, kuriame laikomi gèrimai, vienos dvivèrès durys ant vyrių ir kablių, su prancūziška spyna ir raktu, taip pat su skląsčiu ir dviem kilpomis bei su 
ratuku, šalia ị kitą, mažesnị, rūsị durys su tokiais pat apkaustais. Didesniame rūsyje vienas mažas langelis be stiklo su geležinėmis grotomis, aukščiau paminèto koridoriaus gale viršuje toks pats langelis su geležinėmis grotomis ir langinėle ant vyrių ir kablių. Visa ta slabada smarkiai apgriauta Rusijos kariuomenès.

Šalia tos ledainės tarp dviejų padarytų stulpų yra nedidelis varpelis statybose dirbantiems.

Dviaukštis namas $^{20}$ ant aukščiau aprašytos ledainès, mūrinis, turintis viršuje apvalų kupolą su stikliniu apvaliu langu, iš priekio fasadas su prieangiu, viduje papuoštu dviem kolonomis, išklotu juodomis molinėmis grindimis, dešinėje pirmo aukšto pusėje dvivèrès durys, dažytos pelenų spalva, su prancūziška spyna ir raktu bei su dviem apačioje ir viršuje sklendèmis, pro jas ịejus ị pirmą rausvai dažytą kambarị jame du dvivèriai langai, sutvirtinti glaistu, dažyti pelenų spalva, kiekviename ju yra aštuoni stiklo lakštai ant vyrių, turintys po dvi apačioje ir viršuje sklendes. Iš to kambario ị vidurinị, didesnị, žaliai dažytą su karnizu, durys apkaltos lentelèmis, dvivèrès, dažytos pelenų spalva, ant vyrių ir kablių, su prancūziška spyna ir rankena bei dviem sklendèmis, jame langu taip pat du, krosnis švediška koklinė, apšildanti du kambarius, kūrenama iš vidaus, su vienvėrèmis geležinėmis durelėmis, apačioje kanalas, ị kurị krenta pelenai, perdengtas aštuoniais geležiniais strypais, viduje tos krosnies geležinis krosniakaištis su strypu geležiniam dūmtraukiui uždaryti; šalia tos krosnies židinys su medine lenta, apačioje turintis geležinius strypus, per kuriuos nukrenta pelenai. Iš to kambario ì paskutinị, mažesnị, durys taip pat dvivèrès ant vyrių su prancūziška spyna ir rankena bei dviem sklendèmis. Langas jame taip pat vienas. Visuose trijuose kambariuose grindys sudètos iš lentų, lubos dažytos mėlyna spalva. Iš aukščiau paminèto prieangio ị salę vienos durys dvivèrès fasuotos $^{21}$ su prancūziška spyna, rankena, raktu ir dviem sklendėmis, joje maža virtuvėlè su geležinès skardos gobtuvu, grindys molinès, kvadratinès, juodos, viduryje apvalus langas su lenta, pro kuri meta ledą i ledainę. Kitos durys iki pusès stiklinès, ant vyrių ir kablių, be spynos, jose

$201802 \mathrm{~m}$. šį namą nuomojo revizorius Simonas Zublevičius (Zublewicz), sudaręs tų metų dvaro inventorių (1802-1806 m. Verkių dvaro inventorius, 1. 8). Dabar pastatas, vadinamas Verkiụ dvaro sodybos paviljonu, yra Žaliujų Ežerų g. 53 (Kultūros vertybių registro kodas 24995).

21 Orig. fasowane - durys iš dviejų sluoksnių medienos, tarp kurių buvo dedamas ịvairių izoliacinių (šildymo) medžiagų sluoksnis, arba tiesiog iš sukaltos iš pavienių lentelių, žr. Marian Janusz Kawałko, „Opis zamku krasnostawskiego (1765)“, in: Nestor, 2015, Nr. 4 (24), p. 26. Senosios lenku kalbos žodynuose terminas neapibrèžtas. 
du stiklai išdaužti, (1.4) pro jas įejus ị tarnų kambarị jame du dvivèriai langai kaip aukščiau, su vienu išmuštu stiklu. Švediška krosnis kavos spalvos koklių, apšildanti ir kitą kambarèli, su dvivèrėmis geležinėmis durelèmis, panaši i i pirmą; grindys iš lentų, lubos iš kalkių ir gipso, nedažytos. Toliau einant i sandèli durys taip pat dvivèrès, ant vyrių, kablių, su prancūziška spyna, rankena ir raktu bei dviem sklendèmis, dažytos pelenų spalva; sandèlyje toks pat vienas langas. Iš aukščiau minèto prieangio ị kairę dvivėrès pelenų spalvos durys ant vyrių, kablių, su prancūziška spyna, rankena bei raktu ir dviem sklendèmis ị priemenę, kurioje du dvivèriai langai, po dešine ị vieną kambarị apačioje pelenų spalvos durys su tokiais pat apkaustais ir spyna, kambaryje švediška kavos spalvos kokliụ krosnis su geležinėmis durelèmis, panaši i aukščiau aprašytas, taip pat du dvigubi langai, grindys iš lentų, lubos iš kalkių ir gipso. Iš priemenès einant suktais staliaus darbo laiptais su turéklais i antrą aukštą tokie pat du langai, iš ten ị dešinę durys, fasuotos vienvèrès ant vyrių, su prancūziška spyna ir rankena, pro jas ięjus i prieangị, pačiame fasade atitvertą tekintais pelenų spalva dažytais turèklais, grindys iš lentų, o virš ir po juo lubos. Einant tuo prieangiu tiesiai kitos durys ị mažą kambarèlį, dažytos pelenų spalva, ant vyrių ir kablių, su prancūziška spyna, raktu ir rankena su geležiniu rutuliu, jame toks pat langas vienas, sienos dažytos pelenų spalva, židinys - juodai. Iš to kambario ị vidurini didesnị kambarị dvivèrès fasuotos durys, dažytos baltai, ant vyrių, kablių, su prancūziška spyna ir rutuliu prie jos bei dviem sklendèmis viršuje ir apačioje, jame du tokie pat dvivèriai langai, sienos baltai dažytos su tapytu karnizu su dantukais, švediška krosnis baltų koklių, apšildanti du kambarius, su dvigubomis durimis ant vyriu, su rankenèle ir geležiniais strypais apačioje, su skardiniu krosniakaiščiu užkišti geležinės skardos vamzdi, illeistą ị kaminą. Toliau einant tiesiai ị paskutinị kambarị, arba kabinetą, durys dvivėrès fasuotos, dažytos baltai, su panašiais apkaustais. Tame kabinete langas toks pats vienas, sienos tamsios, ant vienos ju i ivairiomis spalvomis skoningai nutapytas peizažas, vaizduojantis jūros uostą, sienų viršuje [tapytas] karnizas, lubos dažytos rausvai. Krosnis kavos spalvos koklių, švediška, apšildanti du kambarius, su viengubomis geležinèmis durelèmis, panaši i ankstesnes. Grịžus ị aukščiau minètą vidurinị kambarị, iš jo (l. 4v) ị apvalią 
salę, įrengtą kupole, durys dvigubos fasuotos su tokiais pat apkaustais, joje švediška baltų koklių krosnis, viskuo panaši i pirmają, sienos su nišomis ir viršuje iškištas karnizas su dantukais iš plytų, o ant jo - pats kupolas, ištapytas ir papuoštas ịvairaus tipo rozetėmis, primenančiomis stiuko lipdybą. Iš tos salès ị rausvajị kambarị durys dvigubos su panašiais apkaustais. Iš to kambario tokios pačios durys einant ị aukščiau aprašytus laiptus, sienos dažytos rausvai su gražiu ištapytu karnizu ir frizu su triglifais; langų tokių pačių du, krosnis švediška, kavos spalvos koklių su geležinėmis dvigubomis durelėmis kaip ir ankstesnès. I paskutinị kambarị dvigubos durys su tokiais pat apkaustais, to kambario sienos dažytos pelenų spalva su gražiai nutapytu karnizu ir frizu; prie vienos sienos yra židinys; du langai tokie patys, dvivèriai. Visuose tuose kambariuose grindys stalių suklotos iš lentų, lubos iš kalkių ir gipso. Prie paties kupolo ant stogo kaminai visi plokšti, apkalti skarda, skarda ir gontai dažyti raudonai. To namo apačioje, žemėje - didelè mūrinè ledainė, pačiame jos centre sumūryta kvadratinė patalpa ledui sudèti, tik su vienu įejimu, tuo tarpu aplinkui ją - koridorius su lentynomis iš vienos ir kitos pusès alui pastatyti. Durys ị ją dvigubos, apkaltos lentelèmis, su didele prancūziška spyna ir dviem sklendėmis viršuje ir apačioje.

Senas kafenhauzas $^{22}$, pastatytas iš dvišonès medienos, iš kiemo pusès visas per vieną plytą apmūrytas, o viduje tinkuotas; i jị ịeinant durys i priemenę - dvivèrės, iš lentų, fasuotos, stalių darbo, viena jų pusè ant prancūziškų vyrių ir kablių, su šlosaku $u^{23}$, [priemenėje] lubos iš lentų, o grindys išklotos plytomis, virš durų apskritas skaidraus stiklo langelis mediniuose rèmuose sutvirtintas glaistu, kitoje priemenès pusejje skaidraus stiklo langas įrèmintas švinu su geležiniais virbais; praėjus užkaltas duris nuo oranžerijos pusès, toliau ị kambarị dešinèje pusejje dvivèrès staliaus darbo durys iš medinių skydų su prancūziškais vyriais, ant kablių, įleidžiama spyna su rankena ir raktu, šlosaku ir dviem sklendèmis; vienas skaidraus stiklo staliaus darbo langas mediniuose rėmuose, ittvirtintas glaistu, jo dvi dalys ant vyrių, kabliukų, su kampainiais, skląsčiais, kilpomis ir kabliukais; lubos iš lentų skylėtos, grindys lentinės. Baltų koklių krosnis, apšildanti du kambarius, (1. 5) sena, reikalinga remonto, mūrinis stačiakampis židinys, prie jo staliaus darbo uždanga iš lentų; vienvèrès staliaus darbo durys iš medinių

22 Šis iki mūsų dienų neišlikęs pastatas turejjo stovèti netoli dviejų aukštų mūrinio namo virš ledainès ir šiltnamių. Jis dar minimas $1803 \mathrm{~m}$. inventoriuje; $1803 \mathrm{~m}$. Verkių inventorius, 1. 258v.

23 Orig.: ślosak, slosak - tam tikras geležinis skląstis ar sklendè, detalè spynoje. Tiksli termino reikšmė nenustatyta. 
skydų, ant vyrių, jose įleidžiama spyna su rankena, raktu ir šlosaku; vienas langas toks kaip aukščiau aprašytame kambaryje, lubos ir grindys senos, lentinès. Einant toliau vienvėrès staliaus darbo durys iš lentinių skydų, dažytos pelenų spalva, ant vyrių, su kabliais, ịleidžiama spyna, rankena ir šlosaku, ị prieš tai buvusị kambarị, o prieš duris - mūriniai netinkuoti trijų pakopų laiptai; lubos iš lentų, grindys iš plytų; vienas didelis skaidraus stiklo langas mediniuose glaistu ịtvirtintuose rèmuose, stiklo lakštai dideli, su geležiniais kampainiais ir keturiais ratukais; nuo inspektų ${ }^{24}$ pusès kitas toks pats langas, krosnis baltų koklių dviems kambariams, mūriniai netinkuoti trijų pakopų laiptai prieš kambarị, ị kurị durys vienvèrès, staliaus darbo, iš lentų, dažytos pelenų spalva, ant kablių ir ilgų vyrių, su sugadinta įleidžiama spyna ir šlosaku; langas toks kaip kambariuose, aprašytuose aukščiau, lubos senos, supuvusios ir juodgrindès iš lentų; židinys užmūrytas; abiejuose šiuose kambariuose tinkas labai sugadintas; iš čia grị̌us ị priemenę durys prie laiptų i viršų vienvèrès, lentinių skydų, staliaus darbo, ant vyrių, su kabliais, illeidžiama spyna ir rankena, [vedančios] ị kambarį̣, kuriame vienas skaidraus stiklo langas švino rėmeliuose su geležiniais strypeliais, dvivėris, ant vyrių ir kabliukų, su kampainiais, skląsčiais, kilpomis ir kabliukais užkabinimui, prie to lango sudedamos dvigubos langinès iš lentų ant vyrių ir kablių, su geležiniu varžtu uždaryti, viduje lubos ir grindys iš lentų, krosnis baltų koklių, židinys stačiakampis ${ }^{25}$, durys dvivèrès iš lentinių skydų, staliaus darbo, ant vyrių ir kablių, su kabliuku ir kilpomis užkabinimui. Iš čia einant $\underset{i}{i}$ virtuvę atgal ta pačia priemene, kairėje pusėje durys vienvèrès iš lentinių skydų, staliaus darbo, dažytos baltai, ant trijų vyrių ir kablių, su illeidžiama spyna ir šlosaku, stakta iš vienos durų pusės apkalta juostelèmis, baltai dažyta, i prieš tai buvusią salę, kurioje trys dideli apskriti skaidraus stiklo langai su beveik viso dydžio stiklo lakštais (trys stiklai išdaužti), atsidarantys ị abi puses, ant prancūziškų vyrių, kiekviename turintys po dvi sklendes su kilpelėmis. Lubos, grindys iš plytų, (1. 5v) židinys stačiakampis,

24 Keista, kad šiame inventoriuje neaprašyti šiltnamiai, kurie jau tikrai buvo, tik prabėgomis paminèta oranžerija ir inspektai, buvę viršutinėje dvaro terasoje, netoli senojo medinio kafenhauzo. $1802 \mathrm{~m}$. duomenimis, tarp šiltnamių (trephauzu) buvo keturių dalių sodas, vienoje iš šių dalių buvo inspektai (1802-1806 m. Verkių dvaro inventorius, 1. 6). 1803 m. inventoriuje minimi trys mūriniai šiltnamiai - du didesni ir vienas mažesnis, aptverti bendra mūrine tvora, centriniame buvo ịrengtos ir vasarinės gyvenamosios patalpos (1803 m. Verkių inventorius, 1. 258v). Jie buvo toje pačioje vietoje, kur ir dabar stovi iš dalies išlikę du šiltnamiai, vienas jų su gyvenamosiomis patalpomis, taigi trečiasis turèjo stovèti ị pietus nuo jo. Dabar ị Kultūros vertybių registrą ịtraukti du šiltnamiai, vadinami oranžerijomis (kodai 24999 ir 2500), jie yra Žaliujų Ežerų g. 51.

25 Orig.: szafiasty. 
užmūrytas; aukštas mūrinis kanalas, jame skarda su rankena; uždegamas jis iš priemenės; siena iš fasado pusès tarp langų apkalta lentomis, stakta apkalta juostelėmis, iš vienos pusės dažyta baltai, be durų, jokių apkaustų, ị priemenę, kurios lubas reikia taisyti, grindys iš plytų, vienas didelis langas mediniuose rėmuoste, ịtvirtintas glaistu, skaidraus stiklo dideli lakštai, su kampainiais ir keturiais geležiniais ratukais nuo inspektų pusės, o staktoje keturi geležiniai kabliai. Toje pačioje priemenėje kairèje pusėje stakta su dviem kabliais ir šlosaku, be durų, ì kadaise buvusią smuklę, o joje mūriniai netinkuoti dvieju pakopų laiptai, vienas didelis langas nuo inspektų pusės, toks pats kaip aukščiau aprašytas, du langai mediniuose ir švino rèmuose, be aštuonių stiklų, i abi puses atsidarantys, su tokiais apkaustais, kokie aprašyti ankstesniuose kambariuose, lubos iš lentų, grindys iš plytų, krosnis žalių ir pilkų koklių, apšildanti du kambarius; mūriniai netinkuoti dviejų pakopų laiptai, stakta su dviem kabliais ir šlosaku, be durų i antrą kambarị, kuriame vienas skaidraus stiklo dvivèris langas švino rėmeliuose su geležiniais strypeliais, staliaus darbo rėmuose su kabliukais, ant vyrių, su kampainiais ir kabliukais; lubos ir juodgrindès iš lentų, židinys užmūrytas, vienvèrès lentinių skydų durys staliaus darbo, dažytos pelenų spalva, ant vyrių ir kablių, su paprasta įleidžiama spyna ir šlosaku, ị trečią kambarị, kuriame langas švino ir medžio rẻmuose toks kaip antrame kambaryje, su vienu išdaužtu stiklu; lubos ir juodgrindès iš lentų, o nišoje grindys iš plytų. Grịžus ị antrą kambarị paprasto darbo lentų durys ant ilgų vyrių ir kablių, su užsitrenkiančia rankena su spyruokle, su šlosaku ir antaba privèrimui, ị priemenę, kur ị mūrinę virtuvę yra lentinės dvivèrės staliaus darbo durys ant vyrių ir kablių, su įleidžiama spyna, rankena ir šlosaku, langas skaidraus stiklo staliaus darbo rėmuose, įtvirtintas švinu ir geležiniais strypeliais, su reikiamais apkaustais; priemenėje stalių darbo dvivèrès lentinių skydų durys ị kiemą (viena jų pusė visai sugedusi) ant vyrių ir kablių, su ileidžiama spyna ir rankena.

Austerija ${ }^{26}$ nauja, dviaukštè, mūrinè, nuo slabados pusès papuošta šešiomis kolonomis ir frontonu su karnizu iš tašyto akmens, išbalinta iš vidaus ir iš išorès pelenų spalva, jos stogas dengtas gontais (l. 6) ir dažytas raudonai, su trimis kolonomis - viena viduryje, o dviem šonuose - iškeltomis. 
Prie tos austerijos prijungtas kvadratu sumūrytas klojimas, viduje pagražintas medinėmis kolonomis, dviejuose sparnuose išgristas akmenimis, su gerai apkaustytais medinemis lentelèmis apkaltais vartais su tokiomis pačiomis durelèmis. Jos stogas taip pat dengtas gontais ir dažytas raudonai. Nuo slabados pusės įejjus i plytomis išgrịstą prieangi vartai austerijos priemenėje, esantys priešais vartus ị kiemą prieš senaji kafenhauza, mediniai, apkalti lentelėmis, su spynomis ir kitais reikiamais apkaustais, pro juos įèjus i priemenę dešinėje pusejje kafenhauzo namas, kurio durys fasuotos, iš lentų, ant kablių ir vyriụ, su ịleidžiama prancūziška spyna ir raktu bei rutuliu centre atidarymui, apačioje ir viršuje su dviem geležinėmis sklendèmis. Šio namo viduje yra keturi per pusę atsidarantys langai, turintys po dešimt didelių stiklo lakštų, su vyriais, turintys apkaustytus kampus ir sklendes; grindys išgrịstos molinėmis kvadratinėmis juodai išdegtomis plytomis, lubos tinkuotos, krosnis kvadratinė, baltų koklių, kūrenama iš priemenės, šone židinys su kryžmine duonkepe krosnimi ir du mediniai dvigubi lentelëmis apkalti staliaus darbo skydai. Iš šio namo durys ị mažą kambarèlį, kuriame lubos ir grindys panašios pirmiau aprašytoms, tokio paties dydžio langas, krosnis baltai glazūruotų koklių, apvali, pastatyta ant kryžminès krosnies. Kairẻje [nuo priemenės] pusėje smuklès kambarys, $i_{j} j \mathfrak{i}$ durys apkaustytos, langai, krosnis, plytu grindys ir lubos visai tokie pat kaip aprašytame kafenhauzo name, iš šio kambario durys ị kamarą su apkaustais ir spyna kaip aukščiau kambariuose aprašyta, kitos durys iš kamaros veda i priemenę, [kamaros] viduje švediška kvadratinė krosnis kavos spalvos glazūruotų koklių su apkaustytomis geležinėmis pakuros durelèmis; vienas langas su dešimčia didelių stiklo lakštų, apkaustytas; laiptai i viršų staliaus darbo su turẻklais, prie jų didelis dešimties didelių stiklo lakštų langas, sutvirtintas glaistu, užlipus laiptais aukščiau virš laiptų langelis iš keturių stiklo lakštų, ten pat dvivèrès lentelèmis apkaltos durys su spyna ir raktu, apkaustytos, vedančios i priemenę, kurioje nedidelis keturių stiklo lakštų langelis mediniuose rẻmuose. Iš tos priemenès tiesiai - salè, ị kurią durys dvivėrès, apkaltos lentelėmis, su vyriais, spyna ir raktu, apkaustytos, langas vienas, turintis aštuonis didelius stiklo lakštus, dvivėris, apkaustytas; (1. 6v) židinys su ventiliacijos anga ${ }^{27}$. Iš tos salès kairëje pusèje durys ị kambarị, 
dvivèrès, visos apkaustytos, su spyna ir raktu, tame kambaryje keturi langai, turintys po aštuonis stiklo lakštus, dvivèriai, apkaustyti; krosnies nėra. Mažas kambarys, ị kuri durys dvivèrès fasuotos, apkaustytos, su spyna ir raktu, jame pastatyta balta apvali krosnis, yra vienas apkaustytas aštuoniu stiklo lakštų langas, kitas langelis keturių stiklo lakštų. Iš šiu patalpų grịžus ị salę, iš jos i dešinę panašios patalpos, tai yra du kambariai, didesnis ir mažesnis, jų durys taip pat apkaustytos kaip ir kairèje pusèje, langai panašūs ir apkaustyti, krosnių dar nèra, vienos durys iš antro kambario išeinant ị priemenę dvivėrès fasuotos su spyna ir raktu, apkaustytos. Visuose tuose kambariuose ir priemenėje grindys iš lentụ, lubos tinkuotos, išeinant iš priemenès - mažos dvivèrès apkaustytos durelès su spyna ir raktu ị pastogę šienui sudèti. Grižus iš antro aukšto i̇ apačią laiptais ir atėjus ị aukščiau aprašytą austerijos priemenę, iš jos perẻjimas ị koridorių, kuriame yra vienos prieš kitas dvidešimt kolonų, [koridoriaus] gale mūrinè virtuvèlèè su geležies skardos viršumi, su rinkèmis; kitame gale tarp kolonų iš lentụ padaryta nedidelè kamarèlè malkoms sudèti su apkaustytomis durimis ir spyna. Einant nuo slabados vartụ i dešinę - klojimas, abiejuose klojimo galuose dvivèriai lentelèmis apkalti vartai su durelèmis, didelèmis ịleidžiamomis spynomis ir raktais, ant vyrių, apkaustyti. Viduryje grindys išgrịstos akmenimis, dvylika langų su stiklais mediniuose rèmuose, kiekviename po keturis stiklo lakštus, prikalti vinimis; dvidešimt šešios medinės kolonos, èdžios, iš lentų padarytos, ir grindys tarp kolonụ irrengtose vietose arkliams išklotos tokiomis pačiomis lentomis. Kitame klojime kairèje pusėje tokie patys dveji vartai abiejuose galuose, su tokiais pačiais apkaustais, spynomis ir raktais; kolonos, kartys su grandinèlemis ir geležiniais žiedeliais prie kiekvienos kolonos ir ėdžios, taip pat langai ir grindu išklojimas akmenimis ir lentomis panašu kaip pirmame klojime. Tuose klojimuose lubos iš kalkių ir gipso, tinkuotos. Kvadratinis kiemas tarp dviejų klojimų neišgrịstas, abipus klojimų viena prieš kitą dvi stoginès, turinčios po dvylika medinių kolonų, stogas virš jų, gontais dengtas, raudonai dažytas.

Namas, kuriame anksčiau gyveno ūkio raštininkas ${ }^{29}$, mūrinis, vieno aukšto, stogas senas, dengtas gontais, su vienu kaminu, išvestu virš stogo,

28 T. y. krosnis, viryklè.

29 Orig.: pisarz prowentowy. $1803 \mathrm{~m}$. inventoriuje šis namas apibūdintas kaip prūsiško mūro, dengtas gontais, su trimis kambariais ir rūsiu, jau apleistas; $1803 \mathrm{~m}$. Verkių dvaro inventorius, 1. $258 \mathrm{v}$. 
nuo kiemo pusės prieangis su dviem medinėmis kolonomis (1. 7), prieangyje grindys iš plytų, uždengtas taip pat gontais; iš jo tiesiai einant ị gyvenamajji kambarị durys vienvėrès fasuotos ant vyrių, kablių, su prancūziška spyna ir rankena; langų kambaryje trys, dvivėriai ant vyrių su geležiniais kampainiais, turintys po dvi sklendes viršuje ir apačioje; krosnis žalių koklių ir židinys prie jos; kitos durys tokios pačios ir su tokiais pat apkaustais i priemenę. Iš kambario ị alkierių durys su tokiais pat apkaustais, jame du tokie patys langai, sutvirtinti glaistu, iš kamaraitès durys į virtuvèlę, vienvėrès nefasuotos ant vyrių, kablių, su prancūziška spyna ir kabliuku su kilpele; langai tokie patys du; krosnis pilkų koklių, prie jos židinys valgiui gaminti. Kambaryje, alkieriuje ir virtuvejje grindys ir lubos iš lentų. Iš virtuvès i priemenę durys vienvėrès nefasuotos ant vyrių, kablių, su prancūziška spyna ir rankena. Iš priemenès į dešinę i tą vietą, iš kur pakuria krosnis, durys vienvèrès, senos, su vyriais, su nulenkiama geležine rankena, be kablių. Pačioje priemenëje grindys plytinès, lubos iš lentų, išeinant iš priemenès tik stakta su geležiniais kabliais, be durų i prieangi su medinėmis kolonomis, panašų i anksčiau aprašytajị. Po tuo namu mūrinys - nedidelis rūsys, ị kuri durys apkaltos lentelèmis, ant vyrių, kablių, su prancūziška spyna, raktu, skląsčiu, kilpomis ir geležine antaba. Tame rūsyje mažas langelis su geležinèmis grotomis.

Svirnas pastatytas iš dvišonių tašų ant mūrinių pamatų, trijų aukštụ, stogas gontais dengtas, įeinant i jị durys dvivėrès apkaltos lentelëmis, ant vyrių, kablių, su prancūziška spyna ir rankena, apačioje ir viršuje su dviem geležinėmis sklendėmis. Priemenėje grindys iš lentų, kairẻje pusėje i pirmą sandèli durys vienvèrès su prancūziška spyna, ant vyriụ ir kablių. Siauros langinès, kiekviena ant dviejų antabų, su viena geležine sklende, atsidarančios i apačią, dvi. Grindys iš lentų. Iš tos priemenès ị dešinę i kamarėlę mažą su aruodu druskai supilti durys vienvėrès ant vyrių ir kablių, su prancūziška spyna. Langas aklinai užkaltas lentomis. Iš tos priemenès tiesiai einant ị antrą, didesni, sandèli durys vienvèrès ant vyriu ir kablių, su prancūziška spyna; grindys iš lentų, langinès su tokiais pačiais apkaustais, dvi. Pačioje priemenėje ąžuolinis velenas su trimis tokiomis pačiomis kartimis grūdams užkelti, apkaltas dviem geležiniais žiedais, vienas galas 
su keturiais išilginiais geležies strypais, kur pritvirtintos kartys, jų galuose (l. 7v) du dideli geležiniai kaiščiai ir dvi geležies detalès, prikaltos prie sienos, kur kaiščiai apsisuka. Dešinėje pusėje mediniai laiptai su posūkiu, ju viduryje maža langinė su apkaustais; užlipus ị antrą aukštą kryžminiame koridoriuje po kaire, kur praeina keltuvo lynas, senos vienvėrès gulinčios durys ant vyrių ir kablių, ten pat mažas aruodas javams, koridoriuje trys tokios pačios langinès; dešinèje pusejje sijomis atitverti du didesni ir vienas mažesnis aruodai, dvi tokios pačios langinès, grindys ir sienos iš lauko pusès lentomis užkaišytos. I trečią aukštą laiptai taip pat su posūkiu, jų viduryje sienoje viena langinė. Užlipus ị viršų kryžminis koridorius panašus i pirmajị, čia trys didesni aruodai, mažas vienas, atitverti sijomis. Grindys aruoduose ir koridoriuose iš lentų sukaišytos, sienos taip pat aplinkui lentomis apkaltos, tame aukšte iš viso šešios langinès. Einant i pastogę laiptai su posūkiu, pastogėje medinis kabas su geležine ašimi, prie kurio prikabintas keltuvo lynas. Sienoms sutvirtinti yra aštuoni mediniai strypai, prie šešių iš jų yra dvidešimt keturios geležinès templès, prie dviejų - šešios. Prie šito svirno iš lentų padaryta ir lentomis uždengta šuns būda.

Svirnas tokios pat formos antras, gontais dengtas, durys vienvèrès, apkaltos lentelèmis, ant vyrių, kablių, su prancūziška spyna, ị priemenę, joje dešinėje pusėje atitvertas sandèliukas medienai sudėti, su vienvèrèmis durimis ant vyrių ir kablių, su prancūziška spyna. Langas aklinai užkaltas lentomis. Atitvaras, kaip ir grindys, iš lentų. Kairëje pusėje ị antrą priemenę durys taip pat vienvėrès nefasuotos ant vyrių ir kablių, su prancūziška spyna, joje vienas didelis langas su stiklu mediniuose rèmuose, grindys iš lentų; kitos įėjimo durys apkaltos lentelèmis, vienvèrès, ant vyrių ir kablių, su prancūziška spyna, skląsčiu, kilpelèmis, viduje su sklende ir antaba geležinėmis; iš tos priemenės ị dešinę didelis svirno sandèlis, kurio viduryje tarp stulpų iš lentų įrengtas didelis aruodas, padalytas ị dvi dalis, aplink ji koridorius, grindys taip pat iš lentų suklotos, langinių su tokiais pačiais apkaustais septynios. Grị̌zus i pirmają priemenę, iš jos laipteliai i antrą aukštą, kur panaši priemenè su kamara dešinėje pusèje, atitverta lentomis, be durų, tuo tarpu einant tiesiai ị kairę vienvèrès durys ant vyrių, kablių, su prancūziška spyna; čia pačiame centre aruodai (1. 8) grūdams supilti, du didesni ir du 
mažesni, grindys iš lentų suklotos, aplinkui langinės su vienodais apkaustais septynios. Iš ten ị trečią aukštą mediniai laipteliai, į kuriuos einant gulinčios durys ant vyrių, kablių, su skląsčiu ir kilpomis, trečiame aukšte taip pat viduryje iš lentų padaryti du didesni ir du mažesni aruodai grūdams, grindys ir lubos iš lentú, aplinkui septynios langinès su vienodais apkaustais; tame pačiame aukšte kairẻje pusėje [durys] į nedideli sandèlį, iš kurio veda laiptai i pastogę, čia yra viena langinè su apkaustais, aruodai iš mūrtašiu ir lentų miltams ir kt. devyni, iki pusės uždengti lentomis; virš perdengimo po pačiu stogu tarp dviejų stulpų yra ratas su velenu grūdams i viršų kelti. Sienoms sutvirtinti keturi mediniai statramsčiai, prikalti medinėmis vinimis.

Namas $^{30}$ dviaukštis, mūrinis, ką tik aprašyto svirno gale, ị ji ịeinant - priemenè, durys dvivèrès fasuotos ant vyrių, kablių, su dviem skląsčiais bei nulenkiama rankena. Virtuvèlè toje pačioje priemenėje, jos grindys iš dalies iš plytų, iš dalies iš lentų sudètos; dešinèje pusejje durys i gyvenamaji kambarị, vienvèrès, fasuotos, ant vyrių, kablių, su prancūziška spyna, jame penki dvivėriai langai, ittvirtinti glaistu, ant vyrių, kabliu, su kampainiais bei kiekvieno viršuje ir apačioje dviem sklendèmis; krosnis pilkų koklių, sena, prie jos židinys; grindys ir lubos iš lentų; kitos durys iš to kambario ị priemenę, fasuotos, ant vyrių, kablių, su prancūziška spyna. İẻjus i priemenę kaip anksčiau, kairẻje pusẻje - durys i kitą gyvenamajji kambarị, vienvėrès, fasuotos, ant vyriụ, kabliụ, su prancūziška spyna ir rankena; jame trys dvivèriai langai, itvirtinti glaistu, su tokiais pat apkaustais; krosnis žalių ir baltų koklių, prie jos židinys su karnizu. Iš šio kambario ị kamarą durys taip pat fasuotos ant vyrių, kablių, su prancūziška spyna ir rankena; joje du tokie patys langai, kryžminė duonkepè krosnis. Toje kamaroje senos vienvèrès durys ị mūrinị rūsị, gulinčios ant vyrių, kablių, su skląsčiu ir kilpomis. Kambaryje bei kamaroje ir grindys, ir lubos sudètos iš lentų. Iš tos kamaros išeinant ị priemenę durys vienvėrès fasuotos ant vyrių, kablių, su prancūziška spyna ir rankena, o iš priemenès ị kitą namo pusę išeinant dvivèrès fasuotos durys (1. $8 \mathrm{v}$ ) su išpjautais dviem langeliais, be stiklo, ant vyrių, kablių, su dviem geležinėmis sklendėmis viršuje ir apačioje, su prancūziška spyna ir rankena; iš tos priemenès einant suktais laiptais su turèklais ị antrą aukštą, virš laiptų yra vienas ovalus langas, ịtvirtintas 
glaistu; [užlipus] dešinėje durys ị priemenę vienvèrès ant vyrių, kablių, su nulenkiama rankena ir antaba; toliau einant ị antrą tokią pat mažą priemenę tik stakta su kabliais, be durų, iš priemenès dešinėje durys ị gyvenamąjị kambarị vienvèrès nefasuotos ant vyrių, kablių, su prancūziška spyna ir rankena; trys ovalūs langai, îtvirtinti glaistu, viename jų vieno stiklo lakšto orlaidė ant vyrių, su kabliuku užkabinimui; krosnis kavos spalvos koklių ir židinys prie jos. I kamarą durys vienvėrès fasuotos ant vyrių, kablių, su prancūziška spyna ir rankena, joje du tokie patys langai. Kairèje pusèje iš priemenės i kitą gyvenamaji kambari durys taip pat vienvėrès nefasuotos ant vyrių, kablių, su prancūziška spyna ir rankena; langų jame tokiu pačiu keturi, krosnis didesne dalimi baltų koklių, maža dalimi - kavos spalvos koklių, prie jos židinys, panašus i pirmaji; i kamarą durys fasuotos ant vyrių, kablių, su prancūziška spyna ir rankena, joje du tokie patys langai. Išèjimui ị laiptus durys tokios pačios vienvėrès ant vyrių, kablių, su prancūziška spyna ir rankena. Priemeneje, kambaryje ir kamaroje tiek grindys, tiek ir lubos iš lentų. Tas namas pastatytas su karnizu, turi laužtą stogą, dengtą gontais, su dviem virš stogo iškeltais mūriniais kaminais.

Arklidė prūsiško mūro ${ }^{31}$ su karnizu ir kronšteinais, didelè, jos stogas dengtas čerpėmis, reikalingas remonto; abiejuose tos arklidès galuose dvi vežiminès su mediniais ịvažiavimo tiltais. Dešinėje fasado pusėje i pirmają vežiminę dveji dideli dvivèriai lentelėmis apkalti vartai, prie ju yra dvylika porų vyrių; prie vienu [vartų] didelis rygelis su rankena ir kilpomis užrakinti pakabinama spyna, apačioje skląstis su kilpomis; iš vidaus prie vienos varčios kabliukas su kilpomis užkabinimui; prie kitų vartų iš vidaus pusès panaši pirmajai velkė ir kablys su kilpomis užkabinimui; grindys ir lubos iš lentų. Kairèje fasado pusėje ị antrą vežiminę dveji dideli dvivèriai lentelèmis apkalti vartai, prie jų dvylika porų vyrių, prie vienų didelẻ velkẻ su skląsčiu (1.9) ir kilpomis, prie kitų taip pat velkè ir kabliukas su kilpomis užkabinti iš vidaus; grindys ir lubos iš lentų. Centre ị pačią arklidę tiltelis, grịstas akmenimis, juo einant dvivèriai lentelèmis apkalti vartai, prie ju šešios poros vyriụ, didelè velkè su kilpomis iš vidaus, vartuose durelès, taip pat apkaltos lentelèmis, ant vyrių, kablių, su sklassčiu ir kilpomis; grindys ir lubos iš lentų. Pereinant ị kitą arklidès pusę vartai, apkalti lentelèmis, 
viskuo panašūs ị pirmuosius, prie durelių gi antra velkė su kabliukais ir kilpomis užkabinimui. Kairèje pusėje iš priemenès i pirmają arklidę vartai, lentomis užkalti, juose paprastos dvivèrès lentų durys ant vyrių, kablių, su dviem skląsčiais ir kilpomis; arklidejje paprastos èdžios su kopėčiomis; abipus yra gardai ${ }^{32}$ arba kolonos dvidešimt keturiems arkliams, kartelių su grandinėmis yra tik penkios, gi žiedai kartelèms yra tiek prie visų kolonų, tiek ir prie èdžių. Stiklo langų, įtvirtintų glaistu, dešimt. Grindys ir lubos iš lentų; gale ant mūro nutapyta kaskada. Dešinėje pusėje iš priemenès ị kitą arklidę vartai taip pat užtverti lentomis, juose paprastos dvivėrès lentų durys ant vyrių, kablių, su skląsčiu ir kilpomis užrakinimui kabančia spyna; ši arklidė skirta iškilmingesniems žirgams, jų telpa taip pat dvidešimt keturi, abiejose pusėse kartys arba gardai, visų vienas galas prikaltas stambiomis vinimis prie kolonų, kitas - prie mūro; garduose prieš kiekvieną žirgą vietoj èdžių yra staliaus darbo skrynutès avižoms, o virš jų prie sienos stambiomis vinimis prikalti krepšiai šienui; kiekviename garde yra po penkis geležinius žiedus arkliams pririšti; langų tokių pačių dešimt; grindys ir lubos iš lentų.

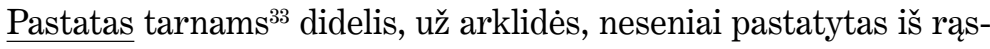
tų, iš dviejų šonų aptašytų, jo stogas dengtas skiedromis, su dviem virš stogo iškeltais kaminais; to pastato viduryje priemenè, ì kurią ieinant vienvėrès durys ant vyrių su nulenkiama rankena ir antaba; per priemenę einant i kitą pastato pusę - vienvèrès durys su tokiais pačiais apkaustais, dešinėje pusėje - durys ị pirmą gyvenamajj kambarị taip pat vienvėrès ant vyrių, kablių, su nulenkiama rankena ir antaba bei skląsčiu ir dviem kilpomis; (1. 9v) kryžminė duonkepė krosnis su skardiniu krosniakaiščiu, keturi dideli langai mediniuose rèmuose, viename iš jų atidaroma orlaidè. Toje pačioje pusėje i antrą gyvenamaji kambarị vienvèrès durys ant vyrių, kablių, su nulenkiama rankena ir antaba bei su dideliu skląsčiu ir tik viena kilpa; kryžminė duonkepė krosnis iš plytų su krosniakaiščiu. Langai tokie patys, mediniuose rèmuose, keturi, vienas iš jų su orlaide. Priemenės kairèje, nuo arklidès pusès, $\underset{t}{i}$ trečią gyvenamajji kambarị durys taip pat vienvèrès ant vyrių, kablių, su nulenkiama rankena, antaba, kabliuku ir dviem kilpomis užkabinimui; duonkepė kryžminè krosnis, mūryta iš plytų, su krosniakaiščiu ir skardiniu dangčiu krosnies angai uždengti; langų tokių pačių keturi,

32 Gardai žirgams buvo atskiriami ant grandinių kabančiomis kartelëmis.

33 Orig.: czeladny. Pastatas minimas ir 1803 m., tik buvo dengtas šiaudais; 1803 m. Verkiu dvaro inventorius, 1. 259. 
viename atsidaranti orlaidė. Toje pačioje linijoje ị ketvirtą gyvenamajji kambari durys vienvėrès ant vyrių, kablių, su nulenkiama rankena ir antaba bei su kabliuku ir dviem kilpomis užkabinimui; duonkepė kryžminẻ krosnis, sumūryta iš plytų, su krosniakaiščiu. Langai tokie patys, trys. Visuose kambariuose grindys plūktos moliu, lubos iš lentų. Už šio pastato iš apvalių rąstų pristatyta maža kamarèlè, dengta skiedromis, jos durelès mažos, ant bėgūnų, su skląsčiu, dviem kilpomis ir geležine antaba.

Tvartai nedideli du, tarp jų maža arklidè, pastatyta iš apvalių rąstụ, ịprastai uždengta šiaudais, ị pirmą tvartelị dideli vartai iš lentų ant bègūnų, prie šulo prikalta viena geležinè antaba; kitame gale ị antrą tvarteli durys vienvėrès ant bėgūnų. Per vidurị arklidè keturiems arkliams su ėdžiomis; juodgrindės iš lentų, durys i ją vienvèrès ant vyrių, kablių, su skląsčiu ir kilpomis.

Skerdykla tarp šių tvartelių ir didžiosios arklidès ${ }^{34}$, sena, pastatyta iš apvalių rąstų, dengta šiaudais; jos durys iš lentų, ant vyrių, kablių, su skląsčiu ir kilpomis spynai pakabinti; viduje juodgrindès iš lentų, jose yra gulinčios durys ant vyrių ir kablių, nešvarumams išmesti.

Stoginè medienos žaliavai sukrauti, toliau už slabados, didelè, pastatyta iš statinių tarp šulų, dengta šiaudais „po lopeta“, viršuje stogas vejjų truputi apdraskytas, nuo kelio pusės ị stoginę (l.10) dideli dvivėriai vartai iš lentų, kuriuose vietoj bėgūnų yra keturi geležiniai kaiščiai, ịkaltos ị šulą dvi didelès geležinės detalès, kuriose viršutiniai kaiščiai apsisuka, prie vienos vartų pusės dviem geležiniais varžtais pritvirtinta kartis, prancūziška spyna su rankena ir dviem kilpomis tai karčiai prirakinti; kitame stoginės gale, nuo miško pusès, tokie patys dvivèriai vartai iš lentų su tokia pačia spyna ir kitais apkaustais, šonuose dveji vartai lentomis aklinai užkalti, viduje vienoje puseje iš lentų padarytos èdžios statybų arkliams.

Antra stoginè, dar toliau einant, ant stulpų, stogas skiedromis dengtas, labai senas, viduje dvi iš plytų sumūrytos krosnys kalkių akmenims degti.

Malūnas $^{35}$, einant nuo rūmų kiemu žemyn link tvenkinių supiltu keliu, pasukus ị kairę - supiltas pylimas su mediniu tiltu ir šliuzu iš rąstų, turinčiu vožtuvą su geležine ašimi ir šešiais geležiniais virbais, prie jo, kad 
būtų šviesiau, iš abiejų pusių yra dvejos geležinės grotos, ten pat yra vamzdis, išmetantis vandenị ant rato. Prie to pylimo malūnas, arba machina, su vienu dideliu vandens ratu, sukančiu iš karto du akmenis, pastatytas iš medinių rąstų, dažytas pelenų spalva, stogas, gontais dengtas, dažytas raudonai. Iš priekio prieangis su keturiais laiptais, išgrịstas rąstais, su lubomis viršuje ir lentų juodgrindėmis, su šešiomis medinėmis kolonomis ir turèklais iš baliustrų galuose. Durys ị malūną staliaus darbo dvivèrès, apkaltos lentelèmis, geležinėmis vinimis, ant keturių ilgų vyrių ir kablių, su įleidžiama didele spyna, šaltkalvio darbo raktu ir dviem geležinėmis sklendèmis; du langai balto stiklo, ị abi puses atsidarantys, staliaus darbo rèmuose, ant vyrių, kablių, su sklendėmis, kampainiais ir šlosakais; dvejos langinès staliaus darbo, ant ilgų vyrių su keturiais kabliukais ir aštuoniomis kilpomis užkabinimui; mūrinis kaminas iškeltas virš stogo; grindyse dvi angos pilti grūdus ị pintines. Lubos iš lentų nebaigtos; kitos durys staliaus darbo iš lentų, apkaltos lentelèmis ir geležinėmis vinimis, ant ilgų vyrių ir kablių, su prancūziška spyna, raktu, rankena ir šlosaku; pro jas išèjus, (1. 10v) kitoje malūno pusèje, galerija, išklota lentomis, išilgai jos turèklas iš tekintų, pelenų spalva dažytų baliustrų, galuose prisijungiančių prie rąstų sienos. Ta galerija skirta plaunamiems kviečiams džiovinti. Iš to aukšto prie akmenų ir pintinių vedantys mediniai laiptai su baliustrų turèklais; nusileidus kairèje pusėje pirmos durys vienvèrès, staliaus darbo, ant vyrių, kablių, su prancūziška spyna, raktu bei šlosaku, ịejjus pro tas duris yra vieta, kur iš vamzdžio vanduo krenta ant rato; einant pro vamzdi - antros durys iš lentų vienvèrès, staliaus darbo, ant dviejų vyrių, kablių, su prancūziška spyna, raktu, rankena ir šlosaku, i pirmą priemenę, kurios lubas sudaro viršutinės patalpos juodgrindès, grindų nèra, prieš ją maži mediniai laipteliai; iš tos priemenès i kairę, i pirmą kambarị, durys iš lentų vienvèrès; jame du balto stiklo langai, atsidarantys ị abi puses, stalių darbo rėmuose, ant vyrių, kabliukų, su sklendèmis, kampainiais ir šlosakais; mūrinys - židinys jungiasi su kaminu, esančiu viršuje, kavos spalvos koklių krosnis, apšildanti du kambarius, lubos ir grindys iš lentų; tame kambaryje grindyse gulinčios durelès iš lentų, ant vyrių, kablių, su geležiniu žiedeliu, po jomis mediniai laiptai, vedantys žemyn, prie mūrinių pamatų; šių laiptų gale dar vienvèrès durys iš lentų, 
ant vyrių ir kablių, i vietą, kur yra vandens ratas; iš kitos pusės toks pats iẻjimas prie tų pamatų; pamatai mūriniai, ant kurių guli galas veleno, prakišto per pagrindinès sienos mūrą; viršuje siauras balto stiklo langas staliaus darbo rèmuose be apkaustų, už jo yra geležinès grotos. Grị̌us ị pirmąji kambarị vienvèrès durys iš lentinių plokščių staliaus darbo, ant vyrių, kablių, su prancūziška spyna ir šlosaku, ị antrą kambarị, kuriame trys balto stiklo langai, atsidarantys ị abi puses, ant vyrių, kablių, su sklendèmis, kampainiais ir šlosakais; mūrinis židinys su ūkiška mūrine krosnimi, iškišta ị antrają priemenę ir sujungta su židiniu viršuje; lubos ir grindys iš lentų, vienvèrès staliaus darbo durys iki pusės ịstiklintos, ant vyrių, kablių, su ịleidžiama prancūziška spyna, raktu ir šlosaku, ị aukščiau paminètą antrają priemenę, kurioje lubos iš lentų, grindų nèra; čia kairèje pusėje vienvėrès staliaus darbo durys (1. 11) iš lentų, iki pusès įstiklintos, ant dviejų vyrių, kablių, su prancūziška spyna, rankena bei šlosaku, ị trečią priemenę, kurioje lubos iš lentų, grindų nèra; ši priemenė pertverta neobliuotomis lentomis, su paprastomis durimis ant ilgu paprastų vyrių, su rankena pakabinamai spynai; taip pat išeiti už malūno durys iš lentų vienvėrès, staliaus darbo su prancūziška spyna, rankena, raktu ir šlosaku, ant ilgu paprastų vyrių ir kablių, prie šių durų vienas balto stiklo langas, atsidarantis $\underset{\mathfrak{i}}{\mathfrak{i}}$ abi puses, ant vyrių, kabliukų, su sklendèmis, kampainiais ir šlosakais. Iš čia grịžus į antrą priemenę - vienvèrès durys staliaus darbo, iki pusės ịstiklintos baltu stiklu, ant dviejų vyrių ir kablių, su nulenkiama rankena, antaba ir kabliuku su kilpomis užkabinimui, ì pirmą priemenę, o iš ten nuejjus iki antrų aukščiau aprašytų durų i tą patalpą, kur yra vamzdis, dešinèje pusėje ant juodgrindžių suoliukas su nugaros atrama iš lentų, o už jo, vamzdžio gale, po galerija, mažos durys iš lentų ant ilgų paprastų vyrių ir kablių su dviem kabliukais ir keturiomis kilpomis užkabinimui bei dvejomis geležinėmis grotomis virš durų ir po jomis; kairèje gi pusėje, iškirstoje sienoje, kur nuteka vanduo, abiejose pusėse yra dvejos durelès iš lentų, paprasto darbo, vienos iš jų be apkaustų, kitos ant paprastų ilgų vyrių, su kabliuku ir kilpelèmis užkabinimui, už šių durų du vamzdžiai iš smala aplietų sijų, [einantys] nuo tvenkinio net po galerija, vienas iš jų skirtas vandeniui leisti ant malūno rato, turi užtvarèlę ant dviejų vyrių su keturiomis veržlèmis ir ilgu virbu tai užtvarèlei

$97-2020$

Acta Academiae Artium Vilnensis 
pakelti viename gale apkaustytu keltuvu, perkištu per malyklos ${ }^{36}$ sieną, kitas turi išpjautą skylę pertekliniam vandeniui nuleisti. Iš čia nuejjus už pirmų, aukščiau minètų, durų, kur vamzdis ir malykla, ten netoli dviejų kolonų yra pakyla, ant jos ant postamentų stovi du mediniai kubilai su keturiais akmenimis, dvi staliaus darbo pintinės su dangteliais, iš kurių išbyra grūdai ant akmenų; dvejos apkaustytos svarstyklės akmenims pakeltii ir nuleisti, su dviem geležiniais strypais; nuo tos pakylos mediniais laiptais nusileidus truputi žemiau yra mažos, paprastos lentinès durelès ant paprastų ilgų vyriu su dviem kabliukais ir dviem kilpelèmis užkabinimui, [jos veda] po ta pakyla, kur ant dviejų geležinių velenų yra du mediniai krumpliaračiai (̌̌šstarnès) su keturiais geležiniais lankais (1. 11v) ir apkaustytais kampais pikliui kratyti. Šalia dantračio ant stovinčio veleno du stulpeliai su dešimčia geležinių lankų pikliui. Geležinis ventiliatorius apvaliame staliaus darbo kubile su ilgu tokio pat darbo vamzdžiu smulkiausiems miltams vėdinti. Siauras balto stiklo langas be apkaustų staliaus darbo rẻmuose, už jo geležinès grotos. Laiptai iš lentų ị apačią, prie mūrinių pamatų, kur lentų durys vienvẻrès staliaus darbo ant dviejų vyrių ir kablių, i̇ tą vietą, kur yra malūno ratas; viršuje mažas balto stiklo langas staliaus darbo rẻmuose, be apkaustų, už jo geležinės grotos. Krumpliaratis (šeštarnè) didelè su geležiniais lankais su vienu geležiniu velenu, su vienu keturkampiu apkaustu ant to paties stovinčio veleno, ant kurio yra viršutinis dantratis; taip pat dantratis ant vandens rato volo. Iš čia grịžus atgal, minètoje malykloje prie pakylos dvi didelès lentinès staliaus darbo skrynios ant kojelių su dangčiais; prie jų du volai su medinėmis ir geležinėmis detalèmis praleisti miltus, išeinančius iš po akmenų; staliaus darbo pakyla iš lentų su durelèmis ant ilgų paprastų vyrių ir kabliuku su kilpomis užkabinimui, vedančiomis ten, kur miltai pikliuojami; toje pačioje malykloje yra keturi balto stiklo langai, atsidarantys i abi puses, staliaus darbo rėmuose, ant vyrių, kabliukų, su sklendemis, kampainiais ir šlosakais, vienas langas užkaltas; lubos ir pakyla iš lentų. Iš malyklos ị prieangị durys iš lentų, dvivèrès, staliaus darbo, ant vyrių, kablių, su prancūziška spyna, rankena ir šlosaku, jose vienas balto stiklo langas staliaus darbo rėmuose, ant vyriukų, kabliukų, su sklendėmis, kampainiais ir šlosaku; lubos ir juodgrindès iš lentų. Paskutinès durys ị malūno 
užnugarị, jos staliaus darbo, iš lentų, vienvėrès, ant vyrių ir kablių, su prancūziška spyna, raktu, rankena ir šlosaku, iš ten einant šalia kalno, kuris lieka kairèje pusėje, ir pasukus ị dešinę žemyn iki lentomis sutvirtinto kaklo, tarp aukščiau aprašytų mūrinių sienų yra didelis vandens ratas, po malūno pastatu sukantis kartu du akmenis ir turintis dvidešimt keturias geležines ašis su veržlëmis ir ant volo aštuonis geležinius lankus bei du didelius kaiščius. Iš trijų malūno pusių eina iškasti ir rąstais sutvirtinti kanalai vandeniui nutekèti. (1. 12)

Arklidė tarp malūno ir apynyno, pastatyta iš medienos, aptašytos iš dviejų šonų, su trimis aukštomis sienomis, tarp kurių ant ketvirtos žemesnès sienos į užnugarị nuleistas stogas, dengtas šiaudais, i ją vartai dvivėriai ant geležinių vyrių ir kablių, vienoje durų pusèje baslys, o prie staktos geležinis klemeris ${ }^{37}$ su kilpomis užrakinimui pakabinama spyna.

Namas didelis, vadinamoji garbarnè $\dot{e}^{38}$, prie mažesnio tvenkinio netoli malūno, pastatytas prūsišku mūru. Ten gyvena račius Antanas Hovaras $(\text { Howar })^{39}$. Namo stogas laužtas, senas, dengtas gontais, reikalingas esminio remonto, virš jo yra išvesti trys kaminai. İeinant ị priemenę nuo kelio pusės durys iš lentų, senos, dvivèrès, ant vyrių ir kablių, su dviem antabomis uždarymui basliu, jose durelès ant vyrių, kablių, su velke, su nulenkiama rankena, su kabliuku užkabinimui ir kilpomis; priemenėje trys langai, ittvirtinti glaistu, juose šeši stiklai išdaužti; priemenẻ išgrịsta akmenimis; virtuvėlẻ ten pat, kamine, su plytine duonkepe krosnimi, i ją durys senos, vienvėrès, ant vyrių, kablių, su skląsčiu ir kilpomis; šalia tos virtuvèlès ir tame pačiame kamine kadaise išmūrytas kalvio žaizdras ${ }^{40}$ su dvejomis dumplèmis. Iš šios priemenės einant ị kitą pastato pusę - senos vienvėrès durys ant vyrių, kablių, su velke, užstūmiamos basliu, tose duryse durelės ant vyrių, kablių, su nulenkiama rankena, su skląsčiu ir kilpomis, pro jas įejjus i antrą priemenę, arba račiaus dirbtuvę, joje yra keturi langai, sutvirtinti glaistu, juose dvidešimt šeši išdaužti stiklai; penktas mažas langelis virš tekinimo staklių, jame išdaužti du stiklai; grindų dvi dalys iš lentŭ, trečia dalis išpilta smèliu; lubos iš lentų, paremtos mūriniu stulpu; i nišą, kurioje maža virtuvèlè ir iš kurios kūrenama krosnis, senos, didelès vienvėrès durys ant vyrių, kablių,

37 Klemeris - (vok. Klammer, lenk. klamra) - pritvirtinimas, užkaištis durims uždaryti, geležinè sankaba.

38 Odų raugykla, odų gaminimo dirbtuvè.

39 Račiaus Antano Hovaro namas toliau minimas ir Naujujų Verkių kaime.

40 Orig.: horno. 
su kabliuku ir kilpelèmis užkabinimui. Iš tos dirbtuvės pereinant ị kitą pastato pusę - vienvèrès mažos durys ant vyrių, kablių, su skląsčiu ir kilpomis. I gyvenamajị kambarị durys senos, vienvèrès, fasuotos, su trimis poromis vyrių, prancūziška spyna, rankena ir raktu, kambaryje trys langai, įtvirtinti glaistu, dvylika stiklų išdaužta; krosnies pusė iš plytų, o pusė iš pilkų koklių, (l. 12v) ji apšildo kambarị ir kamarą, prie jos židinys su durelėmis ant vyrių, kabliuku ir kilpelèmis; grindys ir lubos iš lentų. I kamarą geros vienvėrès durys su dviem poromis vyrių, prancūziška spyna su rankena ir raktu; joje du didesni langai, trečias mažesnis, ịtvirtinti glaistu, keturi stiklai išdaužti; grindys iš plytų, lubos iš lentų. Iš šios kamaros i priemenę senos fasuotos durys su trimis poromis vyrių, paprasta sugadinta spyna. Už namo iš senų lentų padarytas mažas tvartelis, kurio durelès ant vyrių, kablių, su skląsčiu ir kilpomis. Kairèje pusėje iš pirmos išgrịstos priemenės, t. y. kitoje šio pastato pusėje, ì gyvenamaji kambarị dvivèrès fasuotos durys ant vyrių, kablių, su prancūziška spyna, rankena joje ir raktu bei su geležine užsilenkiančia rankena; trys sveiki langai mediniuose rèmuose, plytinẻ krosnis, apšildanti kambarị ir kamarą, prie jos židinys; grindys ir lubos iš lentų; i kamarą vienvèrès durys ant vyrių, kablių, su prancūziška spyna, raktu ir rankena; du sveiki langai mediniuose rèmuose; grindys iš plytu, lubos iš lentų; šalia krosnies durys i priemenę senos, vienvèrès, fasuotos, ant lenktų vyrių ir kablių, su nulenkiama rankena ir kilpomis; iš tos pačios kamaros i sandèli didelès vienvėrès durys ant vyrių, kablių, su prancūziška spyna ir rankena bei raktu; jame vienas langas mediniuose rèmuose, du stiklai išdaužti; langinès iš vidaus ant vyrių, kablių, su geležine sklende ir kilpomis; grindys ir lubos senos, iš lentų. Iš sandèlio ị tą pačią priemenę vienvėrès durys ant vyrių, kablių, iš vidaus su skląsčiu ir kilpomis. Visame tame pastate vienpusių langinių septynios, dvigubų dvi, ant vyrių, kablių, su geležiniais strypais uždarymui. Už pastato iš nugarinės pusès, šalia tvartelio, nedidelis rūselis iš lentų, apgriuvęs, ị jị vienvèrès durys ant vyrių, kablių, su skląsčiu ir kilpomis; ten pat kiemelis, aptvertas apgriuvusia medine tvora; prie jos iš vidinès pusès:

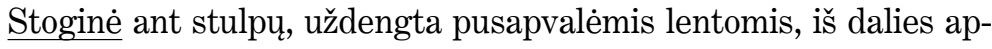
griuvusi. Dabar tuščia. 
Nuo to namo einant link miestelio ant kalvos dešinėje kelio pusėje:

1-as namas, dviaukštis, ant mūrinių pamatų, pastatytas iš tašų, stogas, gontais dengtas, su vienu kaminu, išvestu virš stogo; jo fasade prieangis su frontonu, papuoštas šešiomis kolonomis, jame grindys ir lubos iš lentų. Iš prieangio einant ị priemenę (1. 13) - dvivèrès, lentelëmis apkaltos durys ant vyrių, kablių, su prancūziška spyna ir rankena, su dviem viršuje ir apačioje sklendėmis; priemenėje virtuvèlè iš plytų ir grindys tokios pačios, dvivėris langas, itvirtintas glaistu, ant vyrių, kablių, su kampainiais ir dviem skląsčiais iš vidaus pusės; iš priemenès einant tiesiai - durys i gyvenamaji kambarị vienvėrès, staliaus darbo, nefasuotos, ant vyrių, kablių, su prancūziška spyna ir rankena; kryžminė duonkepè krosnis iš plytų, kita krosnis švediška, kavos spalvos koklių, su dvigubomis geležinėmis durelèmis bei tokiu pačiu krosniakaiščiu; trys maži langai, ittvirtinti glaistu, ant vyrių, kabliukų, su kampainiais ir prie kiekvieno skląsčiais iš vidaus pusės; grindys iš plytų, lubos iš lentú. I kamarą durys tokios pačios kaip ị kambarį, su tokia pačia spyna ir apkaustais, langai joje tokie patys du, židinys iš plytų, virš jo yra keliolika kavos spalvos koklių, sudètų krosnies forma. Iš čia ị mažesnę kamarèlę tokios pačios durys ant vyrių ir kablių, be spynos, langas toks pats vienas. Kamarose, didesnėje ir mažesnėje, grindys iš plytų, lubos iš lentų. Išeinant ị aukščiau aprašytą priemenę - tokios pačios vienvėrės durys ant vyrių ir kabliụ, be spynos. Iš tos priemenès einant ị antrą aukštą ir sustojus to aukšto priemenëje, yra vienas toks pat langas; kairejje pusejje i palëpę virš prieangio durys vienvėrès ant vyrių ir kabliụ, su prancūziška spyna ir rankena; tuo tarpu dešinėje pusėje iš priemenès i gyvenamajị kambarị ieinama per tokias pačias duris ant vyrių, kablių, su prancūziška spyna ir rankena; kambaryje trys tokie patys langai, grindys ir lubos iš lentų; kryžminè duonkepè krosnis iš plytų, prie jos kita, švediška, baltų koklių krosnis be durelių, tik su skardiniu dūmtraukiu, įleistu ị kaminą. Iš šio kambario ị kamarą panašios vienvėrès durys ant vyrių, kablių, su prancūziška spyna, čia du tokie patys langai, židinys iš plytų, virš kurio sumūryti kokliai, prie jo vidutinio dydžio krosnis, padaryta iš geležies skardos, ant keturių taip pat geležiniu kojų bei ilgu dūmtraukiu, ịleistu i židinị. Toliau einant ị mažesnę kamarèlę tokios pačios vienvėrès durys ant vyrių ir kabliụ, be spynos, langas joje

$97-2020$

Acta Academiae Artium Vilnensis 
panašus ị ankstesnius, iš čia i aukščiau aprašytą priemenę - vienvėrès durys ant vyrių, kablių, be spynos (l. 13v), su prancūziška spyna ir rankena. Didesnėje ir mažesnèje kamarose bei priemenėje grindys ir lubos sudètos iš lentų; šio aukšto languose aštuoni išdaužti stiklai. Dabar tuščias.

Kalvè nedidelè, pastatyta nugarinėje to namo pusėje iš senos medienos, uždengta čerpèmis, ị ją senos vienvèrès durys ant vyrių, viduje iš plytų sumūrytas žaizdras ${ }^{41}$ be kamino.

2-as namas, vidurinis, dviaukštis, tokios pat formos ir dydžio, pastatytas iš tašų ant mūrinių pamatų, jo stogas, dengtas gontais, su kaminu, išvestu virš stogo; fasade prieangis su frontonu ant šešių kolonų; grindys ir lubos [prieangyje] iš lentų; einant i priemenę dvivèrès lentelèmis apkaltos durys ant vyrių ir kablių, su prancūziška spyna, raktu ir rankena, su dviem viršuje ir apačioje sklendėmis iš vidaus; [priemenèje] virtuvèlè mūrinè, jos grindys iš plytų, dvivèris langas ant vyrių, kablių, su kampainiais ir dviem skląsčiais bei kilpomis ir kabliukais iš vidaus. Einant tiesiai i gyvenamajji kambarị vienvèrès durys ant vyrių, kablių, su prancūziška spyna ir rankena; trys tokie patys langai mediniuose rėmuose, ittvirtinti glaistu; duonkepė kryžminė krosnis iš plytų, prie jos židinys su kavos spalvos kokliais; i kamarą durys ant vyrių, kablių, be spynos, ten du panašūs langai; židinys su kokliais arba švediška krosnis su durelėmis ir skardiniu dūmtraukiu; i mažą paskutinę kamarèlę vienvėrès durys ant vyrių, kablių, su prancūziška spyna, kitos tokios pačios [durys] iš kamarèlès ị priemenę, ant vyrių, tik su rankena ir kilpomis, be spynos; toks pats langas vienas; visur grindys iš plytų, lubos iš lentų. Iš priemenès einant ị antrą aukštą - sukti staliaus darbo laiptai su turèklu, jais užlipus - priemenè, kurios grindys išklotos lentomis, toks pats vienas langas su vienu išdaužtu stiklu, kairèje pusėje palèpè, išklota lentomis, naudojama kaip sandèlis, be durų. Dešinėje pusėje i gyvenamajji kambarị vienvėrès durys ant vyrių, kablių, su prancūziška spyna ir rankena, trys panašūs langai su vienu išdaužtu stiklu, kryžminė duonkepė krosnis iš plytų, prie jos švediška kavos spalvos koklių krosnis su vienvèrèmis geležinėmis durelèmis ant vyrių ir krosniakaiščiu, ta krosnis apšildo (1. 14) kambari ir kamarą; ì kamarą vienvėrès durys ant vyrių, kablių, su prancūziška spyna ir rankena, langų joje du tokie patys su vienu išdaužtu 
stiklu; tiek kambaryje, tiek kamaroje grindys iš lentų, sienos ir lubos viduje ištinkuotos kalkėmis su gipsu; iš tos kamaros ị mažesnę kamarèlę vienvėrès durys ant vyrių, kablių, su prancūziška spyna, kitos durys iš kamarèlès ị priemenę su tokiais pačiais apkaustais. Vienas sveikas langas; grindys ir lubos iš lentų. Tuščias.

3-ias namas kitos formos, didesnis, taip pat dviaukštis, kur gyvena kalvis Juozapas Makovskis (Makowski), pastatytas iš tašų ant mūrinių pamatų, viršuje su dideliu virš architravo išsikišusiu karnizu su kronšteinais; stogas, dengtas gontais, su vienu iškeltu kaminu. Fasade prieangis illeistas ị vidų, papuoštas dviem kolonomis, grindys plūktos moliu; iš prieangio ị kairę i mažą priemenèlę vienvèrès fasuotos durys ant vyrių, kablių, su prancūziška spyna, rankena ir kabliuku bei kilpomis užkabinimui; dvivèris langas ant vyrių su skląsčiais uždarymui; iš priemenèlès i gyvenamajji kambarị vienvèrès fasuotos durys ant vyrių, kablių, su prancūziška spyna ir rankena, jame trys tokie patys langai, kryžminè duonkepė krosnis, prie jos židinys ir šalia jo sena nedidelẻ kavos spalvos koklių krosnis, apšildanti kambarị ir kamarą. I kamarą vienvèrès fasuotos durys ant vyrių, kablių, su prancūziška spyna ir rankena; du langai, panašūs ị ankstesnius, ir židinys. Kambaryje ir kamaroje grindys iš plytų, lubos staliaus darbo iš lentų. Iš kamaros ị kitą priemenėlę vienvèrès fasuotos durys ant vyrių ir kablių, su prancūziška spyna ir rankena; dešinėje pusèje virtuvèlè, ị kurią vienvėrès durys ant vyrių, kablių, su skląsčiu ir kilpomis užrakinimui kabančia spyna; pati virtuvèlė arba ugniakuras apkaltas lentomis, su mažomis durelèmis ant vyrių, su įleidžiama spyna; vienas toks pats langas; grindys iš plytų; išėjimui i kitą pastato pusę dvivėrès fasuotos durys ant vyrių, kablių, su prancūziška spyna ir rankena bei dviem sklendèmis viršuje ir apačioje. Iš priemenès staliaus darbo laiptai su turèklais ị antrą aukštą, jais užlipus i virš - priemenè, išklota lentomis, su tokiomis pačiomis lubomis; joje du langai, mūrinè virtuvèlè, einant $\underset{i}{i}$ dešinę i gyvenamajji kambarị - vienvėrès durys ant vyrių, kablių, su prancūziška spyna (l. 14v), du langai, kurių penki stiklai išdaužti, vienas židinys; iš to kambario ị didesnị kambarị vienvėrès durys ant vyrių, kablių, su prancūziška spyna, jame trys langai, kurių trys stiklai išdaužti, kryžminė duonkepè krosnis iš plytų, prie jos židinys, o prie židinio

$97-2020$

Acta Academiae Artium Vilnensis 
žalių koklių krosnis, apšildanti du kambarius. Iš kambario ị priemenę vienvèrès durys ant vyrių, kablių, su prancūziška spyna ir rankena; priemenèje toks pats vienas langas su vienu išdaužtu stiklu. Iš priemenès ị galeriją, atitvertą tekinta baliustrada, vienvèrès fasuotos durys ant vyrių, kablių, su prancūziška spyna ir rankena; kitame galerijos gale ị priemenę su laiptais tokios pat vienvèrès fasuotos durys ant vyrių, kablių, su prancūziška spyna ir rankena. Kambariuose, priemenejje ir galerijoje grindys ir lubos sudètos iš lentų. Visų trijų aukščiau aprašytų namų sienos dažytos pelenų spalva, o stogai - raudonai su aliejumi. Tuščias.

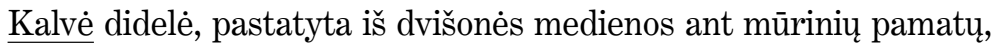
stogas, dengtas čerpèmis, reikalingas remonto, įeinant ị kalvę dvivèrès lentelèmis apkaltos durys ant vyrių, kablių, su didele prancūziška spyna, rutuliu ir dviem antabomis, kitos durys ị kitą kalvès pusę taip pat dvivèrès, apkaltos lentelèmis, ant vyrių, kablių, su antaba ir kilpomis iš vidaus uždarymui basliu; keturi langai, įtvirtinti glaistu, juose trys stiklai sudaužyti. Didelis mūrinis žaizdras su virš stogo išvestu kaminu; už to žaizdro mažas mūrinis rūselis, uždengtas lentomis ir užpiltas žemėmis. Prieangis kalvès fasade ant šešių kolonų, jame grindys ir lubos iš lentų. Prie šios kalvès vienas mažesnis daržas, aptvertas statinių tvora, kitas, didesnis, apsėjamas javais.

Tarp šio namo ir palivarko sodo iš akmenų ir plytų sumūryti platūs kvadratiniai pamatai, ant kurių turi būti statomas palivarkas. $\mathrm{O}$ už jo, prie vidurinio lauko:

$\underline{\text { Klojimas }}^{42}$ didelis, praeitais metais naujai pastatytas iš dvišonès medienos, dengtas šiaudais „po lopeta“; viduje platus kryžminis grendymas, išplūktas moliu, dvylika šalinių ${ }^{43}$ su tarp stulpų užmestomis sienelèmis, ịvažiavimo pusėje dideli dvigubi vartai iš lentų, vietoj bėgūnų turintys keturis geležinius kaiščius, šešis geležinius lankus, viršuje dvi geležinès detalès, ị kurias įeina du kaiščiai, apačioje dvi didelès geležinès [neįskaitomas žodis], i kurias îsistato kiti du kaiščiai, viena prancūziška spyna, ịleista i medì, (l. 15) ir didelè sklendė su dviem kilpomis basliui užspausti, kuris su geležinėmis antabomis yra prie kitos durų pusès; kiti vartai iš klojimo šono taip pat dvivèriai, su tokiais pat apkaustais kaip pirmieji, be spynos, tik su geležiniu strypu prie baslio, ịeinančiu ị vidų, viduje su geležiniu kaiščiu; iš 
kitos klojimo pusės mažos vienvėrès durys ant vyrių, kablių, su geležine sklende ir kilpa viduje. Kitame klojimo gale viduryje pastatyta didelè jauja iš tokio pat medžio, su dviem užstumiamais langeliais; lubos iš lentų, viduje nebaigta, be krosnies ir durų; prie ịejjimo ị ją virš staktos kaminas dūmams išleisti padarytas iš lentų ir išvestas virš stogo. Kluonienoje keturi baragai ${ }^{44}$ javams ir šienui sukrauti su keturiais stulpais ir šiaudiniais stogeliais. Du žaginiai ${ }^{45}$, kiekviename jų - po dešimt karčių.

Kluonelis senas, mažas, dengtas šiaudais, iš apvalių rąstų, skirtas šienui sudèti, ị jị vienvèriai vartai ant bẻgūnų su skląsčiu ir kilpomis užrakinimui pakabinama spyna.

Kepykla $^{46}$, arba valstiečių namas, pastatytas iš apvalių rąstų, su kamarėle greta, be durų, labai senas, jo priemenè taip pat iš apvalių rąstų, gera, o joje nauja kamarèlè - sandèlis iš tokios pačios medienos su mažomis durelèmis ant bėgūnų, ị priemenę mažos durys tik su dviem geležiniais kabliais ir medine sukyne ${ }^{47}$; i kambarị durys ant vyrių ir kablių, su geležine nulenkiama rankena ir skląsčiu su kilpomis; maisto gaminimo krosnis iš plytų; trys langeliai be stiklų; stogas senas, paprastai dengtas šiaudais. Stoginè ant stulpų naujai pastatyta, šiaudais dengta.

Kepykla, antra, prie pat kelio, labai sena, iš tokios pat medienos, jos durys ant vyrių ir kablių; maisto gaminimo krosnis iš plytų, du suolai, keturi langai, iš jų tik vienas su stiklu, ị mažą priemenėlę dvejos senos durelès ant bėgūnų, priemenès gale pastatytas rūsys daržovėms laikyti su lubomis ir užpylimu, durys ant bėgūno su skląsčiu ir kilpomis, krosnis sena iš plytų, trys užstumiami langeliai, stogas dengtas šiaudais, labai senas. Einant toliau:

Valstiečių klojimas mažas, senas, su jauja, kurioje yra mūrinè krosnis, bei durelėmis ant bėgūnų su geležine rankena ir kilpomis, grendymas išplūktas moliu, gale kluonelis be vartų, senas, senas stogas dengtas šiaudais. Du baragai ant keturių stulpų, uždengti šiaudais.

(1. 15v) Kitas klojimėlis, viskuo panašus i pirmajị, senas, be kluonelio.

44 Baragas, taip pat bragas, biragas - ūkinès paskirties pastogè, primytivi daržinè, suręsta iš lengvų konstrukcijų, su kilnojamu stogu, be sienų. Stogas tvirtinamas ant keturių į žemę įkastų vertikalių stulpų.

45 Orig.: przeptot - Lietuvoje naudotas įrenginys šienui ar javams džiovinti, primenantis suremtas dideles kopéčias.

46 Ši kepykla dar minima 1803 m. Verkių dvaro inventoriuje, 1. 259.

47 Orig.: zakrętka - senovinė užsukama durų velkè. 
Trečias klojimèlis, panašus ị pirmaji, su jauja ir kluoneliu.

Tvartas iš apvalių rąstų, dengtas šiaudais, vartai i j ji ant bėgūnų.

Namas prie miestelio tvenkinio, iki gyvos galvos atiduotas kubiliui Ferdinandui Liuboščynskiui (Luboszczyński), pastatytas iš dvišonès medienos ant mūrinių pamatų, fasadu atsuktas i tvenkinį, fasade yra iškištas prieangis, paremtas ant keturių kolonų, su lentinėmis lubomis, be grindų; iš to prieangio ị mūrinị rūsị - vienvėrès durys ant vyriụ, kabliụ, su ịleidžiama prancūziška spyna; jame du maži langeliai be grotų ir stiklo. İeinant i pastatą iš kitos pusès, ị priemenę dvivėrès durys ant vyrių, kablių, su prancūziška spyna ir rankena; joje vienas dvivèris langas ant vyriụ, kabliukų, viduje su dviem skląsčiais, su dvylika vidutinio dydžio stiklų, ittvirtintų glaistu; grindys iš plytų, lubos iš lentų; iš priemenès i gyvenamaji kambarị vienvėrès durys ant vyrių, kablių, su geležine nulenkiama rankena; jame taip pat du langai, kryžminė duonkepė krosnis iš plytų su kaminu, išvestu virš stogo, su geležine skarda kaminui užkišti, šalia kita krosnis iš kavos spalvos koklių, apšildanti kambarị ir kamarą, taip pat su geležine skarda; i kamarą vienvėrės durys ant vyriụ, kablių, su nulenkiama geležine rankena, joje vienas toks pats langas, kitas mažas langelis vèliau išpjautas iš smulkių stikliukų; židinys prie koklinės krosnies su geležine skarda. Kambaryje ir kamaroje tiek lubos, tiek grindys sudètos iš lentų. Tame name šone nuo kiemo pusės sandèliukas, ị kurị vienvėrès durys ant vyrių, kablių, su skląsčiu ir dviem kilpomis. Šio namo stogas dengtas gontais, jis tęsiasi ir virš aukščiau minèto prieangio.

(1. 16) Namas apačioje, pačioje kalno papėdeje, prie kelio, jame veikia smuklè, senas, pastatytas iš dvišonės medienos, reikalingas remonto, aplinkui atramomis sutvirtintas, stogas senas, dengtas gontais, su kaminu, išvestu virš stogo; įeinant ị priemenę dvigubos durys iš lentų ant vyrių su dviem geležiniais klemeriais prie staktos, per kuriuos prasikiša užremiantis duris baslys; grindys ir lubos iš lentų; einant tiesiai iš priemenès - vienvėrès durys ị rūsị ant vyrių, kablių, su dideliu skląsčiu ir dviem kilpomis užrakinimui kabančia spyna; ten lubos ir grindys iš lentų, po grindimis rūsys sutvirtintas medžiu, apgriautas. Kairèje pusėje ị kambarị vienvėrès durys ant vyrių, kablių, su nulenkiama rankena, su skląsčiu iš priemenès pusès, o kabliuku ir keturiomis kilpomis užsikabinimui iš vidaus. Kambaryje du langai 
su smulkiais stiklais mediniuose rèmuose, juose viena dalis atsidaranti, ant vyrių, kabliukų ir skląsčiu; kryžminė krosnis iš plytų duonai kepti ir maistui gaminti, šalia žalių koklių krosnis su variniu indu ${ }^{48}$, apšildanti kambarị ir kamarą; i kamarą vienvèrès durys ant vyrių, kablių, su skląsčiu ir dviem kilpomis; langas toks pat vienas, kambaryje ir kamaroje grindys ir lubos sudètos iš lentų, prie vieno lango viena langinè ant bėgūno.

Einant link Neries ${ }^{49}$ ties perkèla nuo senos apleistos smuklès liko vienas gyvenamasis būstas su prieangiu, labai senas, dengtas skiedromis, taip pat labai senas, skylètas. I kambarị senos vienvèrès durys ant vyrių su medine nulenkiama rankena, o iš vidaus su kabliuku ir dviem kilpelèmis; langai smulkaus stiklo mediniuose rèmuose, seni, du didesni, vienas mažesnis; krosnis iš smulkių žalių koklių, labai sena, ir židinys prie jos taip pat senas, paprastai sumūrytas iš plytų; grindys ir lubos iš lentų. I kamarą durys ant vyrių, tik su dviem kilpomis, be skląsčio. Joje didžioji dalis lubų igriuvusi; du langai be stiklų, prie jų dvejos langinės ant vyrių ir kablių.

Keltas Neries upejje, sudarytas iš dviejų botų, surištas mūrtašiais ir išgrịstas lentomis, aplink ji yra turèklai iš stulpelių, pritvirtintų septyniomis didelèmis geležinėmis atabomis, viename gale yra du irklai, ant kurių yra keturi mažesni apkaustų lankai ir dvi mažos ašys (l. 16v), viršuje dvi didelès antabos, apačioje dvi poros didelių vyrių, viduryje stulpas, pritvirtintas keturiomis antabomis, su tekintu mediniu ratu, turinčiu dideli geležinị veleną, viršuje metalinis lankas kartu su antaba, apačioje viena didelè antaba, keturi klemeriai, viena kabè, botų gale du ratukai su kilpomis, dvi grandinès su keturiomis kilpomis; keturi klemeriai, pro kuriuos prasikiša basliai. Keltuvas ant dviejų stulpų su lentiniu stogu, ant kurio pritvirtinta pinta virvè, toliau du surišti stulpai, ant kurių remiasi ta virvė; kitoje Neries pusejje tik vienas stulpas su atramomis, prie kurio pririštas kitas virvès galas; vienoje ir kitoje Neries pusėje yra dvi lentomis išklotos užvažiavimo rampos. Praeitais metais padaryta nauja šimto dvidešimties sieksnių ${ }^{50}$ virvè. Du seni $[\ldots]^{51}$.

Einant pylimu, supiltu tarp kanalo ir senojo sodo, $\underset{z}{i}$ bravoro pastatus, ị kiemą vienvėriai vartai ant bėgūnų su medine sklende, pro kuriuos ìjjus kairèje pusèje:

48 Orig.: banka.

49 Orig.: Wilia.

50 Sieksnis $-1,83 \mathrm{~m}$.

51 Neįskaitomas žodis. 
$\underline{\text { Klètis }}^{52}$ iš dvišonès medienos, sena, dengta gontais, fasade turinti prieangị iš stulpelių, o iš jo ị sandèlị vienvėrės durys ant vyrių, kablių, su illeidžiama spyna ir raktu; viduje trys aruodai grūdams supilti. Einant toliau toje pačioje pusejje:

Arklidė nedidelè prie tvoros, pastatyta iš apvalių rąstų, šešiems arkliams; šalia stoginè ant stulpų po vienu čerpèmis dengtu stogu, kurị reikia remontuoti; i arklidę vienvèrès durys ant geležinių vyrių, kablių, su rankena ir kilpomis; viduje gardai, èdžios ir grindys iš sijų.

Dviaukštė klėtis $^{53}$ prieš stoginę iš lentų, aplinkui prieangis su laiptais, stogas senas, dengtas gontais; i antrą aukštą vienvèrès durys ant vyrių, kabliu, su skląsčiu ir kilpomis užrakinimui pakabinama spyna; apatinių patalpų lubos sudaro antro aukšto grindis.

Tame pačiame kieme kairẻje po lentụ stogeliu šalia dvi iš plytų sumūrytos krosnys kepti duonai statybų darbininkams.

Ant Neries kranto:

Prūsiško mūro bravoras ir aline $\dot{e}^{54}$, vienas galas, kur vėsintuvas, [pastatytas] aplink iš apvaliụ rąstų, ị ji dvivèrès durys iš kiemo ant vyrių, kablių, prie vienos varčios viršuje (1. 17) kabliukas su dviem kilpomis, prie kitos varčios skląstis su dviem geležinėmis kilpomis užrakinimui pakabinama spyna iš vidaus. Ugniakuras ${ }^{55}$ su virš stogo išvestu kaminu, kuriame yra katilas, jam skirta anga apačioje su geležine plokšte apačioje ir su geležies skarda angai uždaryti, ant vyrių, su nulenkiama rankena, virš angos - apvalus langelis su skardinėmis durelèmis ant vieno vyrio ir su nulenkiama rankena. Kamino viduryje, virš katilo, anga, per kurią išeina ugnis, su geležinèmis durelëmis ant vyrių, su nulenkiama rankena. Nuo to katilo ugniakuro ị kiemą vienvėrès durys dèl šviesos, ant vyrių, kablių, su kabliuku per vidurị ir kilpomis užkabinimui. Aplinkui katilą mediniai rẻmai apkalti geležinėmis vinimis. Pačiame bravore dešinėje pusèje didelis alaus vėsintuvas, reikalingas remontuoti; jame trys langai be stiklo su langinėmis ant vyrių, kablių, su kabliukais ir kilpelèmis užkabinimui iš vidaus; grindys išgrịstos akmenimis; išèjimui ị kitą bravoro pusę, prie Neries, vienvèrès durys ant vyrių, kablių, su nulenkiama rankena, prie tų durų durys į mažą raštininko

52 Pastatas grūdams, orig.: szpichlerz.

53 Orig.: lamus.

54 Gali būti, kad šis pastatas jau minimas 1776 m. inventoriuje; 1776 m. Verkių palivarko inventorius, 1.1.

55 Orig.: horno. 
kambarèlį, vienvèrès, ant vyrių, kablių, su nulenkiama rankena; krosnis jame mūryta iš plytų, su skarda angai uždengti ant vyriukų, kablių, su nulenkiama rankena; langas vienas mediniuose rèmuose, smulkaus stiklo, dvivèris, ant vyrių, kablių, su dviem skląsčiais iš vidaus; grindys iš plytų, lubos sudètos iš lentų; tas kambarys viduje moliu ištinkuotas. Išèjus iš šio kambario iš karto dešinejje pusėje ị alinę durys vienvèrès ant vyrių, kablių, su skląsčiu ir dviem kilpomis kabančiai spynai, virš jų viršuje langelis be stiklo, su medine langine ant vyrių, su kabliuku užkabinimui; viduje vienas stiklo langas mediniuose rèmuose, iš plytų, lubos sudètos iš lentų; iš alinės ị kiemą dvivèrès durys ant vyrių, kablių, su geležine velke užsklendimui iš vidaus ir skląsčiu bei dviem kilpomis iš vidaus užrakinimui pakabinama spyna, prie vienos durų pusès dvi geležinès sklendès viršuje ir apačioje. (l. 17v) Šio bravoro gale, nuo alinès pusès, pristatyta kepykla samdiniams su priemene, iš apvalių rąstų, ị priemenę durų nėra, iš priemenès gi ị kambarị vienvėès durys ant vyrių, kablių, su nulenkiama rankena; kambaryje du smulkaus stiklo langai mediniuose rėmuose, krosnis maistui gaminti ir duonai kepti, iš plytų, su kaminu, išvestu virš lubų; grindys iš žemės, lubos iš lentų, minètoje priemenėje maža kamarèlè, ị kurią vienvèrès durys ant vyrių, kablių, su skląsčiu ir kilpomis užrakinimui pakabinama spyna, joje vienas langelis be stiklo, lubos iš lentų; stogas virš bravoro dengtas pusapvalèmis lentomis, kambarèlis gi ir kepykla dengta skiedromis.

Šulinys prie bravoro netoli Neries suręstas iš dvišonès medienos, jame vamzdis su geležiniu lanku viršuje, tai yra pompa; šulinyje du geležimi apkaustyti kibirèliai su storu ilgu geležiniu virbu ir medine, taip pat geležimi apkaustyta rankena, dviem ašimis ir dviem lankeliais.

Dešinėje kiemo pusėje, prie senojo apatinio sodo:

Salyklinė, pastatyta iš dvišonès medienos, stogas apačioje dengtas pusapvalèmis lentomis, viršuje gontais; įeinant ị ją vienvèrès durys ant vyrių, kablių, su prancūziška spyna ir raktu; grindys iš plytų, lubos iš lentų, plytinè krosnis su kaminu, išvestu virš stogo, langų mediniuose rėmuose joje trys, visi aklinai užkalti; iš salyklinès ị džiovyklą vienvėrès durys ant vyrių, kablių, su geležine sklende, joje krosnis žemèje sumūryta iš plytų, su mediniais laipteliais salyklui džiovinti; langai joje tokie patys du, grindys iš

$97-2020$

Acta Academiae Artium Vilnensis 
plytų, lubos sudètos iš lentų; iš šios džiovyklos einant ị kiemą durys dvivėrès, ant vyrių, kablių, su skląsčiu ir kilpomis pakabinamai spynai.

\section{Verkių lentpjūvès pastatų aprašymas}

$\underline{\text { Lentpjūvè }}^{56}$ už didžiojo sodo nauja, prie Neries upės ant alksninių polių, su prieangiu aplinkui pastatą, papuoštu keturiasdešimt dviem kolonomis, jame grindys ir lubos sudètos iš lentų, lentpjūvès viduje grindys taip pat iš lentų; lentpjūvès sienos aplinkui apkaltos lentomis ir kartu su kolonomis nudažytos pelenų spalva, jos stogas dengtas gontais, dažytas raudonai, pačiame stogo viduryje pastatyta salytè, iškylanti virš stogo pustrečios uolekties, dèl ị viršu pasikeliančių rèmų; ta salytè taip pat aplinkui apkalta lentomis ir nudažyta pelenų spalva, su stogeliu (1. 18) tokiu kaip ir lentpjūvės, nudažytu raudonai. Visame pastate yra penkios dvivèrès staliaus darbo durys, apkaltos lentelèmis, su geležiniais vyriais ir kabliais, o iš vidaus su aštuoniomis grubiomis antabomis užkišimui mediniais strypais; iš jų vienos durys su ịleidžiama prancūziška spyna ir raktu; šeštos durys i Neries upės pusę vienvėrès, taip pat staliaus darbo, apkaltos lentelėmis, ant geležinių vyrių, kablių, su kabliuku ir kilpomis užkabinimui iš vidaus; kampe, netoli tų durų, dešinėje pusèje pastatyta kamarèlè iš lentų ịvairiems lentpjūvès ịrankiams pasidèti, jos durys vienvèrès staliaus darbo ant geležinių vyrių ir kablių su medine sklende ir raktu; šeši dvivèriai balto stiklo langai, kiekviename lange yra po dvidešimt keturias mažas dalis ant vyrių su kabliukais iš vidaus. Lentpjūvès viduryje yra iš pušies medžio padaryti trys vežimai, ant kurių guli rąstai, kai pjaunami; tų vežimų galai suspausti penkiolika geležinių varžtų ir trimis geležiniais lankais. Trys dideli ąžuoliniai rẻmai, kuriuose įtvirtinti pjūklai, staliaus darbo, apkaustyti dvylika stambių geležinių lankų; šių rėmų šonuose viršuje ir apačioje prikalta dvylika uolekties ilgio skardų; vežimams traukti yra trys dideli apvalūs geležiniai ratai su dantukais, ittvirtinti ant stambių geležinių daugiau nei pustrečios uolekties ilgio strypų; kituose tų strypų galuose yra trys iki pusės uolekties ilgio žalvariniai krumpliaračiai (šeštarnès), kurie vežimus traukia; tuo tarpu viršuje virš rėmų medinis volas, apkaustytas keturiais geležiniais lankais, to volo viduryje didelis geležinis ratas su dviem geležiniais kabliais, prie to volo pririštas apie dešimties sieksnių ilgio lynas, 
kuriuo traukiami rąstai iš kanalo ị lentpjūvę. Treji laiptai iki vandens rato, dveji iš šonų, o treti iš lentpjūvès vidurio, virš jų grindyse gulinčios vienvėrès durys ant bėgūno, pritvirtintos geležiniais klemeriais; vandens ratas didelis medinis, jame naujas geležinis volas su išlenkimu trims rėmams, tuose išlenkimuose yra trys ilgi ąžuoliniai, stambiais geležiniais lankais apkalti grąžulai, kurių kitas galas siekia rėmus; kitame grąžulų gale trys ąžuoliniai voleliai (l. 18v), įtvirtinti rèmų galuose, apkaustyti geležiniais lankais; aukščiau paminètas volas guli ant dešimties stovinčių stulpelių, apkaustytų dešimčia geležinių lankų. Nuo kanalo pusės prie lentpjūvės didelė skrynia iš storų lentų, jos šonai ir dugnas užkaišyti ir aplieti smala, per šią skrynią vanduo krenta ant rato, joje yra užtvara su dviem keltuvais, prie kurių yra trys geležiniai varžtai ir kiti geležiniai apkaustai; nuo vandens rato eina lentinis vamzdis, kuriuo vanduo išteka į Nerị. Nuo kanalo pusès prieš duris - dvi kolonos, apkaustytos keturiais geležiniais lankais, sukasi ant keturių geležinių kaiščių.

Mūrinio namo, skirto lentpjūvininkui, aprašymas

$\underline{\text { Namas }}^{57}$ trijų aukštų, mūrinis, pastatytas truputị toliau prie to paties kanalo, stogas dengtas gontais, dažytas raudonai, su kaminu, išvestu virš stogo; įeinant ị namą apačioje durys ị priemenę staliaus darbo, dvigubos, ant vyrių, kablių, su ịleidžiama prancūziška spyna ir raktu; priemenėje vienas didelis balto stiklo langas ant vyrių ir kabliukų; einant iš priemenės kairèje pusėje kambarèlis be krosnies su dvigubomis staliaus darbo durimis ant vyrių ir kablių, su įleidžiama prancūziška spyna ir raktu; kambarèlyje vienas balto stiklo langas ant vyriukų ir kabliukų; iš to kambarèlio - kitas didelis kambarys, ị jị vienvèrès staliaus darbo durys ant vyrių ir kablių su illeidžiama prancūziška spyna ir raktu; jame trys tokie patys langai. Išèjus iš tų kambarių $i$ anksčiau minètą priemenę kairėje pusèje virtuvèlè, ị kurią vienvėrès staliaus darbo durys ant vyrių ir kablių su įleidžiama prancūziška spyna ir raktu; joje vienas balto stiklo langas ant vyriukų ir kabliukų; iš tos priemenès nauji sukti lentiniai laiptai ì antrą aukštą, nauji, dar be turèklų, besilaikantys ant įmūrytų kablių. Durys ị pirmą kambarị iš lentų, skydinès, dvivèrès, staliaus darbo, ant vyrių ir kablių, su įleidžiama spyna, raktu ir šlosaku, dviem rutuliukais atidarymui; vienas didelis langas kaip ir apačioje 
dvivèris, skaidraus stiklo mediniuose staliaus darbo rèmuose ir sutvirtinti glaistu, su vyriukais ir kabliukais, su dviem sklendèmis ir kampainiais. (1. 19) Krosnis, apšildanti du kambarius, švediška, baltų koklių, su ị kaminą įmūrytu geležiniu vamzdžiu, jos durelès dvigubos, ant vyriukų ir kabliukų, su nulenkiama rankena ir dviem orlaidèmis ant vyriukų su dviem sklendèmis; prieš krosni grindys Vingio fabriko, viena eile [sudètos], sugadintos. Durys ị kitą kambarị ir langai tokio pat darbo, su tokiais pat apkaustais ir stiklu kaip ir pirmame kambaryje. Židinys sienoje, prie jo viena eilè minèto fabriko grindų. Abiejuose tuose kambariuose lubos ir grindys iš lentų. Grịžus atgal iki laiptų kairèje pusėje i mūrinę virtuvėlę vienvėrès lentų skydų staliaus darbo durys ant prancūziškų vyrių su įleidžiama spyna, rankena, šlosaku ir raktu; tokios pačios durys ị sandèliuką; langas virtuvėje ir sandẻliuke tokie kaip aukščiau aprašytuose kambariuose, lubos ir grindys iš plytų. Iš ten nebaigtais laiptais ị trečią aukštą. Nedidelè priemenè su dviem tokio pat stiklo ir apkaustų langais; iš priemenès kairèje kambarèlis, ị kurị dvivèrès staliaus darbo durys ant vyrių ir kablių su įleidžiama prancūziška spyna ir raktu, jame du tokie patys langai, iš šio kambario ị kitą, didesnị, staliaus darbo durys ant vyrių su įleidžiama prancūziška spyna ir raktu, tame kambaryje keturi langai, kurių apkaustai ir stiklai panašūs i ankstesnius; abiejuose kambariuose krosnių dar nèra, grindys iš plytų, išeinant iš jų i priemenę kairèje pusėje virtuvèlè, ị kurią vienvėrès staliaus darbo durys ant vyrių ir kablių su įleidžiama prancūziška spyna ir raktu, joje vienas balto stiklo langas ant vyriukų ir kabliukų užkabinimui iš vidaus.

\section{Ivairių statiniu netoli lentpjūvès aprašymas}

Kalkinè, arba pašiūrè, šalia to mūrinio namo, sena, ant stulpų, su apgriuvusiu skiedrų stogu, joje greta dvi apvalios mūrinės krosnys kalkakmenims degti; po tuo stogu yra dvi krosnys išdegtų kalkių. Tarp kalkinès ir aukščiau minèto namo penkios lentomis išklotos duobės, pilnos pripiltos kalkių ir užpiltos žeme. Dabar galutinai griūvanti.

Namas iš apvalių iš dviejų šonų aptašytų rąstų, pastatytas kiek toliau nuo kalkinès, prie pat Neries, netoli salos ${ }^{58}$; lentinès durys ị priemenę ant ilgu vyrių su kabliais, su nulenkiama rankena (l. 19v) (prie kurios yra 
virvelè), šlosaku; durys ị kambarị tokios pačios kaip i priemenę, kambaryje trys skaidraus stiklo langai mediniuose rèmuose, du iš tų langụ turi po vieną atsidarančią dalį; ūkinè mūrinė krosnis su pakrosniu ir virš stogo išvestu kaminu, o kamine geležinė skarda ištraukiama su rankenėle; durys ị kamarą lentinės, ant ilgu vyrių ir kablių, nulenkiama rankena, prie kurios yra dirželis ir šlosakas, bei su skląsčiu ir kilpomis užrakinimui pakabinama spyna; vienas skaidraus stiklo langas mediniuose rèmuose, kambaryje, kamaroje ir priemenejje lubos iš lentų, grindys sudètos iš plytų; lentinès durys ì sandèliuką ant ilgų vyrių ir kablių, su skląsčiu ir dviem kilpomis užrakinimui pakabinama spyna. Šis pastatas dengtas šiaudais „po lopeta“, aplietas kalkėmis apsaugoti nuo vejųu. Abiejuose šio pastato galuose sodinami daržai aptverti pusapvalèmis lentomis.

Staliaus Budrevičiaus (Budriewicz) namas pastatytas kiek toliau prie Neries, priešais salą, iš rąstų, aptašytų iš dviejų šonų, nebaigtas, dengtas pusapvalèmis lentomis, fasadu atsuktas ị Nerị, viena siena iš mediniu stulpų; iš šono iejejimas i priemenę be durų, didelis kambarys taip pat be durų ir langų bei be krosnies, taip pat ir kamara; i kitą kamarą vienvėrès durys ant vyrių, kablių, su skląsčiu ir kilpomis, vienas langas su stiklu ir langine ant vyrių, kablių, su geležiniu uždarymo strypu, ịleistu ị vidų; maža krosnis sumūryta iš plytų, grindys ir lubos iš lentų.

Pastaba. Tą namą pasistatè pats amatininkas Budrevičius, jam skirta iždo medžiagų: sienojų dvi kapos ${ }^{59}$, colinių lentų trys su puse kapos, taip pat pusapvalių lentų, plytų ir stiklo duota iš iždo.

\section{(1.20) Verkiu smukliu aprašymas}

Austerija $^{60}$ Jeruzalès miestelyje, didelè, dviaukštè, mūrinè, su karnizu viršuje, virš jos laužytas stogas dengtas čerpèmis, su virš stogo išvestu kaminu; prie jos klojimas taip pat dviaukštis, pusapskritis; i ji įeinant nuo tvenkinio pusės dvivėriai lentelèmis apkalti vartai ant šešių porų vyrių, vienoje pusėje ąžuolinis baslys, pritvirtintas geležiniu varžtu, o kitoje pusėje illeidžiama prancūziška spyna bei didelis klemeris su dviem kilpomis tam basliui užrakinti. İ kitą klojimo pusę išeinant - dvivèriai lentelèmis apkalti vartai su spyna, klemeriu ir kitais panašiais ị pirmų vartų apkaustais; klojime

59 Kapa - 60 vienetu.

60 Dabar Jeruzalès g. 45, Kultūros vertybių registro kodas 25014 (Verkių dvaro sodybos administracinis pastatas). 
kairejje pusėje tarp mūrinių kolonų arklidè septyniolikai arklių su grindimis ir ėdžiomis iš sijų, lubos laikinos, sudètos iš lentų, nebaigtos. Dešinėje pusèje nuo pirmųjų vartų kita arklidė tarp mūrinių kolonų, skirta aštuoniolikai arklių, be grindų ir lubų, tik su èdžiomis, iš jos išeiti ị vieškelị mažesnès dvivèrès lentelėmis apkaltos durys su spyna ir tokiais kaip ir pirmujų apkaustais, virš ju pailgas langelis be stiklo su dviem ịmūrytais geležiniais kabliais; toliau einant toje pačioje pusèje dvivèrès lentelèmis apkaltos durys ant vyrių, kablių, su prancūziška spyna ir rankena, ị koridorių, vedantị i vieškelį, virš jų langas taip pat be stiklo; dar toliau einant toje pačioje pusėje virtuvè su mūriniu gaubtu ant stulpo, prie jos vieta, iš kur kūrenamos koklinės krosnys, čia grindys iš plytų; du dideli dvivèriai langai su dešimčia didelių žalio stiklo lakštų mediniuose staliaus darbo rèmuose, sutvirtinti glaistu, ant vyrių, kablių, apačioje ir viršuje su dviem didelèmis geležinėmis sklendèmis; grindyse ì rūsius siauras skliautuotas koridorius, ị kurị veda mediniai laiptai, jais nusileidus apačioje priemenè, o iš jos ị pirmą rūsị dvivèrès lentelèmis apkaltos durys ant vyrių, kablių, su prancūziška spyna bei dviem geležinėmis sklendèmis viršuje ir apačioje, šalia du maži langeliai be grotų ir stiklo; kairejje pusèje ị antrą rūsį vienvėrès neapkaltos lentelèmis durys ant vyrių ir kablių, be spynos, du tokie patys langeliai; iš aukščiau aprašytos virtuvès i kamara šalia gyvenamojo kambario dvivèrès (1. 20v) lentelèmis apkaltos durys ant vyrių, kablių, su prancūziška spyna ir rankena bei dviem sklendèmis viršuje ir apačioje; kamaroje langas, panašus i aprašytus virtuvėje, krosnis kavos spalvos kokliu ant aukšto mūrinio pamato, kūrenama per židini iš vidurinio kambario, ị kurị dvivèrès lentelèmis apkaltos durys su tokia pačia spyna ir apkaustais; jame du tokie patys kaip ir ankstesni langai, kavos spalvos koklių krosnis, apšildanti šį ir kitą, didesnị, smuklès kambarị; iš šio kambario i minètą smuklès kambarị dvivèrès fasuotos durys, o iš čia i aukščiau aprašytą klojimą kitos durys taip patfasuotos, ant vyrių, kablių, su prancūziška spyna ir kitais apkaustais kaip viduriniame kambaryje ir kamaroje. Langai tokie patys du, židinys netoli krosnies; tuose dviejuose kambariuose ir kamaroje grindys molinès, juodai degtos didelėmis kvadratinėmis plytomis, o lubos sudètos iš lentų. Antras aukštas nebaigtas, kalbant apie duris, langus, krosnis ir grindis, gi lubos kalkèmis pradètos tinkuoti, nebaigtos ${ }^{61}$.

611803 m. inventoriuje ši austerija aprašyta kaip mūrinè, dviaukštè, kvadratinio plano, su pusapskričiu klojimu, dengta čerpèmis, apačioje buvo 3 gyvenamieji kambariai su rūsiu, antras aukštas vis dar buvo nebaigtas; $1803 \mathrm{~m}$. Verkių dvaro inventorius, 1. 259v. 
Namas kitoje kelio pusėje Notkės Volfovičiaus, buvusio nuomininko, lëšomis pastatytas iš apvalių rąstų, senas, jo stogas dengtas skiedromis, tik virš gyvenamojo kambario ir priemenès taip pat senas, griūvantis; priemenè atskirai iš kẻnio rąstų pristatyta, ị ją mažos vienvėrès durys ant vyrių, kablių, su didele geležine sklende iš vidaus, su skląsčiu ir kilpomis; i kambarị durys taip pat vienvèrès ant vyrių, kablių, su skląsčiu ir kilpomis; jame trys smulkaus stiklo langai mediniuose rèmuose, viename yra viena atsidaranti dalis ant vyrių, kabliukų, su skląsčiu iš vidaus. Kryžminė duonkepè krosnis su kaminu, išvestu virš lubų, šalia gera kavos spalvos koklių krosnis; i kamarą senos vienvėrès fasuotos durys ant vyrių, kablių, su antaba bei illeidžiama spyna; langelis mažas, smulkaus stiklo; kambaryje grindys iš plytų, kamaroje - iš molio, lubos tiek kambaryje, tiek ir kamaroje sudètos iš lentų. Prie priemenès daržovių sandèlis, šalia sandèlis iš tokio pat medžio pristatytas, šiaudais dengtas, ị daržovių sandèlị vienvėrès durys ant vyrių, kablių, su skląsčiu ir kilpomis; krosnelè iš akmenų; du langeliai be stiklų, lubos iš lentų, grindys iš žemès, ị sandèlị (1. 21) durų nėra, tik vienas geležinis kablys iš vidaus.

Bravorëlis nedidelis prie tvenkinio pastatytas iš apvaliu rąstų, dengtas šiaudais, i ji durys iš lentų ant bėgūno, vienvėrès, su skląsčiu ir kilpomis užrakinimui pakabinama spyna; jame iš plytų mūryta krosnis ${ }^{62}$ vienam katilui; kieme iškastas medžiu sutvirtintas šulinys, prie jo svirtis ant vieno stulpo vandeniui kelti; ten pat pirtelè su akmenine krosnimi su durelėmis ant bėgūnų. Šalia to bravorèlio:

Kluonelis pastatytas iš apvalių rąstų, dengtas šiaudais, vartai i jij iš lentų ant bėgūnų, su skląsčiu ir geležinėmis kilpomis užrakinimui pakabinama spyna. Grendymas išplūktas moliu, abiejose pusėse keturios šalinės atskirtos rąstais tarp stulpų. Pastaba. Už šị kluonelị ir bravorèlį iždas Notkei sumokèjo, žiūrèti sąskaitą su juo.

Ivažiavimo smuklè Fabijoniškių kaime ${ }^{63}$ prie vieškelio, einančio iš Vilniaus ị Širvintas, iš rąstų, aptašytų iš dviejų šonų, neseniai pastatyta ant mūrinių pamatų, dengta šiaudais „po lopeta“ su virš stogo išvestu kaminu, su kopéčiomis nuo žemės net iki viršaus, skirtomis kaminams valyti. Šios smuklès galuose yra du akmenimis išgrịsti klojimai su ėdžiomis prie sienos 
ir kolonomis, ị kiekvieną iš jų didelès staliaus darbo durys ant didelių vyrių ir kablių, vienoje pusejje visur basliai, prikalti dviem klemeriais, kitoje durų pusejje prie staktos dideli klemeriai su dviem kilpomis tiems basliams užrakinti pakabinama spyna. Nuo vieškelio pusès smuklès centre prieangis, papuoštas šešiomis kolonomis, truputi iškištas i priekị, su grindimis ir lubomis iš lentų, iš jo einant i priemenę dvivèrès staliaus darbo lentelėmis apkaltos durys ant vyrių, kablių, su velke viduje ir viena geležine sklende viršuje; priemenëje mūrinè virtuvė, grindys iš plytų, lubos sudètos iš lentų, dešinėje pusėje, einant i gyvenamaji smuklès kambarį, staliaus darbo vienvėrės durys ant vyrių, kabliu, su nulenkiama rankena; tame kambaryje du dvivèriai langai mediniuose rėmuose ant vyrių, kabliukų, su skląsčiais viduje, trečias mažas langelis ị klojimą, užstumiamas lenta; sena pilkų koklių krosnis ant plytinio pamato (1. 21v), apšildanti kambarị ir kamarą, prie jos iš plytų mūrytas židinys, du suolai prie sienų; kitos tokios pačios durys ì klojimą, ant vyrių, kablių, su nulenkiama rankena ir geležiniu rutuliu prie staktos; iš kambario ị kamarą trečios durys taip pat vienvèrès ant vyrių, kablių, su nulenkiama rankena; joje iš plytų mūryta krosnis valgiui gaminti ir duonai kepti; langas tokio pat stiklo mediniuose rèmuose su viena atsidarančia dalimi ant vyriụ, kablių, su skląsčiu iš vidaus, kitas langas užmūrytas; kambaryje ir kamaroje grindys iš plytų, lubos sudètos iš lentų; iš tos kamaros ị kitą kamarą vienvèrès durys ant vyrių, kablių, su skląsčiu ir dviem kilpomis užrakinimui pakabinama spyna; vienas langas mediniuose rẻmuose, neatsidarantis; lubos iš lentų, grindys iš žemès supiltos, jose mūrinis rūsys su gulinčiomis durimis be apkaustų, viduje nebaigtas. İ kairę pusę iš aukščiau minètos priemenès i̇ svečiu kambarị vienvėrès durys ant vyrių, kablių, su prancūziška spyna ir raktu; jame du dvivèriai langai, panašūs i aprašytus aukščiau; trečias langas ị klojimą užtraukiamas lenta, be stiklo; kavos spalvos koklių krosnis, apšildanti kambarị ir kamarą, prie jos židinys; durys ị kitą klojimą vienvėrès ant vyrių, kablių, su prancūziška spyna ir raktu; i kamarą trečios durys taip pat vienvèrès ant vyrių, kablių, su nulenkiama rankena ir antaba bei skląsčiu ir dviem kilpomis užrakinimui pakabinama spyna; du tokie patys dvivèriai langai be apkaustų; kambaryje grindys iš plytų, kamaroje iš plūkto molio, lubos tiek kamaroje, tiek ir 
kambaryje sudètos iš lentų. Fasade, t. y. nuo vieškelio pusės, ketverios dvigubos langinės ant vyrių ir kablių, o iš nugarinės smuklès pusės prie langų yra nuosavos nuomininko Ropienio (Ropień) langinès.

Šlinys kitoje vieškelio pusèje apie dešimties sieksnių gylio, sutvirtintas medžiu, virš jo stogelis ant keturių stulpų, uždengtas gontais, šonai aplink stulpus lentomis apkalti, prie šulinio du ąžuoliniai kibirai, kiekvienas apkaustytas trimis geležiniais žiedais, su dviem net dugną siekiančiomis auselëmis, rankenomis ir daugiau nei uolekties ilgio geležinėmis grandinèlèmis, pritvirtintomis prie lynų; viršuje vandeniui kelti yra kabas, arba medinis ratas, besisukantis ant geležinės ašies, apkaustytas geležimi, prie jo didelis rẻmas su dviem sparnais, tarp kurių yra ị balkị ileistas velenas.

(1. 22) Bravorèlis nedidelis, pastatytas iš îvairios senos medienos, jo stogas iš pusapvalių lentų, o virš jų paprastai šiaudais dengtas, i j ji vartai dideli, vienvėriai, iš lentų, ant bėgūnų, su skląsčiu ir dviem kilpomis užrakinimui pakabinama spyna; jame mūrinè krosnis vienam katilui; dešinėje pusẻje pirtelè iš rąstelių atskirai nuomininko Ropienio pasistatyta, jos durelès ant vyrių ir kablių, krosnis iš akmenų, lubos iš lentų. Tarp šio ir didžiojo bravoro pastatyta rąstų siena, o iš kitos pusės stulpai, ant kurių didelè stoginė, paprastai uždengta šiaudais. Einant akmeniniu grindiniu toliau:

Didelis bravoras, dabar paverstas kluonu, iš dvišonės medienos, ant mūriniu pamatų, stogas dengtas šiaudais „po lopeta“; i jị įeinant dvivèrès durys iš lentų ant vyrių, kablių, su didele geležine velke ir rankena iš kiemo pusės užrakinimui pakabinama spyna, viduje gi skląstis su dviem kilpomis taip pat pakabinamai spynai; grendymas plūktas moliu, nuo jo kairëje i jaują vienvėrès durys ant vyrių, kablių, su skląsčiu ir dviem kilpomis taip pat pakabinamai spynai; krosnis iš plytų, lubos iš lentų, vienas didelis langas be stiklo, užmūrytas, su langine ant vyrių ir kablių; du maži langeliai taip pat be stiklų; dešinėje pusèje nuo įejjimo, kur kraunami javai, didelis langas be stiklo su langine ant geležinių vyrių ir kablių.

Smuklè, vadinama Riešs ${ }^{64}$, prie vieškelio iš Vilniaus i Molètus (i ją važiuojant per Riešès upę yra tiltas su turèklais, išklotas lentomis, per kuri pervažiavus yra žemiau aprašytas šliuzas ${ }^{65}$ ), naujai pastatyta iš rąstų, aptašytų iš dviejų pusių, su prieangiu ant dviejų tokio pat medžio kolonų; 
vienas protarpis, skirtas klojimui, iš šulų pristatytas, nebaigtas; jis ir visa smuklè ant mūrinių pamatų, ši pastato dalis dengta šiaudais „po lopeta“; ieinant ị klojimą dideli vienvėriai vartai ant bėgūnų, sugadinti; klojime kairèje pastatytos šešios kolonos arkliams pririšti, taip pat ant mūrinio pamato. I gyvenamajji smuklès kambarị durys vienvèrès ant vyrių, kablių, su nulenkiama rankena ir kabliuku (l. 22v) bei dviem kilpomis iš vidaus. Jame keturi langai mediniuose rèmuose, iš jų du turi po vieną atsidarančią dalį; trečias langelis mažas, be stiklo, su medine užstūma; kavos spalvos koklių krosnis, apšildanti kambarị ir kamarą, prie jos iš plytų sumūrytas netinkuotas židinys; grindys iš plytų, lubos sudètos iš lentų. Iš kambario į kamarą durys taip pat vienvèrès, staliaus darbo, ant vyrių, kablių, su prancūziška spyna ir raktu; vienas langas tokio pat stiklo, mediniuose rėmuose; kryžminè duonkepè krosnis nebaigta, jos kaminas išvestas virš lubų, netinkuotas; grindys iš molio, o lubos iš lentų; kitame gale, nuo senosios smuklès pusès, iš vienos ir kitos pusės yra du tarpsniai sienų, kuriose įvažiavimo vartai dideli vienvèriai ant bėgūnų; tame pačiame gale prie vartų maža kamarèlè - sandėliukas su durimis ant vyrių, kablių, su skląsčiu ir dviem kilpomis užrakinimui pakabinama spyna; šalia kitos durys ị kambarị, kažkada gyvenamajị, o dabar tuščią, vienvėrès, ant vyrių ir kablių, jame vienas langas, kurio stiklų dauguma išdaužyta, plytinè krosnis sugriauta. Iš to kambario ị mažesnị ir dar labiau apgriautą kambarị durys ant bėgūnų; šiuose kambariuose lubos iš lentų. Stogas virš kamaros, kambario ir dalies klojimo labai senas, iš skiedrų (dranyčių), mažesnis kambarèlis dengtas čerpėmis.

Ūkinis klojimas pastatytas iš apvalių rąstų, paprastai šiaudais dengtas, viduje vienoje ir kitoje pusejje yra šeši tarpai ${ }^{66}$, grendymas iš molio suplūktas, vartai i ji iš lentų ant bėgūno, vienvèriai, su skląsčiu ir dviem kilpomis užrakinimui pakabinama spyna. Kitoje kelio pusėje:

Nedidelis, senas tvartelis, pastatytas iš tokių pačių rąstų, stogas šiaudais dengtas, skylètas, vartai iš lentų ant bėgūnų. Truputị toliau link upès:

Bravorèlis labai senas, griūvantis, jo stogas dar blogesnis, dengtas šiaudais, vartai seni, krosnis ${ }^{67}$ vienam katilui, mūryta iš plytų; šalia negilus šaltinis vietoj šulinio; iš šio bravorèlio ị pirtelę visiškai sulūžusios durelès ant bėgūnų, joje krosnis akmeninė, lubos iš lentų, du maži langai be stiklų; 
virš lubų yra džiovykla, taip pat apgriuvusi; ši pirtelè po vienu stogu. Smuklès užnugaryje dalis skiedromis dengtos pašiūrès, sena, virš plytų degimo krosnies, sumūrytos iš plytų, didele dalimi sugriautos, statant smuklès mūrinius pamatus.

(1. 23) Parko ir jame esančių statinių, altanų bei kt. aprašymas

Parkas, arba laukinis sodas, išsidėstęs galais tarp Jeruzalès miestelio ir Verkių pilies kalno, vienu šonu siekia malūną, kitu - apynyną, esantị prie kelio iš Verkių ị Vilnių, apaugęs ịvairiais medžiais. Tarp kalnų griovos, upeliai su akmenų kaskadomis, kanalais, takeliais, išpiltais smulkiais akmenèliais, bei įvairiomis altanomis papuoštas, pirmiausia: netoli aukščiau minėto Vilniaus kelio pirma altana, pastatyta puslankiu iš stačių mūrtašių, jos priekyje medinès kolonos, grindys ir lubos iš lentų. Netoli jos yra nedidelis šliuzas su skrynia, nuo kurio vamzdžiais buvo nuvestas vanduo iki alaus bravoro $^{68}$, dabar visa tai iš esmès sugriauta. Toliau einant yra mūrinis tiltas, suskliaustas virš upelio, tekančio nuo malūno. Jo galuose atramos sumūrytos iš akmenų ir plytų. Perejus tuo tiltu ir einant ị kalną keliu link miestelio, ant kalvelès kairejje pusèje ties kitu upeliu, tekančiu iš to miestelio, mūrinè Bažnyčia $^{69}$, nebaigta, pastatytos tik jos sienos. Grị̌zus atgal iki aukščiau minėto tilto ir nuo jo einant keliu link malūno, kairèje pusėje antras tiltas, suskliaustas iš medžio gabalų, jo galuose atramos taip pat mūrytos iš akmenų ir plytų. Dešinėje pusėje kanalas, aukštai apipiltas žeme ir sutvirtintas medžiu, o iš jo apačioje žeme išvestas vamzdis ị kanalą, iškastą kitoje kelio pusèje, vamzdžio gale įrengtas fontanas, aplinkui apdètas akmenimis; šis kanalas taip pat aukštai užpiltas žeme, o vienoje vietoje, kur vanduo krenta i upelí, yra damba ${ }^{70}$ su mediniu vamzdžiu, t. y. iš akmenų sudèta kaskada. Einant tuo keliu tarp minètų kanalų, iš jo ị dešinę išsuka keliukas, kuriuo einant iš karto kairėje antra altana, pastatyta iš stačių mūrtašių, apskrita, apkalta kvadratinėmis lentelèmis, imituojančiomis tašytą akmenį, aplinkui ją ne visai supa kolonų galerija, kurioje perdengimas ir grindys medinès,

67 Orig.: horno.

68 Čia turimas omenyje senesnis bravoras, minimas $1776 \mathrm{~m}$. inventoriuje kaip jau perdarytas ị garbarnę (1776 m. Verkių palivarko inventorius, 1. 3). $1791 \mathrm{~m}$. inventoriuje garbarnė minima jau kitoje vietoje - ant kalno.

69 Ties šiuo žodžiu pieštuku ịrašyta - Vienybès. 1803 m. inventoriuje minima, kad Vienybès (Iednośći) titulo bažnyčia pusiau apskrita, pastatytos tik jos sienos, netinkuota, be stogo; $1803 \mathrm{~m}$. Verkių dvaro inventorius, 1. 259.

70 Orig.: grobla 
kolonos ir sienos dažytos pelenų spalva, stogas, kad i vidụ patektų šviesa, truputi pakeltas virš sienos, dengtas lentomis; iš prieangio įeinant ị altaną yra dvivèrès fasuotos durys ant vyrių, kablių, su sklendèmis, su prancūziška spyna ir raktu bei žalvariniu rutuliu, dažytos pelenų spalva, altanos viduje grindys molinès, iš kvadratinių juodai degtų plytų, lubos lentinès, lubose didelis apvalus langas su stiklu, sutvirtintas glaistu. Tuo keliuku einant toliau (1. 23v) - nedidelis kanalas, užtvertas damba arba tiltu iš akmenų, o už jo trečia altana, supinta iš vytelių tarp stulpų, dengta šiaudais ir nendrèmis, jos prieangis su medinèmis kolonomis, grindys iš žemės, išpiltos smulkiais akmenukais, iš prieangio durys ị altaną taip pat pintos iš vytelių, lubos taip pat, suoliukai aplink sudèti iš akmenų, langai be stiklų; prie jos nedidelis šulinèlis, suręstas iš nestorų apvalių alksninių rąstelių. Einant toliau tuo takeliu link malūno, yra tiltelis, kurio viduryje lentomis apkalta skrynia ir nedidelis akmenimis apdètas šulinèlis maudynèms. Be aukščiau aprašytu tiltų dar yra maži mediniai tilteliai per įvairias griovas ir upeliūkščius, o upeliuose akmeninès kaskados. Prie upelio, tekančio iš miestelio ${ }^{71}$, jau pačiame parke, yra du karpių priveisti kanalai su dviem didelèmis dambomis, nuo kalno iki kalno sumūrytomis iš akmenų ir plytų, kuriose yra po vieną medini vamzdį vandeniui nutekèti ${ }^{72}$. Prie anksčiau minèto kelio iš Vilniaus i Verkius, ten, kur buvo senas malūnas ${ }^{73}$, yra nedidelis nusausintas tvenkinèlis su sugriauta damba ir šliuzu, o už jo, to upelio įtekèjimo ị Nerị vietoje, mūrinis tiltas, suskliaustas iš plytų, viršuje abipus su mediniais turëklais.

\section{Kanalu ir vandens pralaidu tolesnis aprašymas}

Priešais Naujujų Verkių kaimą ${ }^{74}$, ten, kur prasideda upelis, bègantis ị parką, iš žemių supilta damba su dviem eilèmis įkaltais mediniais poliais $^{75}$, nebaigta. Iš šios vietos planuojama vamzdžiais nuvesti vandenį iki Verkių pilies. Nuo ten einant palei upelį link miestelio, yra didelis neseniai iškastas tvenkinys, o prie jo, ant Vilniaus-Giedraičių vieškelio ${ }^{76}$, didelè iš

71 T. y. Jeruzalès.

72 Šie du ižuvinti kanalai, ịrengti mūrinèmis dambomis užtvenkus iš Jeruzalès tekantį upelį, minimi ir $1802 \mathrm{~m}$.; 1802-1806 m. Verkių dvaro inventorius, l. 6-6v.

73 Medinis malūnas ant mūrinių pamatu, stovèjęs kalno papèdejje, bet davęs nedaug naudos, minimas $1776 \mathrm{~m}$. inventoriuje (1776 m. Verkių palivarko inventorius, 1. 3). Netrukus jis buvo visai nugriautas.

74 Naujujų Verkių kaimu anuomet buvo vadinama gyvenvietė, ịsikūrusi kiek ị šiaurès vakarus nuo Jeruzalès.

75 Orig.: szpuntpal. Tai medinis polis, viename, siauresniame, šone turintis grioveli, o kitame - išsikišantị kantą, taip, kad vieno polio kantas ịsistato ị kito griovelị.

76 Dabar tai Jeruzalès gatvè. 
žemių supilta damba su vienoje pusėje sukaltais poliais, kurios viduryje yra platus vamzdis (jo apačia iš sijų, o šonai ir viršus iš lentų) vandens pertekliui nutekèti, prieš pylimą tvenkinyje tarsi šulinys iš lentų sukaltas, iš kurio dambos apačioje išvesti du vamzdžiai taip pat vandeniui nubėgti. Pačiuose Verkiuose prie malūno yra du tvenkiniai, didesnis ir mažesnis, ǐžuvinti karpiais ir kitokia žuvimi, tarp jų yra supilta damba su sekluma, iš abiejų pusių užkalta poliais, (1. 24) jos viduryje yra šliuzas ir tiltas, išklotas sijomis, su tekintais turèklais abipus, dažytais pelenų spalva; prie to šliuzo iš didesniojo tvenkinio pusės yra užtvara vandeniui praleisti ir sulaikyti, apkaustyta geležimi, su dideliu kabliu ir grandine, einančia ị viršų iki volo, besisukančio ant dviejų geležinių velenų tarp dviejų stulpų, kurio galai apkaustyti dviem geležiniais lankais, stulpuose skylès, $\underset{1}{i}$ kurias įleisti velenai, taip pat apkaustytos geležimi.

Prie smuklès ant Riešės upès kranto didelè damba, apipilta žeme, iš abiejų pusių užkalta poliais, jos viduryje vamzdis iš sijų, užkaišytas ir smaluotas, išvestas dambos apačioje vandens perviršiui nutekèti, prie jo užtvara išleidimui vandens, tekančio senaja vaga ị lentpjūvę, pastatytą Godfrido Reimerio (Reymer) lèšomis, apkaustyta dviem dideliais geležies gabalais su kabliais, tos užtvaros volas su geležiniais lankais, velenais ir dviem grandinėmis, praeitais metais pavogtas. Šios dambos gale po tiltu nauja vaga teka ta pati Riešès upė ir ant jos prieš Kremplių ${ }^{77}$ ežerą yra antra damba su sekluma, aukštai supilta tarp dviejų eilių apačioje sukaltų polių, ant kurių iš rąstų, aptašytų iš dviejų pusių, pastatyta aukšta siena, dar be tilto, pačiame viduryje yra platus vamzdis ant polių, padarytas iš lentų, kitoje dambos pusėje, kur išteka vanduo, šis vamzdis dalijasi, t. y. iš vieno suformuoti du vamzdžiai, viršuje sutvirtinimas medžiu. Šioje vietoje turèjo būti pastatyta $\underline{\text { miedziarnia }}^{78}$. Einant toliau palei tą upę, pratekančią per aukščiau minètą Kremplių ežerą, už jo, Turniškių vietovėje, yra neseniai suformuotas platus tvenkinys, prie kurio pirma damba su poliais užkaltu šliuzu, kurioje yra medinis vamzdis vandeniui nubėgti bei prie jos medinė užtvara be apkaustų; paėjus truputi toliau - kita damba su plačiai iš žemių supilta sekluma, su viena ilga ir plačia mūrine siena, viename gale užkalta poliais, jos viduryje

77 Orig.: Krępl, dabar ežeras vadinamas Naujujų Verkių ežeru, nes prie jo XIX a. pradžioje buvo ịkurtas Naujujų Verkių popieriaus fabrikas.

78 Miedziarnia - tikriausiai vario dirbinių gamykla. Pastatas taip ir nebuvo pastatytas. XIX a. pr. jam skirta damba ir šliuzas jau buvo apgriuvę; 1802-1806 m. Verkių dvaro inventorius, 1. 2. 
apačioje illeistas medinis smaluotas vamzdis vandeniui nutekèti su tokia pačia užtvara be apkaustų. Prie to paties tvenkinio ant upelio, iš tos vietos tekančio link Verkių, trečia damba su poliais užkaltu šliuzu, be tilto ir užtvaros, tik su apatine platforma, kuria krenta vanduo; atskirai po ta platforma (l. 24v) yra nedidelis vamzdis taip pat vandeniui nutekèti. Prieš šią damba iškastas tvenkinys, bet negilus, todèl yra sausas, vandens nepribėga. Iš kitos dambos pusės platus tvenkinys ir prie jo penkta damba, ilga, besitęsianti nuo miško net iki Neries prieigų, šiame gale šliuzas su viena eile sukaltais poliais, su plačiais vartais iš storlenčių ir dviem užtvaromis, prie jos kitoje pusejje iš plytų sumūryti pamatai čia dar numatytai statyti zomšos dirbtuvei ${ }^{79}$. Iš šio tvenkinio teka upelis ị nedidelị tvenkinị, prie kurio pastatyta lentpjūvè, jos neprièjus dar yra tiltas ant stulpų, išklotas lentomis, jis skirtas įvažiuoti ị sodą, jo gale kairèje, prie mūrinio lentpjūvininko namo, gilus griovys, kurị šiais metais net iki Neries išgraužè perteklinis vanduo, jame yra šliuzas, užkaltas poliais, su tiltu pravažiuoti, išklotu lentomis, turintis viduryje tris užtvaras vandeniui išleisti ir sulaikyti. Grịžus atgal iki tvenkinio už aprašytos zomšos dirbtuvès, kitame dambos gale, yra nuo miško iškastas griovys, kuriuo šio tvenkinio vanduo teka ị sodo kanalus, o didžiojo sodo centre yra šliuzas, užkaltas poliais, apačioje su lentine platforma, per kurią krenta vanduo, o prieš ją šone vamzdis, kuriuo vanduo patenka ị kitus vamzdžius ir nuvedamas ị ịvairias sodo vietas, jis sugedęs, reikalingas remonto. Truputị toliau ant to upelio senas laikinas tiltas ant dviejų rąstų, lentomis išklotas pravažiuoti iš sodo ị Verkius, netoli jo: kitas toks pats šliuzas, užkaltas poliais, su lentine platforma apačioje. Tas upelis itteka î platų kanalą (įžuvintą karpiais ir kitomis žuvimis), kuriame yra sala su pastatyta altana. Šalia to kanalo - ilga ir plati damba, kurios viduryje šliuzas su lentomis išklotu tiltu, skersai dambos yra vartai, jų šonai ir apačia išmušta tokiomis pačiomis lentomis, o po jais tokios pačios medienos vamzdis, per kurị, kaip ir pro vartus, krenta vanduo i antrą, taip pat platų ir įžuvintą, kanalą, esantị prie pat bravoro. Einant link kelto yra kita damba, iš abiejų pusių užkalta poliais, jos viduryje yra šliuzas iš tokių pačių polių su lentomis apkaltais vartais ir tiltu, kuris viršuje per vidurị atsidaro; vienoje pusèje dideli dvivèriai, stipriai geležimi apkaustyti vartai, apačioje vamzdis, kuriuo, kaip ir per vartus, krenta vanduo ị paskutini

79 Orig.: zamszarnia. Dirbtuvė nebuvo pastatyta, prie šio tvenkinio $1802 \mathrm{~m}$. jau buvo pradètas statyti naujas malūnas, todèl tvenkinys buvo laikinai nusausintas; 1802-1806 m. Verkių dvaro inventorius, $1.6 \mathrm{v}$. 


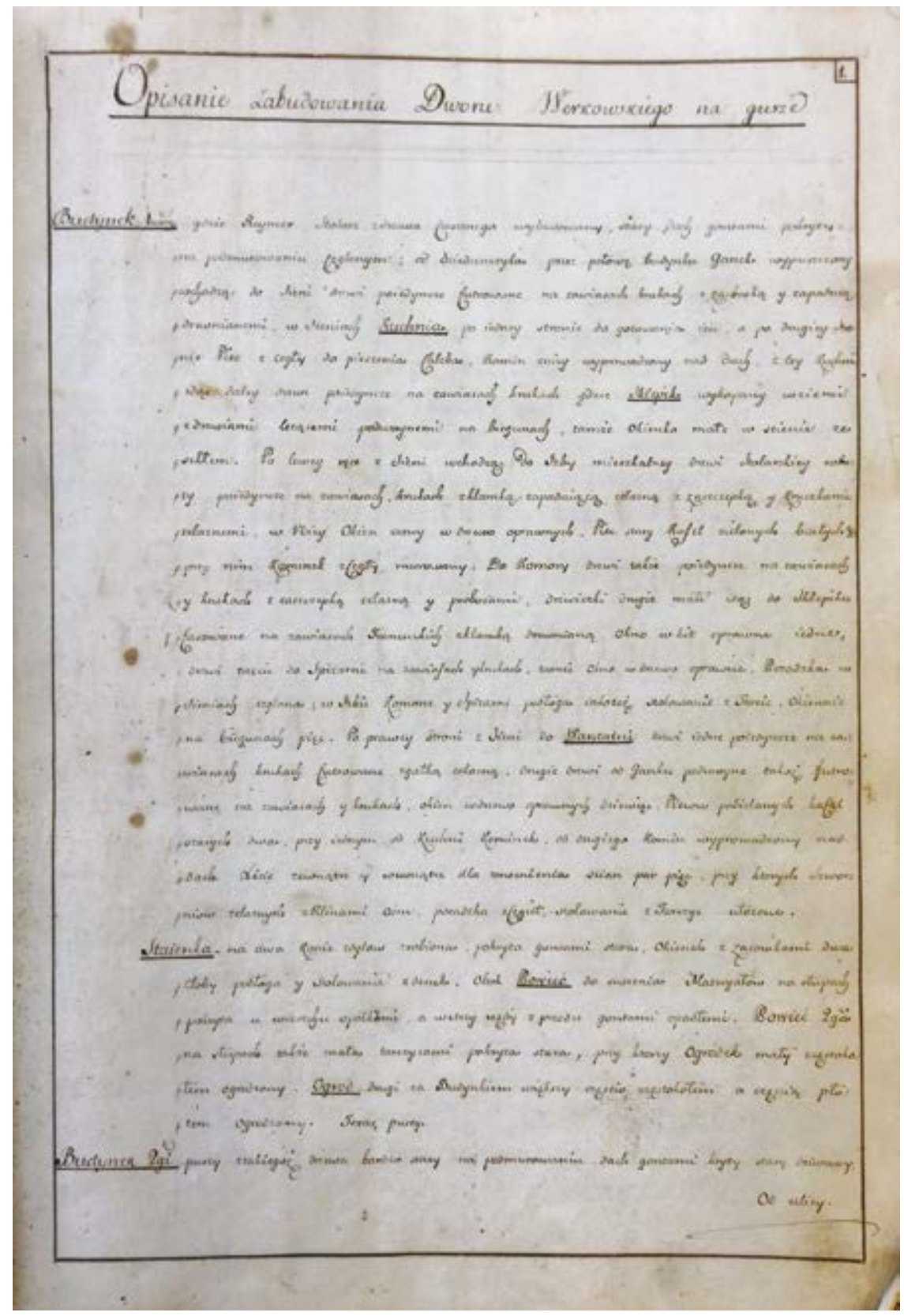

$1791 \mathrm{~m}$. Verkiụ inventoriaus pirmas puslapis
First page of the Verkiai inventory of 1791 
kanalą, kuris galu remiasi ị Nerị, kur yra neilga, bet aukšta žemėmis užpilta, iš abiejų pusių poliais apkalta damba, (1. 25) virš jų dar aukščiau karkasas ${ }^{80}$, pastatytas iš dvišonės medienos, jo viduryje šliuzas su vartais vandens perviršiui nutekèti, iš šonų ir apačioje apkaltas lentomis; po tais vartais atskirai išvestas vamzdis iš lentų žemesniam vandeniui nutekèti ${ }^{81}$.

\section{Ežeru ir upių aprašymas}

1. Pelkètas ežeras vadinamas Dubliškiais ${ }^{82}$, važiuojant iš Verkių i Riešės smuklę kairèje kelio pusėje; jame, be karosų, kitų žuvų nėra.

2. Ežeras priešais, kitoje kelio pusėje, vadinamas Akimi ${ }^{83}$, mažas, jame taip pat, be karosų, kitų žuvų nèra.

3. Ežeras už Dubliškių užežio, bendras su Gulbinais, Linu ${ }^{84}$ vadinamas, jame sugaunami tik karosai.

4. Ežeras už Riešès smuklès vadinamas Viršakiu ${ }^{85}$, kuriame yra karosų ir kuojų.

5. Ežeras vadinamas Kūdra ${ }^{86}$, besijungiantis su Balsio ežeru, kuris priklauso kunigu bonifratrų Kryžiokų palivarkui ${ }^{87}$, jame yra ịvairių žuvų.

6. Mažas ežeras vietovėje ties Krempliais vadinamas [... $]^{88}$, yra karosų.

7. Ežeras, didesnis už tuos visus, vadinamas Krempliais ${ }^{89}$, jame yra gana gausiai sužvejojama ịvairių žuvų.

8. Ežeras raiste prie pačių Verkių vadinamas [... $]^{90}$, jame yra tik karosų.

80 Orig.: zrąb.

811802 m. ši kanalų ir dambų sistema jau buvo pažeista, pažymėta, kad pirmasis kanalas, esantis prie žemutinių sodų ir Neries, yra užverstas ąžuoliniais vamzdžiais ir tik pavasarị jame būna pakankamai vandens, kanale prie bravoro buvo sugedęs šliuzas, todèl taip pat buvo per mažai vandens. Daugiau vandens buvo tik kanale su sala, kurioje stovejo altana; 1802-1806 m. Verkių dvaro inventorius, $1.6 \mathrm{v}$.

82 Orig.: Dubliszki. 1802 m. šio ežero vieta nurodyta taip: „,važiuojant iš Verkių Molètú vieškeliu, kairėje kelio pusėje“; 1802-1806 m. Verkių dvaro inventorius, l. 6v.

83 Orig.: Oczko. Ežeras buvo dešinèje Molètų vieškelio pusėje, mažesnis, bet gilesnis už Dubliškių ežerą (1802-1806 m. Verkių dvaro inventorius, l. 6v). Jis ir dabar telkšo Verkių regioninio parko teritorijoje, apie $0,6 \mathrm{~km}$ i pietus nuo Balsio ežero.

84 Orig.: Lina. Ežeras buvo už Dubliškių užežio, bendras su Gulbinais; 1802-1806 m. Verkiụ dvaro inventorius, $1.6 \mathrm{v}$.

85 Orig.: Wierszakis.

86 Orig.: Sadzawka.

87 Orig.: Krzyzaków. Dabar šie ežerai susijungę ị vieną Balsio ežerą, kartais vadinamą ir Kryžiokų vardu.

88 Pavadinimas neįrašytas.

89 Žr. 55 nuorodą.

90 Pavadinimas neįrašytas. 
Upė Neris su uostu, kurios abu krantai priklauso Verkiams ${ }^{91}$, taip pat maža upė vardu Riešè, gausi įvairių žuvų, tekanti i aukščiau aprašytus apatinius Verkiu kanalus, jos abu krantai priklauso Verkiams.

\section{(1.25v) Apynynų aprašymas}

1. Apynynas ant kalno tarp rūmų kiemo ir kelio, einančio parku iki malūno, mažas.

2. Apynynas tarp parko ir malūno, kitoje upelio pusejje, truputi didesnis.

3. Didžiausias apynynas - tarp parko, senojo malūno ir kelio iš Vilniaus į Verkius.

4. Apynynas truputi toliau link trinitorių valdų, prie to pat kelio, mažesnis.

5. Apynynas tarp to paties kelio ir Neries upès tokio pat ploto.

Palivarko sodų (daržų) aprašymas:

1. Sodas dešinėje pusėje kelio, einančio ị miestelį ${ }^{92}$, prie didesniojo malūno tvenkinio, apsėjamas įvairiomis daržovèmis, jame yra ir obelų. Kitoje kelio pusėje, pirmojo lauko gale, pasodintos obelys ${ }^{93}$.

2. Taip pat ịvairiomis daržovėmis apsėjamas mažas sodas už naujojo klojimo.

3. Sodas, arba medelynas, mažas, sudalytas i keturias dalis, aptvertas statinių tvora su mažomis vienvėrèmis įejjimo durelèmis ant vyrių, jame dviejose dalyse yra skiepytų obelų ir kriaušių, laukinių obelų ir kriaušių, trečia dalis užsodinta įvairiais laukiniais medeliais, o ketvirtoje dalyje auga visokių daržovių ${ }^{94}$ sodinukai.

91 XIX a. pr. inventoriuje nurodyta, kad Verkiams priklauso vienas Neries krantas vienoje pusėje - nuo ribos su Trinapolio trinitorių žeme iki Tiškevičių Liubavo valdų ribos, t. y. daugiau kaip pusantros mylios; 1802-1806 m. Verkių dvaro inventorius, 1. 7.

92 Dabar tai Žaliujų ežerų gatvè.

$931802 \mathrm{~m}$. inventoriuje nurodyta, kad jis kelių margų (margas - apie 0,7 hektaro) ploto; 1802-1806 m. Verkių dvaro inventorius, in: LVIA, f. 1999, ap. 9, b. 6 (Bundesarchiv Koblenz, Nachlass Radziwill, No, 1042), 1. 7.

94 Orig.: wloszczyzna. 
Dirbamų žemės laukụ ${ }^{95}$ aprašymas:

1. Laukas, prasidedantis nuo parko, vienu šonu prie vidurinio lauko, o kitu šonu ir ketvirto šono galu prieina prie Naujuju Verkių kaimo žemių.

2. Laukas, prasidedantis nuo klojimo, plyti tarp pirmo ir trečio lauko, baigiasi prie Naujụjų Verkių kaimo rèžiu ir Skersinès užusienio.

3. Laukas, prasidedantis nuo Gulbinų žemės, plyti tarp antro lauko ir seserims vizitėms priklausančio Gulbinų miško ribos, baigiasi prie Skersinės užusienio žemių.

Pastaba: Visi laukai užima po 120 margu ploto.

\section{(1.26) Dvaro pievu aprašymas:}

1. Pieva prie klojimo ties upeliu, tekančiu ị malūno tvenkinius, vadinama Padvarių $u^{96}$, joje prišienaujama 40 vežimų gero šieno ${ }^{97}$.

2. Pieva tarp pirmojo dirbamo lauko, parko ir miestelio žemių vadinama $[. . .]^{98}$, joje prišienaujama 12 vežimų gero šieno.

3. Pieva prie didesnio malūno tvenkinio tarp kalnų siaura, vadinama Ilga, joje prišienaujami 5 vežimai gero šieno ${ }^{99}$.

4. Pieva tarp tuščių Gulbinų užežio rèžių plati, bet nederlinga, išdalijama valstiečiams, joje vos prišienaujama 10 vežimų pelkių šieno ${ }^{100}$.

5. Pieva, vadinama Šucino ${ }^{101}$, už antrojo kanalo prie zomšos dirbtuvès, joje surenkami 7 vežimai pelkių šieno.

6. Pieva ties upeliu, nusidriekusi link Kremplių ežero, Stoliariškèmis ${ }^{102}$ vadinama, joje prišienaujama 30 vežimų daugiausia pelkių šieno, tik nedidelè dalis - gero.

95 Orig.: zmiana. Labai panašiai laukų padètis aprašyta ir 1803 m. inventoriuje, tik ten pažymèta, kad trečias laukas prasideda nuo Dubliškių, žr. 1803 m. Verkių inventorius, 1. 260.

96 Orig.: Podedworna.

97 Orig.: siana murożnego - Lietuvoje taip buvo vadinamas sausose, ne pelkètose pievose paruoštas šienas.

98 Pavadinimas neįrašytas. XIX a. pr. ši pieva irgi buvo be pavadinimo; $1802-1806 \mathrm{~m}$. Verkių dvaro inventorius, 1. 2.

99 XIX a. pr. paminèta, kad Ilga pieva yra griovyje, $1806 \mathrm{~m}$. ten jau stovejo bravoras; 1802-1806 m. Verkių dvaro inventorius, 1. 2.

100 Orig.: siano błotne.

101 Orig.: Szucina. XIX a. pr. šios pievos padètis aprašyta taip: „nuo tvenkinio su mūrine damba iki kito tvenkinio, kur dabar pastatytas Knofo malūnas“; 1802-1806 m. Verkių dvaro inventorius, $1.2 \mathrm{v}$.

102 Orig.: Stolaryszki. 
7. Pieva Turniškių užežyje, vadinama $[. . .]^{103}$, ją reikia sausinti ir valyti, dabar joje prišienaujama 20 vežimų pelkių šieno.

8. Pieva prie Ožkinių ${ }^{104}$ kaimo, prie Neries, vadinama Verkiškèmis ${ }^{105}$, prie tuščių valstiečių sklypų, joje surenkami 7 vežimai gero šieno.

9. Pieva sklype ${ }^{106}$ prie Neries, mylia ${ }^{107}$ už Ožkinių kaimo, tarp Liubavo $^{108}$, Pakryžès ${ }^{109}$ žemių, vadinama Karveliškèmis ${ }^{110}$, joje prišienaujama 10 vežimų pelkių ir gero šieno.

10. Pieva pusė mylios nuo Karveliškių, prie Nemenčios upelio, taip pat sklype tarp Jos Malonybės Strutinskienès ${ }^{111}$ ir Pakryžès žemių, šienaujama joje 6 vežimai pelkių šieno.

11. Pieva netoli tos, prie tos pačios Nemenčios upelès, trečiame sklype, vadinama [...], ${ }^{112}$ tarp JM Strutinskienès ir Pakryžės žemių, 20 pelkių šieno vežimų.

12. Pieva artimesniame sklype, tarp vaivadienės Jos Malonybės Hilzenienès ${ }^{113}$ Riešès žemių, prie Riešès upès, vadinama [... $]^{114}$, surenkama 15 vežimų pelkių šieno.

13. Pieva kitame sklype tarp tos pačios Jos Malonybès Hilzenienès žemių, taip pat prie Riešès upès, vadinama $[. . .]^{115}$, joje prišienaujama 5 vežimai pelkių šieno.

Suskaičiuota didelių šieno vežimų suma - 187.

(1.26v) Aprašymas įvairiose vietose esančių medžių alëjų

1. Alejja prasideda nuo naujos oficinos, [tęsiasi] tarp slabados ir mūrinès austerijos net iki statybinėms medžiagoms sandèliuoti pastatytos

103 Pavadinimas neịrašytas.

104 Orig.: Oszkince.

105 Orig.: Werkiszki.

106 Orig.: $w$ szachownicy. Szachownica - toliau nuo pagrindinių žemės valdų, tarp kitų savininkų žemių ịsiterpęs žemės plotelis.

107 Mylia - 7 varstai, t. y. $146 \mathrm{~km}$.

108 Orig.: Lubowskie.

109 Orig.: Podkrzyskie.

110 Orig.: Korweliski.

111 Orig.: Strutyńska. Gal turima omenyje Felicijona Teresè iš Karpių Strutinskienè, Braslavo vèliavininko Romualdo Strutinskio (apie 1730-1777) našlè. XIX a. pr. Strutinskienei priklausė Ožkinių seniūnija; 1802-1806 m. Verkių dvaro inventorius, $2 \mathrm{v}$.

112 Pavadinimas neịrašytas

113 Galbūt turima omenyje Konstancija Broel-Pliaterytė-Hilzenienè (Konstancja z Broel-Platerów Hylzenowa, ?-1795), Minsko vaivados Jono Augusto Hilzeno (Jan August Hylzen, 1702-1767) našlè.

114 Pavadinimas neįrašytas.

115 Pavadinimas neįrašytas. 
pašiūrès, apsodinta klevais, liepomis ir kitais medžiais, joje yra [...] viene$\operatorname{tuc}^{116}$.

2. Nuo virtuvės oficinos net iki senojo kafenhauzo viena eile susodinta taip pat įvairių medžių [...] vienetų.

3. Tarp naujos ir virtuvės oficinų bei tarp senụjų ir naujųjų rūmų yra ịvairių medžių, daugiausia šermukšnių ir akacijų [...] vienetų.

4. Alèja, einanti nuo mūrinio ekonomo namo (dom prowentowy) tarp klèčių ir dviaukščio mūrinio namo iki aukščiau paminètos pašiūrès, joje yra įvairių medžių [...] vienetų.

5. Prie kelio nuo malūno tvenkinių per pirmaji dirbamos žemès lauką net iki vieškelio iš Vilniaus ị Giedraičius, medžiai susodinti dviem eilèmis, [...] vienetų.

6. Pradedant nuo trijų medinių namų, esančių netoli klojimo, ịvairūs medžiai susodinti iš abiejų pusių kelio, vedančio ị miestelị ${ }^{117}$.

7. Pradedant nuo miestelio net iki Gulbinų ribos, apibus vieškelio, einančio ị Giedraičius, geriausių medžių [...] vienetų.

8. Nuo to paties miestelio ị kairę, kitu vieškeliu ị Giedraičius, taip pat iš abiejų pusių pasodinta [...] vienetų medžių.

9. Nuo to [Giedraičių] vieškelio, abipus kelio ị Bukiškių palivarką, einančio per Naujujų Verkių kaimo žemę, yra [...] vienetų medžių.

10. Nuo ribos su Trinitoriais iki mūrinio tilto, prie kelio iš Vilniaus i Verkius, iš abiejų pusių pasodinta [...] medžių.

11. Prie parko ratu, o nuo to rato netoli keturiomis linijomis susodinti ịvairūs medžiai, [...] vienetų.

(1. 27) Sąrašas įvairių daiktų, esančių Verkių dvaro nuosavybėje

Grūdais klètyje: rugiu prekybiniais matais - 2 statinès, 3 ašmainiai ${ }^{118}$; žieminių kviečių 1 statinè, 5 ašmainiai; avižų 7 statinès, 3 ašmainiai; grikių 1 statinè, 1 ašmainis; žirnių 1 ašmainis, 5 gorčiai.

Sviesto du kubiliukai, kiekvienas po šešis gorčius, t. y. 12 gorčių.

Paprastos degtinès ${ }^{119} 16$ gorčių; degtinès ratafijos ${ }^{120}$ vienas butelis; ajerų degtinės vienas butelis; apelsinų degtinės vienas gorčius.

116 Čia ir kitur medžių kiekis nenurodytas.

117 Jeruzalę.

118 Ašmainis, orig.: osmina - senovinis mato vienetas, aštuntoji statinès dalis, paprastai atitinkanti 32 gorčius (gorčius - saiko matas lygus apie 2,82-3 litrus).

119 Orig.: wodki ordynaryiney.

120 Ratafija - likeris, užpiltinè, pagardinta vyšnių kauliukais. 
Baltos druskos 18 statinių, 32 gorčiai.

Ivairaus plauko ir amžiaus darbinių palivarko arklių - 8 .

Tvartas: paprastas bulius 1, ariamų jaučiu 13, taip pat Tomaševskio (Tomaszewski), išėjusio iš Skersinès, paliktas 1 bulius ir 1 jautis; melžiamų pieningų karvių 10; melžiamų pirmdèlių karvių 3; senų bergždžių karvių 7; vienmečiu jautukų 3; tokių pačių veršių 7; šiųmetinių veršiukų 2; iš viso ịvairių galvijų: 48.

(1. 27v) Paukščiai: kalakutų ir kalakučiu senų 3, jaunų 18 vienetų, iš viso - 21; žasų ir žąsinų senų 8 , jaunų 40 , iš viso - 48; ančių ir antinų senų 6 , jaunų 40 , iš viso -46 .

Išdirbtos odos: jaučių pilkos, šešioms poroms padụ, ketvirtis; veršių, išdirbtos juodai, 2 vienetai; veršių, išdirbtos pilkai, 15 vienetų; veršių, išdirbtos su kailiu, 13 vienetų; avių, išdirbtos su kailiu, 16 vienetų.

Išvardijimas ivvairių indụ ir daiktų, esančiu svirne ${ }^{121}$ ir ịvairiose Verkiu vietose:

Ivairūs vežimai: seni panaradai ${ }^{122}$ be kopėčių - 3, su kopėčiomis - 1; naudotų ratų obodziaku ${ }^{123}$ tiems panaradams - 12; vasariniai, gerai apkaustyti naudoti vežimai ${ }^{124}-3$; seni, apkaustyti ratai vežimui -9 , neapkaustyti, pataisyti vežimo ratai - 3 ; naudoti žieminiai vežimai - 3 .

Seni pavalkai dviejų arklių kinkiniui - 4, pavalkai vienam arkliui su pakinktais - 1, pavalkai be pakinktų - 3; pavadžiai su vadelėmis ir apynasriu -2 , nauji apynasriai - 4, naujų kamantų - 1 pora.

Dideli virtuviniai vežimai, apkaustyti, išmušti oda ir žaliai nudažyti, -2 , toks pats, tik mažesnis, -1 .

Didelè karieta ant lingių ${ }^{125}$, arba kiszka, apkaustyta, išmušta gelumbe ir oda, dažyta, -1 .

Kalamaška su ratais, neapkaustyta, ir rogès sodininkui -2 .

(1. 28) Žagrès arimui su keturiomis geležinèmis verstuvėmis 6; naudoti noragai ${ }^{126}-9$ poros; naudoti dalgiai šienavimui - 11, nauji - 4, iš viso - 15; naudoti pjautuvai - 16 ; grąžtelis $^{127}-1$; pustyklè dalgiams

121 Orig.: wimbarze.

122 Panaradas - didelis vežimas, ịprastai naudotas didesniems daiktams vežioti.

123 Mediniai ratai, sulenkti iš vieno medžio strypo.

124 Orig.: kary, Lietuvos lenkų tarme taip vadintas paprastas vežimas.

125 Orig.: drąiki.

126 Orig.: narogi.

127 Orig.: świderek grablowy. 
galąsti - 1; akèčios, naujos, naudojamos Žukovskio (Żukowski) Verkiuose, 7; geležinis noragas ${ }^{128}$ žagrei - 1; geležinès šakès puodams iš krosnies išimti - 1; odininko (kailiadirbio) peilis su dviem rankenomis, t. y. drožtuvas - 1; piešnès ${ }^{129}$ ledui skaldyti - 4, kaltas aviliams gaminti - 1 , iš viso - 5; rèžtukai šienui smulkinti -5 .

\section{Ivvairūs ūkiniai padargai:}

Mechanizmas $^{130} \mathrm{su}$ šešiais dideliais dalgiais šiaudams kapoti, reikalingas taisymo - 1; senos geležinès žirklès - 1; trikojai - 2 ir spirgintuvè 1 , iš viso - 3; skliutas mèsai kapoti - 1 , virtuvès ir skerdyklos peiliai - 2 , iš viso - 3; rankiniai pjūklai lentoms pjauti - 2; geležinès keptuvès - 9; ketaus katiliukai - 2; bezmėnas su geležiniu kabliu ir su dirželiu - 1; varinis katiliukas, pasviręs, - 1; senas varinis katiliukas arbatai - 1; varinis butelis su užsukamu kamščiu - 1; didelis kaistuvas su rankena ${ }^{131}-1$, vidutiniai kaistuvai - 2, mažas - 1, iš viso - 4; senas didelis katilas smalai virti Vingyje - 1; didelè alavinė vaza su dangčiu - 1; alavinis dubuo vidutinis - 1; alaviniai pusdubeniai - 2, vieno iš jų kraštai apsilydę; šaukštai alaviniai sveiki - 6, sulaužyti - 4, iš viso - 10; žvakidès alavinès, sugadintos, - 2; (1. 28v) skardiniai dvigubi nieko neverti gorčiai - 2; tokie patys viengubi gorčiai - 2; tokie patys dvigubi geri gorčiai - 2; skardiniai pusgorčiai, niekam netinkami, - 9; tokie patys geri pusgorčiai - 4; skardinių niekam netinkamų kvortų - 12; puskvortès skardinès naujos - 2, sena - 1, iš viso - 3; taip pat senos puskvortès -5 , kvortelès -2 , iš viso -7 ; kreivas laistytuvas -1 , paprasti kvortiniai laistytuvai - 2, iš viso - 3; skardinis dubuo (miednyčia) be dugno - 1, geras kiaurasamtis -1 , iš viso -2 ; skardiniai žibintai didesni -2 , mažesni -2 , iš viso - 4; skardinès žvakidès sveikos -3 , sulaužytos -2 , iš viso - 5 ; stiklinis buteliukas $^{132}$ degtinei - 1; kapoklè daržovėms - 1; fajansinès lèkštès - 4; indų spinta su dviem spynomis, iš kurių viena be rakto - 1; stalas su stalčiumi su spyna ir raktu - 1; senos taburetès, apmuštos žalia gelumbe, - 5; kubilai $^{133}$ degtinei - 5; indai ${ }^{134}$ degtinei - 5; puskubiliai degtinei - 2, statinès

128 Orig.: lemiesz.

129 Orig.: piesznia - ilgas įrankis su aštriais metaliniais galais, skirtas skobti medžiui, pavyzdžiui, drevėms gaminti arba ledui kirsti.

130 Orig.: machina.

131 Orig.: rądel.

132 Orig.: probka.

133 Orig.: kufa - didelis medinis ivvairios talpos kubilas, naudojamas daugiausia alkoholiniu gèrimų gamyboje.

134 Orig.: winiarka - medinis indas, dažniausiai naudotas vynui. 
deginei - 2, iš viso - 4; statinaitès ${ }^{135}$ grūdams supilti - 9; statinès $^{136}$ daržovėms - 2; duonkubilis; kibiras vandeniui; melžtuvè; vonelè; sviestmušė; naminio milo maišelis degtinei - 1; apkaustytos svirtinès svarstyklès šienui sverti - 1 pora; keltuvas sandèlyje su dviem velenais ir lynu, apkaustytas, - 1; kubilai vandeniui vežioti - 2; pūras ${ }^{137}$ druskai sverti, t. y. apkaustyta statinaitè -1 ; ašmainiai: apkaustytas -1 , neapkaustytas -1 , iš viso -2 ; semtuvai, kurių ketvirtis apkaustytas žydo Zavelovičiaus (Zawelowicz) Antakalnyje, -2 .

\section{(1.29) Verkiu kafenhauze}

Svečių kambaryje: kanapèlès, arba suoliukai ${ }^{138}$, beicuoti, ant 4 kojų, prikalti prie sienos, - 8; tokia pati didesnè kanapa ant 6 koju - 1; uosiniai beicuoti staliukai - 5; spintos staliaus darbo, nišose, beicuotos, su spynomis ir raktais, deramai apkaustytos, - 2; taburetės, kimštos ašutais ir gelumbe, jų apvalkalai iš gingaso ${ }^{139}$ audinio, -10 .

Smuklès kambaryje: kanapèlès, arba suoliukai, beicuoti, ant 4 kojų, prikalti prie sienos, - 3; tokia pati didesnè kanapa ant 6 koju - 1; staliukai uosiniai, staliaus darbo, beicuoti, - 5; nauji staliukai su turèklais - 6; tokie patys seni staliukai - 4; spinta su viršuje istiklintomis, o apačioje medinėmis dvivėrèmis durelėmis, su dviem spynomis (pastaba: durelių stiklas sudaužytas) - 1; spinta prie lango, žema, su dviem durelėmis ir dviem stalčiais bei trimis spynomis be raktų - 1; spinta kampe, didelè, su 4, t. y. dviem dvigubomis, durelèmis, su dviem spynomis be raktų ir vienu stalčiumi - 1; suolas su dèže ${ }^{140}$ daiktams susidèti - 1 (pastaba: šie trys baldai staliaus darbo, beicuoti).

\section{Išvardijimas ivairiu indu tame kafenhause:}

Skardinès kvortelès - 3; skardinis puodelis - 1, mažas skardinis piltuvèlis - 1, skardinè žvakidè - 1, skardiniai arbatiniai didesni ir mažesni - 4, skardinė cukrinė - 1, skardinè dèžutè kavai - 1, (1. 29v) skardinis ąsotis senas, penkių gorčių talpos, -1 , žalvarinis padèklas - 1, aukso spalvos

135 Orig.: fasa - kubiliukas, statinaitè, medinis indas.

136 Orig.: stawnia - medinè statinè, indas, kuriame sudedamos daržovės (kopūstai, burokai) žiemai.

137 Pūras čia - 24 gorčių talpos medinis indas.

138 Orig.: zydelki - tam tikri suoliukai, taburetès atmaina.

139 Gingasas - medvilninis įvairių spalvų spausdintas audinys, panašus į perkelį, importuojamas iš Indijos; žr.: Gražina Marija Martinaitienè, Audiniai ir ju spalvos Lietuvos Didžiosios Kunigaikštystès istoriniuose šaltiniuose, Vilnius: Nacionalinis muziejus Lietuvos Didžiosios Kunigaikštystès valdovų rūmai, 2013, p. 59.

140 Orig.: szlabanek. 
metalo $^{141}$ šaukšteliai kavai-2, alavinis kreivas šaukštelis pienui-1, krosnelè kavai skrudinti - 1, malūnèlis kavai - 1, porcelianiniai žydri puodeliai - 3 poros, atskirai lėkštelès prie puodelių - 3, naudoti podgužè ${ }^{142}$ rankšluoščiai 2 , tokios pat naudotos staltiesès -5 , sena staltiesė su žydromis gèlèmis -1 , mažas skardinis žibintas su išdaužtu stiklu - 1 .

Pastaba: aukščiau išvardyti kafenhauzo daiktai yra dvaro apskaitoje, o atskirai pas smuklininką Pominą yra: viengubi skardiniai gorčiai - 3, pusgorčiai - 2, kvorta - 1, puskvortès -3 , kvortelè - 1 , puodelis - 1, piltuvè - 1 , balto stiklo stiklinès -4 , tokio pat stiklo taurelès -2 , senos skardos krosnių angoms uždengti -2 .

Žemutinėje ledainėje pas Jonienę (Janowa): seni skardiniai gorčiai - 2, tokie pat pusgorčiai - 3, tokios pat kvortos -2 , tokios pat puskvortès -3 , kvortelès -2 , puodeliai -2 , piltuvèlis -1 , senas ąsotis -1 .

(1. 30) Name, kuriame anksčiau gyveno Karolis, pas šaltkalvị Andriejų: seni skardiniai gorčiai - 2, pusgorčiai - 2; taip pat skardinės kvortos -2 , puskvortès -2 , kvortelès -2 , puodelis -1 , skardinis piltuvèlis -1 , žalio stiklo dubenèliai ${ }^{143}-3$, tokio pat stiklo stiklinė - 1 .

Miestelio austerijoje pas Hermana: seni skardiniai gorčiai - 5, pusgorčiai - 3, skardinès kvortos - 2, puskvortès - 5, kvortelès - 4, mažas piltuvèlis -1 , didesnis piltuvèlis -1 , skardinis puodelis -1 , skardinès žvakidès -2 , varinis bidonas, įmūrytas ị krosnị, - 1, geležinè skarda krosnies angai uždengti - 1; žalio stiklo stiklinès -6 , taurelès -4 , taurelè -1 ; medinis kubiliukas - 1; paprasti staliaus darbo stalai - 5, aplink stalus didesni suolai - 6, mažesni - 3; staliaus darbo pilkai dažyta spinta su dviem spynomis ir raktais -1 .

Išvardijimas įvairių daiktų, esančių statybiniame sandèlyjje ${ }^{144}$ :

Geležiniai ir variniai: keturbriaunė geležis apie keturių akmenų ir 20 svarų $^{145}$ svorio - 1 liejinys ${ }^{146}$; Karaliaučiaus geležies - 1 liejinys; pailgos geležies mašinai - 1 liejinys, geležis nuo sodo kubilų - 14 vienetų; vežimų ratų apkaustai - 7 vienetai; malūno velenas - 1; malūno volo sutvirtinimo lankas - 1; geležinès skardos mažesni gabalai - 3, didesni - 6; taip

141 Orig.: prezmentalowe. Prezmentalu arba metallum principis Roberti buvo vadinamas metalo lydinys iš keturių dalių vario ir trijų cinko.

142 Podgorze - Krokuvos miesto rajonas, kažkada buvęs atskiras miestas.

143 Orig.: czarka.

144 Orig.: $w$ Imbarze fabrycznym.

145 Lietuviškas akmuo (svorio matas) lygus 40 lietuviškų svarų, o svaras - 384,8 g.

146 Orig.: sztaba. 
pat žalvarinės skardos du su puse svaro; pusantro sieksnio ilgio geležinė grandinè - 1; (1. 30v) dideli geležiniai kabliai - 3; išlietos ịvorès kanalams 23 vienetai; geležiniai kaiščiai - 35; didelès lietos skardos židiniams - 2; senos skardos krosnims - 3, didesnè - 1; kojelès ugniai židinyje įkurti su žalvariniais rutuliukais - 1; maskvietiški kastuvai geri - 36, maskvietiški kastuvai sugadinti - 46; Karaliaučiaus kastuvèliai - 21; gerų mentelių kalkėms maišyti - 16, sugadintų - 4; gerų bigių ${ }^{147}-15$, sugadinta - 1; geležinè sankaba grindims dėti - 1; geležinis kirtiklis ${ }^{148}-1$; geležinè durų sklendè 1; geležinis katiliukas - 1; geležiniai puodai - 2; ketaus siurbliai, sudèti iš kelių atskirų dalių, be medžio, prie jų 6 žiedai kubilams, 2 geležies detalès nuo pompos ir kitos ịvairios detalès, nepilnos - 2; geležiniai sudaužyti, nieko neverti katiliukai - 5; geležinės šakės kalkakmeniams kasti - 1; mechanizmas $^{149}$ akmenims užkelti, septynių dalių, -1 ; geležinis kobinys -1 ; skliutai geri - 8; Karaliaučiaus bindasai ${ }^{150}$, naudoti, -5 , mūrininko mentès - 15; mūrininko plaktukai - 3; akmenskaldžio kalteliai - 57; kalteliai su geležinėmis rankenomis - 13; (1. 31) akmenskaldžio ir ịvairūs pjūklai, pagadinti, - 22; žalvarinis pjūklelis su geležine rankena - 1; prancūziškos spynos su raktais - 5, be raktų - 2; prancūziškos sklendès - 8; žalvariniai paauksuoti apyrakčiai - 2; bezmėnas su diržu - 1; grąžtai vamzdžiams gręžti - 6; geležiniai strypai tiems grąžtams - 2; grąžtai mūrui gręžti - 3; naudoti grąžtai lentjuostèms - 4; ịvairių tipų staliaus obliai be rankenų - 70; staliaus kalteliai įvairaus tipo be rankenų - 8; trišonè dildè - 1; mažos ir didesnès dildès, priklausiusios kalviui Pienkovskiui (Pienkowski), - 36; kreivos dildès - 4; staliaus pjūklelis be rankenos - 1; dailidès kaltai - 2 ; rankenèlès lentpjūvei geležinès - 2; vidutinio dydžio geležinis kampainis - 1; sugadintos kalvio replès -1 ; didelis kalvio kūjis -1 ; žalvarinis ratelis nuo poliakalio - 1; malūno girnų verpstas - 1; langai iš vielos mediniuose rèmuose - 12; žalvarinis pjūklas be dantų su geležine rankena - 1; žalvarinès svarstyklès su žalvariniu svareliu - 1; žalvaris gabaliukais - 3 svarai; varinis katilas valgiui virti - 1; mediniai kãbai, apkaustyti geležimi, - 2; (1. 31v) ąžuolinė apkaustyta boba nuo didžiojo poliakalio - 1, nuo mažesnio - 1, iš viso - 2; poliakalio

147 Bigè - geležinis įrankis trupinti mūrą, ledą ir pan.; žr. Stownik języka polskiego, t. 1: A-O, Wilno: staraniem i kosztem Maurycego Orgelbranda, 1861, p. 80.

148 Orig.: oszkard. İrankis naudotas sienoms griauti; žr. Stownik języka polskiego przez Samuela Bogumita Linde, t. 2, cz. 1: M-O, Warszawa: u Autora, 1809, p. 554.

149 Orig.: machina.

150 Bindasas - tam tikras kirvis. 
varžtai - 8, klemeriai - 2, žalvarinè įvorè - 1 , iš viso - 11; stambių vinių mūrui - 12; žalvarinis katiliukas klijams virti, pakrypęs, - 1; naujos įvairaus svorio jungtys vamzdžiams ${ }^{151}-987$; ankeriai mūrui iš geležies liejinio; balto gipso akmenu - 200; kreidos akmenų - 9; staliaus darbo grindų plokštès, šešiakampès, įvairių spalvų, - 131 vienetas; raudonos spalvos raudonmedžio medienos kaladès ar sijos - 4; didelis kvadratinis raudonmedžio gabalas - 1; braziliškos medienos ${ }^{152}-9$ vienetai; apkaustyta skrynelè nuo pompos - 1 ; didelis marmuro akmuo - 1 .

Išvardijimas įvairių daiktų Verkių malūne pas malūnininką Albertą: Žalvarinės vielos tinkleliai staliaus darbo skrynutėse rafinuotiems miltams -3 , toks pats, tik plonesnès vielos ir neịrėmintas tinklelis -1 , iš viso - 4; geležinès vielos tinkleliai, ịrèminti, -3 , neįrèmintas -1 , iš viso - 4; įvairaus dydžio kūjai akmenims kalti - 7; seni plonesni pikliai, deramai įtaisyti, - 2; drobè pikliui, atvežta iš Rygos, uolekčių [...] $]^{153}$; staliaus darbo dèžès miltams - 2; maža skrynutè pikliavimui, pakabinta ant kãbo, - 1; saikai du, vienas 10 gorčių, kitas 12 gorčių; staliaus darbo staliukas ant vienos kojos su apvadais - 1; pikliavimo dèžè iš senojo malūno - 1; dvivèriai vartai nuo vartų prie vandens rato, apkalti lentelèmis, apkalinèti vinimis, su keturiais dideliais vyriais, -2 ; (1. 32) dideli kaiščiai - 2, ịvorès prie jų - 2, iš viso - 4; geležinis strypas - 1; sena geležinė skarda krosniai - 1; staliaus kirvis - 1; obliai su rankenomis - 4; senas rankinis pjūklas su rankena - 1; vidutinis grąžtas - 1; sena dildè - 1; geležinis skriestuvas - 1; ąžuolinès lentos vandens ratui, sulenktos i apskritimą, - 16; uolekties ilgio skroblo ir obels medžio kūlokai ${ }^{154}$ - 126; plonesnis ašutinis tinklelis - 1 .

Išvardijimas ivvairiu daiktu, esančių Verkiu bravore:

Didelis varinis kvadratinis katilas alui virti krosnyje - 1; didelis skardinis piltuvas -1 ; medinis piltuvas su variniu vamzdeliu - 1 ; seni skardiniai pusgorčiaus talpos ir kvortos talpos laistytuvai - 2; pjūklai skersiniai medžiui pjauti - 3; seni kirviai - 3; sulaužytas kastuvas - 1; kubilas alui su trimis geležiniais žiedais, papuvęs, - 1; kubilas vandeniui, reikalingas taisyti, - 1; kubilas statinėms plauti - 1; alaus vėsintuvas senas, reikalingas remonto, - 1; medinis stovas statinėms alinėje sustatyti su 12 geležinių

151 Orig.: Buxy do rur:

152 Orig.: drzewa brezyliowego. Taip buvo vadinama tam tikra medienos rūšis, gaunama iš medžio Caesalpinia echinata Lam, vertinta dèl raudonos spalvos. Šio medžio kilmė - Brazilija.

153 Skaičius neịrašytas.

154 Orig.: kułak-medinio rato krumplys (malūne). 
žiedų - 1; piltuvai - 3; mediniai kubiliukai dideli - 2, maži - 2; vonelè maža 1 , medinis gorčius - 1 , skardinis dvigubas gorčius - 1 ; statinès alui senos ir geros -85 .

(1. 32v) Išvardijimas įvairių daiktų, esančių Verkių lentpjūvèje, kuriai vadovauja stalius Budrevičius (Budrewicz):

Pjūklai lentoms pjauti - 46; rankinis pjūklelis be rankenos - 1, gražztas didesnis -1 , mažesnis -1 ; obliai su rankenomis -2 , be rankenų -2 ; plokščios dildès - 38, pusapvalès - 2; geležinė juosta, viena $5 / 4$ uolekties ilgio, kita $1 / 4$ uolekties; geležinis raktas dantims tiesinti - 1; geležiniai klemeriai kaladėms laikyti - 19; geležiniai kabliai kaladėms traukti - 2; geležinis kobinys kaladėms gaudyti - 1; dideli kirviai - 4; geležiniai varžtai ịvairiose vietose - 19; Karaliaučiaus geležis po pjūklais $3 / 4$ uolekties ilgio liejiniais, ant rèmų ir po rèmais - 12 vienetų; geležinès rankenos vežimams traukti - 3; nedidelès geležinès piešnès - 2; maskvietiškas kastuvas - 1, Karaliaučiaus kastuvas - 1; geležinis raktas varžtams sukti - 1; geležinės spyruoklès su varžtais pjaunamoms kaladèms pritvirtinti - 2; didelis geležinis plaktukas pleištams po pjūklais įkalti - 1; žalvarinès volų atramos rèmuose - 12, tokios pat didesnès -5 , tokios pat po volais -5 ; geležinès volų atramos virš volų -5 ; ilgi geležiniai kabliai vežimams traukti - 6; dideli geležiniai lankai - 3; dideli geležiniai pleištai po pjūklais - 36; maži geležiniai pleištai po pjūklais - 17; geležies skardos kilnojama krosnelè ugniai įkurti, deramai apkaustyta, - 1; sulaužytas skersinis pjūklas - 1; sena spirgintuvè lajui lydyti gaminant tepalą - 1; skardiniai žibintai su stiklu - 2 .

(1. 33) Verkiu dvaro valstiečiu, t. y. gyvenviečiu, žmoniu, kinkomu gyvulių, žemės ir miškų bei mokesčių ir prievolių aprašymas

Jeruzalès miestelis:

Tuščia sodyba po Petro Tilindžio (Tylindz), 1/4 valako.

Mikalojus Jankauskas (Jankowski) su žmona, sūnūs Mykolas (16) ${ }^{155}$, Andriejus (7), dukros Kotryna (13), Marcijona (9), bendras mokestis $-50^{156}$, metiniai gvoltai - $6^{157}$, arklys -1 , jaučiai -2 , žemès $1 / 2$ valako.

Kristupas Purkevičius (Purkiewicz) su žmona, sūnus Kazimieras (18), dukra Rozalija (14), bendras mokestis - 50, metiniai gvoltai - 6,

155 Skliausteliuose nurodyti asmens metai.

156 Čia ir kitur mokesčiai (činšas su padūme) nurodyti auksinais.

157 Nurodytas privalomų kasmetinių talkų per rugiapjūtę dienų skaičius. 
arklys -1 , jaučiai - 2 , žemès $1 / 2$ valako.

Tuščias sklypas po Jono Zubžickio (Zubrzycki), 1/2 valako, be pastatų.

Juozapas Stankevičius (Stankiewicz) po Jokūbo Daškevičiaus (Daszkiewicz), [vedęs], sūnus Jonas (1/4), dukra Kotryna (4), brolis Tomas (50), bendras mokestis - 50, metiniai gvoltai - 6, arklys - 1, jaučiai - 2, žemès $1 / 2$ valako.

Tuščias sklypas po Jono Mikulevičiaus (Mikulewicz), 1/2 valako, reikia apstatyti.

Mykolas Žegaris (Żegarys, Żegaris) su žmona, dukra Marija (1/4), brolis Simonas (20), bendras mokestis - 50, metiniai gvoltai - 6, arklys - 1 , jaučiai - 2, žemès $1 / 2$ valako.

Dominykas Daškevičius (Daszkiewicz) su žmona, sūnūs Tomas (25), Juozapas (16), Antanas (13), Jurgis (11), dukros Marcijona (24), Marijona (17), bendras mokestis - 50, metiniai gvoltai - 6 , arklys -1 , jaučiai -2 , žemès $1 / 2$ valako.

Jonas Kononovičius (Kononowicz) su žmona, sūnūs Kazimieras (16), Tomas (2), dukra Marijona (15), bendras mokestis - 50, metiniai gvoltai -6 , jaučiai - 2 , žemès $1 / 2$ valako.

Kazimieras Vingrys (Wingrys) su žmona, sūnus Tomas (2), bendras mokestis - 50, metiniai gvoltai - 6 , jaučiai - 2, žemès $1 / 2$ valako.

Simonas Gunevičius su žmona, dukra Kotryna (2), bendras mokestis - 50, metiniai gvoltai - 6 , jaučiai - 2, žemès $1 / 2$ valako.

Tuščia sodyba po Jono Giedrio (Giedrys), 1/2 valako.

Tuščia sodyba po Jurgio Balako (Balak), 1 valakas.

Kazimieras Saulevičius (Saulewicz) su žmona, siuvėjas, sūnūs Juozapas (28), Laurynas su žmona, bendras mokestis - 50, metiniai gvoltai - 6 , kinkomi arkliai - 2, jaučiai - 4, žemès $1 / 2$ valako.

Motiejus Sadovskis (Sadowski) su žmona, sūnus Jokūbas (11), dukra Marijona (2), bendras mokestis - 50, metiniai gvoltai - 6, kinkomi jaučiai - 2 , žemès $1 / 2$ valako.

Tuščias 1 valako sklypas po Vaicechausko (Woyciechowski), kuriame gyvena nusipelnęs Morozas, išlaikomas dvaro. 
Prie smuklès prijungtas 1 tuščias valakas.

Be to, yra 4 apgyvendinimui skirti valakai, kur sklypuose nėra jokių pastatų. Tame pačiame miestelyje yra 10 užstatymui skirtų sklypų be dirbamos žemės, jie driekiasi link Baltupių ${ }^{158}$. <..>

(1. 33v, p. 34) Jurgis Petkevičius (Pietkiewicz), kampininkas, gyvena ant ribos, prie dominikonų bravoro, moka 8 auksinus činšo.

1 pastaba: Jeruzalès miestelio žemès ir sklypai išsidèstę vienu šonu nuo slėnio, kuriuo teka upelis ị parką, ir nuo Naujujų Verkių kaimo šniūrų, kitu šonu nuo atžalyno, kuris turi būti saugomas kaip būsimas iždo miškas, trečiu šonu iš dalies nuo Fabijoniškių kaimo galo, o iš dalies nuo kunigų dominikonų Baltupio žemių, ketvirtu šonu nuo kunigų trinitorių žemès, Kalvarijų dominikonų ir Verkių parko.

2 pastaba: Prie trečios miestelio dirbamų žemių ribos yra dvaro atžalyno plotas, kurio vienas kraštas driekiasi palei visą miestelio šniūrų ilgị, toliau pleištu ribojasi su Fabijoniškių kaimu ir galiausiai su įvairiais Bukiškių užežio užusieniais, o iš dalies remiasi ị Naujujų Verkių kaimo šniūrus. Jis apima 4 valakus ploto. <...>

\section{Naujuju Verkiu kaimas}

Jacekas Žukovskis (Żukowski) su žmona, sūnus Vincentas (20), dukra Kotryna (22), bendras mokestis - 50, metiniai gvoltai - 6, arklys - 1, jaučiai - 2, žemès $1 / 2$ valako.

Tuščias sklypas užstatymui ir apgyvendinimui, žemės $1 / 2$ valako.

Jurgis Stankevičius (Stankiewicz) su žmona, sūnūs Laurynas (12), Mykolas (10), Vincentas (7), posūnis Dominykas Bartoševičius (Bartoszewicz) su žmona, dukros Rožè (2), Marija (1/2), bendras mokestis - 50, metiniai gvoltai - 6 , arklys -1 , jaučiai - 2 , žemès $1 \frac{1}{2}$ valako.

(p. 35) Tuščias sklypas užstatymui ir apgyvendinimui, žemès $1 / 2$ valako.

Motiejus Djakevičius (Dyakiewicz) su žmona, sūnus Vincentas (9), dukros Rozalija (11), Kotryna (6), [taip pat gyvena] pusininkas Juozapas Ravickis (Rawicki) su žmona, sūnūs Antanas (4), Vincentas (2), dukra Agnieška (7), bendras mokestis - 100, metiniai gvoltai - 4, arkliai - 2, jaučiai - 4, žemès 1 valakas. 
Vincentas Kielma (Kiełma) su žmona, sūnūs Ignacas (19), Stanislovas (7), dukros Ona (11), Kotryna (5), bendras mokestis - 50, metiniai gvoltai -6 , arklys -1 , jaučiai -2 , žemès $1 / 2$ valako.

Tuščias sklypas užstatymui ir apgyvendinimui, žemės $1 / 2$ valako.

Tuščias sklypas po Jono Ropienio, žemès 1 valakas.

7 tušti valakai užstatymui ir apgyvendinimui.

Kampininkai su pastatais tuščiuose sklypuose:

Ferdinandas Liuboščinskis (Luboszczyński), kubilius, iki gyvenimo pabaigos.

Lukas Poplavskis (Poplawski), odininkas, bendras mokestis - 8 .

Andriejus Rinkevičius (Rynkiewicz), bendras mokestis - 8 .

Dominykas Kulakauskas (Kułakowski), bendras mokestis - 8 .

Antanas Hovaras (Howar), račius, su Motiejumi Grigaičiu (Grygayc), staliumi, bendras mokestis -8 .

Jonas Orlovskis (Orłowski), stalius, bendras mokestis -8 .

Pastaba: tame kaime kampininkams yra 9 sklypai, pradedant nuo Žukovskio sklypo net iki namo, pastatyto iždo lèšomis, a. a. kunigaikštytès Masalskytės ${ }^{159}$ žindyvei, t. y. Liuboščinskienei, kuri taip pat jau iceina ị tą skaičiu.

2 pastaba: Naujujų Verkių kaimo žemės plyti vienu kraštu nuo dvaro laukelių, antru ir trečiu ribojasi su užusienių sodybomis, t. y. Bukiškèmis, ketvirtu šonu ribojasi su miestelio ${ }^{160}$ šniūrais ir dvaro atžalynu. $<\ldots>$

(p. 36) Kaimas Fabijoniškès

Juozapas Rusakevičius (Rusakiewicz) su žmona, sūnūs Pranciškus (6), Ignacas (4), Jonas (1), dukros Kotryna (12), Rozalija (8), Marijona (7), bendras mokestis -100 , metiniai gvoltai -4 , arklys -1 , jaučiai -3 , žemès 1 valakas.

Petras Čyžas (Czyż) nevedęs, svainis Baltramiejus Rinkevičius (Rynkiewicz) su žmona, sūnūs Antanas (9), Matas (6), dukra Rozalija (7), bendras mokestis -100 , metiniai gvoltai -4 , arklys -1 , jaučiai -2 , žemès 1 valakas.

Mykolas Seniūnas (Seniun) su žmona, sūnūs Vincentas (18), Motiejus (8), dukros Rozalija (12), Ona (8), bendras mokestis - 60 auksinų 20 
grašių, metiniai gvoltai - 4, arklys - 1, jaučiai - 2, žemès $2 / 3$ valako.

Trečdalis Seniūno valako tuščias dèl ginčo su Baltupių dominikonais.

Martynas Senkevičius (Sienkiewicz) su žmona, sūnūs Vincentas (21), Juozapas (18), Pranciškus (11), dukros Rozalija (22), Pranciška (16), Marija (6), bendras mokestis - 100, metiniai gvoltai - 4, arklys - 1, jaučiai 2 , žemès 1 valakas.

Juozapas Lichvinskis (Lichwiński) (po Mykolo Kozlovskio (Kozlowski)) su žmona, sūnus Juozapas (16), dukra Antanina (19), bendras mokestis - 100, metiniai gvoltai - 4, arklys - 1, jaučiai - 2, žemès 1 valakas.

Motiejus Stankevičius (Stankiewicz) su žmona, sūnus Andriejus (2), brolis Vincentas (26), bendras mokestis - 100, metiniai gvoltai - 4, arkliai - 2, jaučiai - 2, žemès 1 valakas.

Tuščia sodyba po Valantovičiaus (Wałantowicz).

Motiejus Ropienis su žmona, sūnūs Jonas (7), Juozapas (5), Vincentas $(1 / 2)$, bendras mokestis - 100, metiniai gvoltai - 4, arklys - 1, jaučiai 4 , žemès 1 valakas.

Vincentas Falkevičius (Falkiewicz) (po Jono Isakovičiaus (Isakowicz)) su žmona, sena motina, bendras mokestis - 50, metiniai gvoltai - 6 , arklys -1 , jaučiai - 1 , žemès $1 / 2$ valako.

$1 / 2$ tuščio valako nuo tos pačios sodybos.

Ponas Karolis Matusevičius (Matusewicz) (po Bieliakovičiaus (Bieliakowicz)), bendras mokestis - 80, žemès 1 valakas.

Martynas Matarevičius (Matarewicz) su žmona, sūnūs Pranciškus, Andriejus, sena motina, bendras mokestis - 50, metiniai gvoltai - 6, kinkomi arkliai - 2 , jaučiai - 2 , žemès $1 / 2$ valako.

$1 / 2$ tuščio valako nuo tos sodybos.

Valakas žemès prijungtas prie smuklès.

Pastaba: šio kaimo žemès iš dviejų pusių ribojasi su dominikonų Baltupiu, iš trečios pusès - su Suderve, iš ketvirtos - su Bukiškèmis, penktu šonu - su [Verkių] dvaro atžalynu, o šeštu - su Jeruzalès miestelio šniūrais $^{161} .<\ldots>$ 


\section{Bukiškių užežis $^{162}$}

Laurynas Bernatovičius (Bernatowicz) su žmona, sūnūs Juozapas (12), Andriejus (8), Pranciškus (1), senas tèvas, bendras mokestis - 100, metiniai gvoltai - 4, arkliai - 2, jaučiai - 4, žemès 1 valakas.

Pastaba: šis užusienis iš vienos pusės ribojasi su Simono Seniūno užusieniu, o antras ir trečias šonas sutampa su Bukiškių siena.

Simonas Seniūnas su žmona, sūnūs Jurgis (7), Simonas (3), dukros Marija (10), Rozalija (6), bendras mokestis - 100, metiniai gvoltai - 4, kinkomi arkliai - 2, jaučiai - 2, žemės 1 valakas.

Pastaba: šis užusienis vienu šonu ribojasi su Bernatovičiaus užusieniu, kitu šonu prieina prie tuščio valako ir dvaro atžalyno, vienu galu prie Fabijoniškių smuklès, kitu - prie Daukšos užusienio.

Tuščias valakas, skirtas apgyvendinimui, plyti vienu šonu nuo Seniūno užusienio, kitu šonu ir vienu galu prieina prie dvaro atžalyno, kitu galu - prie kito tuščio valako ir Šostako (Szostak) užusienio.

Tuščias sklypas apgyvendinimui, plytintis vienu šonu nuo Naujuju Verkių kaimo šniūrų, kitu - nuo Šostako užusienio, vienu galu nuo dvaro atžalyno, kitu - nuo tuščio valako.

Pastaba: tame sklype pastatytas Šstako namas.

Jokūbas Šostakas, našlys, sūnus Laurynas (20), dukros Teresė (22), Marija (14), Rozalija (11), Ona (7), bendras mokestis - 100, metiniai gvoltai - 4, arkliai - 2, jaučiai - 4, žemės 1 valakas.

Tuščias sklypas apgyvendinimui, plytintis vienu šonu nuo Šostako užusienio, kitu - nuo Daukšos užusienio, vienu galu nuo kelio iš Verkių i Bukiškius, kitu - nuo tuščio valako.

Laurynas Daukša (Dauksza) su žmona, dukros Marijona (3), Ona $(1 / 2)$, bendras mokestis - 100, metiniai gvoltai - 4, arkliai - 2, jaučiai - 4, žemės 1 valakas.

(p. 38) Pastaba: Lauryno Daukšos užusienis vienu šonu ribojasi su šalia aprašytu tuščiu sklypu, kitu - su Bukiškių riba, vienu galu remiasi i kelią, einantị iš Verkių į Bukiškius, kitu - į Simono Seniūno užusienị.

Laurynas Šolkovskis (Szołkowski) su žmona, sūnus Motiejus (20), brolis Jokūbas (47), bendras mokestis - 100, metiniai gvoltai - 4, arkliai - 2, 
jaučiai - 4, žemès 1 valakas.

Pastaba: šis užusienis išsidèstęs vienu šonu nuo Bukiškių ribos, kitu - nuo Kristupo Purkevičiaus užusienio, trečiu - nuo tuščio sklypo po Kazimiero Seniūno, ketvirtu - nuo Bukiškių kelio.

Tuščias sklypas po Kazimiero Seniūno, žemès 1 valakas.

Pastaba: tas užusienis išsidèstęs vienu šonu prie Verkių, nuo tuščio valako pusès, kitu - nuo Bukiškių kelio, trečiu - nuo Šolkovskio užusienio, o ketvirtu - iš dalies nuo Purkevičiaus užusienio, o iš dalies nuo tuščio sklypo.

Tuščias sklypas apgyvendinimui, esantis vienu šonu nuo tuščio sklypo po Kazimiero Seniūno, kitu - nuo Bukiškių kelio, trečiu - nuo Pienkovskio užusienio, ketvirtu - nuo Naujųų Verkių kaimo šniūrų.

Vincentas Pienkovskis su žmona, sesuo Magdalena, sena motina, bendras mokestis - 100, metiniai gvoltai - 4, arkliai - 2, jaučiai - 4, žemès 1 valakas.

Pastaba: šis užusienis plyti vienu šonu nuo Naujujų Verkių kaimo šniūrų, kitu - nuo Bartoškos (Bartoszko) užusienio, trečiu ir ketvirtu - nuo tuščių valakų.

Tuščias sklypas apgyvendinimui, plyti vienu šonu nuo Pienkovskio užusienio, kitu - nuo vieno ir kito Bartoškų užusienių, trečiu - nuo Seniūno užusienio dalies, ketvirtu ribojasi su Purkevičių žemėmis.

$<\ldots>$ (p. 39) Kristupas Purkevičius su žmona, brolėnai Jokūbas (21), Kazimieras (18), bendras mokestis - 100, arkliai - 2, jaučiai - 4, žemès 1 valakas.

Pastaba: šis užusienis plyti vienu šonu nuo Šolkovskio ir iš dalies nuo Seniūno užusienių, kitu - nuo Mykolo Purkevičiaus užusienio, vienu galu nuo Bukiškių ribos, kitu - nuo tuščio valako.

Mykolas Purkevičius su žmona, sūnus Gabrielius (22), dukra Marijona (19), bendras mokestis - 100, metiniai gvoltai - 4, arkliai - 3, jaučiai - 4, žemès 1 valakas.

Pastaba: šis užusienis pleištu i̦siterpia tarp Kristupo Purkevičiaus užusienio, Bukiškių ribos, dalies Bartoškos užusienio ir tuščio valako dalies.

Juozapas Bartoška su žmona, bendras mokestis - 100, metiniai gvoltai - 4, arkliai - 2, jaučiai - 4, žemės 1 valakas. 
Pastaba: šis užusienis plyti vienu galu nuo Stanislovo ar Tado Bartoškos ir Stanevičiaus užusienių, kitu - nuo dvaro atžalyno, trečiu - nuo Hilzenų Riešės ribos, ketvirtu - nuo Mykolo Purkevičiaus užusienio, penktu - nuo tuščio valako.

Du valakai miško: prie to paties Bartoškos valako yra du valakai dvaro atžalyno, kuris turi būti saugomas, kol užaugs miškas, jis yra vienu šonu nuo Hilzenų [Riešès] ribos, kitu - nuo Gulbinų ribos, trečiu - nuo Mikulevičiaus (Mikulewicz) užusienio, ketvirtu - nuo Bartoškos ir Stanevičiaus užusienių.

Juozapas Mikulevičius su žmona, sūnūs Ignacas (10), Dominykas (3), dukros Marija (20), Dorota (11), bendras mokestis - 100, metiniai gvoltai -4 , arkliai -2 , jaučiai -4 , žemès 1 valakas. <...>

(p. 40) Pastaba: Juozapo Mikulevičiaus užusienis plyti vienu šonu nuo ką tik aprašyto dvaro atžalyno, kitu - nuo Gulbinų ribos, trečiu - nuo Ropienio užusienio, ketvirtu - nuo Stanevičiaus užusienio.

Motiejus Ropienis su žmona, dukros Elzbieta (20), Marcijona (14), Margarita (7), bendras mokestis - 50, metiniai gvoltai - 6, arklys - 1, jaučiai - 2 , žemès $1 / 2$ valako.

Jonas Mikulevičius su žmona, sūnus Motiejus, dukros Rozalija (3), Juzefa (1/2), bendras mokestis - 50, metiniai gvoltai - 6, arklys - 1, jaučiai - 3, žemès $1 / 2$ valako.

Pastaba: šis užusienis, kartu Ropienio ir Mikulevičiaus, plyti vienu šonu nuo Juozapo Mikulevičiaus užusienio, kitu - nuo Gulbinų ribos, trečiu nuo dvaro atžalyno, ketvirtu - nuo Stanevičiaus užusienio.

Antanas Stanevičius su žmona, sūnūs Juozapas (11), Mykolas (11), dukros Marijona (13), Elzbieta (6), Magdalena (1), bendras mokestis - 100, metiniai gvoltai - 4, arkliai - 2, jaučiai - 4, žemès 1 valakas.

Pastaba: tas užusienis plyti vienu šonu nuo Mikulevičiaus ir Ropienio valako, kitu - nuo Tado Bartoškos valako, vienu galu nuo Juozapo Bartoškos užusienio, kitu - nuo dvaro atžalyno.

Tadas Bartoška su žmona, sūnūs Petras (7), Juozapas (3), bendras mokestis - 100, metiniai gvoltai - 4, arkliai - 3, jaučiai - 4, žemès 1 valakas.

Pastaba: šis užusienis plyti vienu šonu nuo Stanevičiaus valako, 
kitu - nuo Verkių kaimo šniūrų ir Pienkovskio valako, vienu galu nuo Juozapo Bartoškos, kitu - nuo dvaro atžalyno.

Vienas valakas miško: dvaro atžalyno plotas plyti vienu šonu nuo Ropienio, Stanevičiaus ir Tado Bartoškos valakų galų, kitu - nuo Djakevičiaus valako, vienu galu nuo Gulbinų ribos, kitu - nuo Verkių kaimo šniūrų galų. $<\ldots>$

\section{(p. 41) Skersinès užežis}

Kazimieras Djakevičius su žmona, sūnus Mikalojus (11), dukros Rozalija (17), Ona (10), žentas Kasparas Grochovskis (Grochowski) su žmona, bendras mokestis - 100, metiniai gvoltai -4 , arkliai -2, jaučiai -2, žemès 1 valakas.

Jacekas Pienkovskis su žmona, sūnus Jacekas (1/2), sena motina. Pienkovskio pusininkas Jurgis Kurcevičius (Kurcewicz) su žmona, bendras mokestis -100 , metiniai gvoltai -4 , arklys -1 , jaučiai -2 , žemès $1 / 2$ valako.

Po išějusio Motiejaus Tomaševskio (Tomaszewski) - Dominykas Sananovičius (Sananowicz), naujakurys, dẻl ūkinių pastatų blogos būklès atleistas nuo mokesčių ir prievolių iki 1795 m. liepos 1 d., arklys - 1, jaučiai 2 , žemès $1 / 2$ valako.

Pastaba: šitas dviejų valakų užežis plyti vienu galu nuo dvaro atžalyno, kitu - nuo Gulbinų ribos, trečiu - nuo vieškelio, einančio iš Vilniaus i Riešę, o ketvirtu - nuo Naujụjų Verkių kaimo šniūrų ${ }^{163}$.

$<\ldots>$

Dubliškiu užežis

Jonienė Žebrovskienė (Żebrowska), našlè, sūnūs Jonas (17), Motiejus (15), Kazimieras (10), dukros Marija (11), Rozalija (6), Margarita (4), vyro brolis Kazimieras su žmona, bendras mokestis - 150, metiniai gvoltai 6 , arkliai -2 , jaučiai -4 , žemès $1 \frac{112}{2}$ valako.

Pastaba: šis užežis plyti vienu galu nuo [vizičių] Gulbinų ribos, kitu - nuo ežerų ir pelkių, o iš dalies nuo dvaro laukelių.

Gulbinų užežis

Tuščia sodyba po Motiejaus Žebrovskio, žemės 1 valakas.

Motiejus Žebrovskis su žmona, dukra Marijona (20), posūnis Vincentas Bartoševičius, bendras mokestis - 100, metiniai gvoltai - 4, arklys -1 , 
jaučiai - 2, žemės 1 valakas (beje, po Motiejaus Kazlo (Kozel)).

Pastaba: šis užežis trimis sienomis ribojasi su [vizičių] Gulbinais, ketvirta remiasi į dvaro mišką.

(p. 42) Babinių užežis ${ }^{164}$

Jurgis Siatkovskis (Siatkowski) su žmona, sūnus Stanislovas (3), dukros Ona (11), Domicelè (8), posūnis Baltramiejus Balaka, bendras mokestis - 100, metiniai gvoltai - 4, arklys - 1, jaučiai - 2, žemès 1 valakas.

Kazimieras Rodzevičius (Rodziewicz) su žmona, sūnus Tomas (11), dukros Gertrūda (17), Marija (9), bendras mokestis - 50, metiniai gvoltai 6 , arklys -1 , jaučiai - 2 , žemės $1 / 2$ valako.

Mykolas Gžybovskis (Grzybowski) (po Martyno Talačkos (Tołoczko)) su žmona, sūnūs Petras (17), Simonas (9), dukra Magdalena (3), bendras mokestis - 100, metiniai gvoltai - 4, arklys - 1, jaučiai - 2, žemès 1 valakas.

Pusantro valako žemės priklauso Riešès smuklei.

Tuščias sklypas apgyvendinimui, žemės $1 \frac{1 / 2}{2}$ valako. <...>

Kryžiokų užusienis $^{165}$

Kazimierienė Dasevičienė (Dasewiczowa), našlè, sūnūs Antanas (20), Mikalojus (18), Tadas (7), dukros Marijona (19), Marcijona (10), bendras mokestis - 100, metiniai gvoltai - 4, arklys - 1, jaučiai - 4, žemès 1 valakas.

Tuščia sodyba po Dominyko Kozakevičiaus (Kozakiewicz), žemės 1 valakas.

Juozapas Pščolovskis (Pszczołowski) (po Jurgio Balako), nevedęs, sena motina, bendras mokestis - 100, metiniai gvoltai - 4, arklys -1 , jaučiai -2 , žemès 1 valakas. <...>

Stoliariškių užežis ${ }^{166}$

Jonas Minkielis (28), nevedęs, broliai Vincentas (26), Motiejus (24), Mykolas (20), bendras mokestis - 150, metiniai gvoltai - 6, arkliai - 4, jaučiai - 4, žemès $1 \frac{1}{2}$ valako.

Pastaba: šis ūkininkas gyvena ant dvaro žemės, nepadalytos valakais, ir be tikslaus žinojimo, kiek žemès užima, tik laikinai, kol nebus

164 Orig. Babińce. Užežis buvo prie Riešès upès.

165 XIX a. pradžioje Verkiams priklausę Kryžiokai viena linija prièjo prie Neries, ribojosi su Vilniaus bonifratrų vienuolyno Kryžiokų dvaru, dar vadintu Šukštulès vardu, tęsèsi iki bonifratrams priklausiusio Balsio ežero. Netoli tuometinio Molètų kelio, ties riba su Šukštulès valdomis, stovejjo riboženklis - vidutinio dydžio akmuo su išraižytu kryžiumi. Iš kitos pusės Neris ribojo Kryžiokus nuo ponų Čyžų Antavilių ir pono Laškarevo Viršupio; 1802-1806 m. Verkių dvaro inventorius, 1. 1-1v.

166 Užežis Verkių dvaro žemių apsuptyje. 
išmatuota, užrašyta pusantro valako.

\section{$\underline{\text { Užežis prie Krempliư }}^{167}$}

Jonas Gžybovskis su žmona, dukra Petronėlè (6), bendras mokestis - 100, metiniai gvoltai - 4, arklys - 1, jaučiai - 2, žemès 1 valakas.

Simonas Jurevičius (Jurewicz) su žmona, sūnus Jonas (1), dukra Kotryna (3), dèl to, kad žemè bloga, moka tik 80 auksinų mokesčių, metiniai gvoltai - 4, arklys - 1, jaučiai - 2, žemès 1 valakas.

$<\ldots>$

\section{Turniškių užežis ${ }^{168}$}

Juozapas Čaplinskis (Czapliński) su žmona, sūnus Juozapas (4), dukra Juzefa (6), svainė Barbora Tomaševska (Tomaszewska) (26), bendras mokestis - 80, metiniai gvoltai - 4, arklys - 1, jaučiai - 2, žemės 1 valakas.

Juozapas Gosinskis (Gosiński) su žmona, sūnus Kristupas su žmona, bendras mokestis - 80, metiniai gvoltai - 4, arklys - 1, jaučiai - 4, žemès 1 valakas.

Jurgis Švedovičius (Szwedowicz) netoli Minkielio, ant pusès valako dvaro žemės, vedęs, sūnūs Martynas (10), Dominykas (8), Pranciškus (3), svainis Martynas (18), bendras mokestis - 50, metiniai gvoltai - 6, arklys 1 , jaučiai - 2 , žemès $1 / 2$ valako.

Mykolas Jurevičius, naujakurys, ịsikūręs tuščiame sklype prie Neries, vadinamame Repečiškėmis, su žmona, sūnūs Tomas (8), Bartlamiejus (3), sesuo Marijona (6), atleisti nuo prievolių, kol pasistatys ūkinius pastatus, arklys - 1, jaučiai - 2, žemès 1 valakas.

1 pastaba: ūkininkų Čaplinskio ir Gosinskio pastatai yra toje vietoje, kur 12 sklypų išskirta kampininkų ir amatininkų apgyvendinimui, todèl su laiku turès būti iš ten perkelti.

2 pastaba: šiame užežyje buvo trys tušti valakai apgyvendinimui, iš jų vienas skirtas Mykolo Jurevičiaus sodybai, taigi lieka du laisvi valakai. $<\ldots>$

\section{$\underline{\text { Staviškių užežis }}^{169}$}

Jonas Bartoška su žmona, sūnūs Pranciškus (16), Jonas (13), Simonas (10), Vincentas (1), dukros Juozapota (5), Kotryna (4), Marcijona (3), bendras mokestis - 100, metiniai gvoltai-4, arklys - 1, jaučiai-2, žemès 1 valakas. 
Kazimieras Bartoška su žmona, sūnūs Baltramiejus (20), Andriejus (16), Jurgis (12), dukros Ona (22), Juozapota (11), Magdalena (2), bendras mokestis - 100, metiniai gvoltai - 4, arklys - 1, jaučiai - 2, žemès 1 valakas.

Godfridas Reimeris turi lentpjūvę prie Riešès upės, pastatytą savo pirmtako lėšomis, ir Jo Malonybės kunigaikčio Vilniaus vyskupo Masalskio privilegiją, galiojančią iki jo, žmonos ir jų palikuonių gyvos galvos, pagal kurią turėjo mokèti 100 auksinų, bet dabar, kadangi pakreipus Riešès upès vagą link Verkių neteko vandens, nieko nemoka.

Pastaba: prie tos lentpjūvės yra $1 \frac{1}{1} 2$ valako žemės, bet ta žemė yra kalnuota ir blogesnè, todèl moka tik 80 auksinų už valaką - bendras mokestis $-120 .<\ldots>$

\section{Kaimas Ožkiniai ${ }^{170}$}

Motiejus Gulbickis su žmona, sūnūs Kazimieras (24), Andriejus (21), Jurgis (13), Mykolas (11), bendras mokestis - 100, metiniai gvoltai - 4, arkliai - 2, jaučiai - 2, žemès 1 valakas.

Alkevičienė (Alkiewiczowa), našlè, dukros Ona (10), Ieva (7), Marcisia (5), žentas Grigalius Tylinga su žmona, sūnus Gabrielius (2), bendras mokestis - 100, metiniai gvoltai - 4, arkliai - 2 , jaučiai - 2 , žemès 1 valakas.

Juozapas Gaverskis (Gawerski) (po Andriaus Bartoševičiaus) su žmona, posūniai ir podukra Bartoševičiai Mykolas (17), Vincentas (15), Marijona (11), bendras mokestis - 100, metiniai gvoltai - 4, arklys - 1, jaučiai 2 , žemès 1 valakas. <...>

(p. 45) Jonas Rinkevičius (Rynkiewicz) su žmona, sūnūs Dominykas (29), Jurgis (24), bendras mokestis - 100, metiniai gvoltai -4, arkliai -2, jaučiai - 2, žemès 1 valakas.

Kristupas Rinkevičius su žmona, dukros Marijona (10), Kristina (6), Marcijona (4), Ona (2), bendras mokestis - 100, metiniai gvoltai - 4, arklys - 1, jaučiai - 2, žemès 1 valakas.

Kazimieras Daleckis su žmona, sūnūs Kazimieras (22), Vincentas (17), Gabrielius (12), dukros Marcijona (20), Domicelè (13), Magdalena (7), bendras mokestis - 100, metiniai gvoltai - 4, arklys - 1, jaučiai - 2 , žemès 1 valakas. 
Vincentas Klimovičius su žmona, žentas Kristupas Gulbickis su žmona, bendras mokestis - 100, metiniai gvoltai - 4, arkliai - 2, jaučiai - 4, žemès 1 valakas.

Motiejus Voiničius (Woynicz) su žmona, posūniai ir podukros Danovskiai (Danowscy) Jonas (27), Petras (20), Mykolas (11), Rozalija (17), Ona (14), bendras mokestis - 100, metiniai gvoltai - 4, arklys -1 , jaučiai - 2 , žemès 1 valakas.

Andriejus Alkevičius (Alkiewicz), nevedęs, sena motina, svainis Motiejus Gulbickis su žmona ir dukra Marcijona (2), bendras mokestis 100, metiniai gvoltai - 4, arklys - 1, jaučiai - 2, žemès 1 valakas.

Tadas Milevskis (Milewski) (po Stanislovo Danovskio), nevedęs, sesuo našlè, jos sūnus Jonas (17), dukros Kotryna (19), Marijona (11), bendras mokestis - 100, metiniai gvoltai - 4, arklys - 1, jaučiai - 2, žemès 1 valakas.

Motiejus Gniazdovskis (Gniazdowski) (po Izraelio Zavelovičiaus) už žemę ir teisę prekiauti gèrimais Ožkinių kaime kontraktu ịpareigotas mokèti 200 auksinų, bendras mokestis - 100, metiniai gvoltai - 4 .

1 pastaba: nuo šio kaimo link Kryžiokais vadinamo užusienio yra 10 tuščių valakų, skirtų apgyvendinimui, dalis jų ariamos žemės, dalis atžalynų. Tuos tuščius sklypus Ožkinių kaimas turejjo teisę dirbti iki 3 metų už ịsipareigojimą išvalyti trečius savo dirbamos žemės laukus, kurie pateko i pačius atžalynus, vèliau, jei kas naudos tas dykynes, Verkių dvaras gaus už tai atitinkamą mokestį.

2 pastaba: tarp Ožkinių kaimo ir aukščiau aprašytų užežių, kurių padètis neaprašyta todèl, kad jos nèra viena su kita sujungtos, yra didelè dalis atžalyno, kuris privalo būti saugomas dvaro miškui, būtent vietose artimesnèse pačiam Verkių dvarui, sodams ir parkui. <...>

(p. 46) Verkių inventoriaus, t. y. sodybų, gyventojų, valstiečių turto ir žemės, taip pat mokesčių ir prievolių suma

Miestelis Jeruzalè: 10 paprastų sodybų, 1 kampininko sodyba, 26 vyrai $^{171}$, 21 moteris, 7 arkliai, 22 jaučiai, 6 1/2 valako apgyvendintos, 7 1⁄2 valako tuščios žemės, bendri mokesčiai - 508 auksinai, 60 dienų gvolto. 
Naujujų Verkiu kaimas: 4 paprastos sodybos, 7 kampininkų sodybos, 15 vyrų, 14 moteru, 5 arkliai, 10 jaučių, 2 1⁄2 valako apgyvendintos žemės, 9 11/2 valako tuščios žemès, bendri mokesčiai - 298 auksinai, 22 dienos gvolto.

Fabijoniškiụ kaimas: 10 paprastų sodybų, 28 vyrai, 21 moteris, 11 arklių, 20 jaučiu, 9 1/2 valako apgyvendintos žemès, $2 \frac{1}{2} 2$ valako tuščios žemès, bendri mokesčiai - 846 auksinai 20 grašiu, 40 dienų gvolto.

Bukiškio užežis: 14 paprastų sodybu, 33 vyrai, 34 moterys, 28 arkliai, 50 jaučių, 13 valakų apgyvendintos žemès, 6 tušti valakai, 3 valakai miško, bendri mokesčiai - 1300 auksinų, 36 dienos gvolto.

Skersinès užežis: 3 paprastos sodybos, 7 vyrai, 8 moterys, 4 arkliai, 6 jaučiai, 2 valakai apgyvendintos žemès, bendri mokesčiai - 200 auksinų, 8 dienos gvolto.

Dubliškiu užežis: 1 paprasta sodyba, 4 vyrai, 5 moterys, 2 arkliai, 4 jaučiai, 1 1⁄2 valako apgyvendintos žemès, bendri mokesčiai - 150 auksinų, 6 dienos gvolto.

Gulbinų užežis: 1 paprasta sodyba, 2 vyrai, 2 moterys, 1 arklys, 2 jaučiai, 2 valakai apgyvendintos žemės, bendri mokesčiai -100 auksinų, 4 dienos gvolto.

Babiniu užežis: 3 paprastos sodybos, 1 kampininko sodyba, 8 vyrai, 8 moterys, 3 arkliai, 6 jaučiai, 4 valakai apgyvendintos žemès, 1 1/2 tuščio valako, bendri mokesčiai - 250 auksinų, 14 dienų gvolto.

Kryžiokų užežis: 2 paprastos sodybos, 4 vyrai, 4 moterys, 2 arkliai, 6 jaučiai, 2 valakai apgyvendintos žemės, 1 tuščias valakas, bendri mokesčiai - 200 auksinų, 8 dienos gvolto.

Stoliariškiu užežis: 1 paprasta sodyba, 4 vyrai, 4 arkliai, 4 jaučiai, 1 1⁄2 valako apgyvendintos žemès, bendri mokesčiai -150 auksinų, 6 dienos gvolto.

Užežis prie Krempliụ: 2 paprastos sodybos, 3 vyrai, 5 moterys, 2 arkliai, 4 jaučiai, 2 valakai apgyvendintos žemès, bendri mokesčiai 180 auksinu, 8 dienos gvolto.

Turniškiu užežis su Repečiškèmis: 4 paprastos sodybos, 1 kampininko sodyba, 11 vyru, 9 moterys, 4 arkliai, 10 jaučiu, 3 1⁄2 valako apgyvendintos žemès, 2 tušti valakai, bendri mokesčiai - 210 auksinų, 14 dienų gvolto. 
Staviškių užežis: 3 paprastos sodybos, 10 vyru , 8 moterys, 2 arkliai, 4 jaučiai, 3 1⁄2 valako apgyvendintos žemès, bendri mokesčiai - 320 auksinų, 8 dienos gvolto.

Ožkiniu kaimas: 11 paprastų sodybų, 29 vyrai, 28 moterys, 15 arklių, 24 jaučiai, 11 valakų apgyvendintos žemės, 10 tuščiu valakų, bendri mokesčiai - 1100 auksinų, 44 dienos gvolto.

Suma: 69 paprastos sodybos, 10 kampininku, 184 vyrai, 167 moterys, 90 arklių, 172 jaučiai, 64 2/5 apgyvendinto valako, 39 3\%6 tuščio valako, 3 valakai miško, bendri mokesčiai - 5812 auksinų 20 grašių, 298 dienos gvolto.

Tokị inventorių pasirašau: komisaras Kazimieras Hornovskis.

Gauta 20200921 


\title{
Summary
}

\section{The Inventory of the Verkiai Manor of 1791}

\author{
Rūta Janonienè
}

\begin{abstract}
Keywords: Verkiai, Ignacy Jakub Massalski, Wawrzyniec Gucewicz, Kazimierz Hornowski.
\end{abstract}

The period of Bishop Ignacy Jakub Massalski's rule (lived in 17261794) had a special importance in the history of the Verkiai Manor. According to Massalski's agreement with the Vilnius Chapter of 1780, the Verkiai Manor became his patrimony, and a major reconstruction was conducted under the supervision of the architect Wawrzyniec Gucewicz (1753-1798). It is one of the most significant monuments of classicist architecture in Lithuania.

Massalski was nominated Bishop of Vilnius in 1762, but the inventory of 1766 (known from a copy of 1806) basically shows the ensemble as it was left by his predecessors only with minor changes. The inventory of the Verkiai folwark of 1776 reflects the changes that were made in the auxiliary part of the estate. The inventory of the Verkiai Manor of 1791, whose translation is presented here, is the most thorough record of the situation of the ensemble at the end of Massalski's rule. Together with the remains of the archive of this manor, the document is held in the German Federal Archives in Koblenz (Bundesarchiv Koblenz, Nachlass Radziwill, No. 1039). On the initiative of the head of the Mir Castle in Belarus, Dr Olga Popko, in 2016, digital copies of this document along with some other documents from Verkiai were transferred to the Lithuanian State Historical Archives. This publication was prepared on the basis of these documents.

The inventory is compiled very neatly and bound as a separate book. The document is signed by the administrator of the bishop's properties, Kazimierz Hornowski (1756-1818).

Regretfully, it should be noted that the central residential part of the manor, the so-called castle, was not described in the inventory. It 
consisted of a complex of brick buildings: the old manor, the new central manor, and two side servants' quarters. Apparently for this part of the ensemble, a separate inventory was compiled, which has not been found until today. In the rest of the territory of the manor (excluding the pertaining villages), there were more than 50 buildings (the majority were wooden and stood on brick foundations), and there were also several watermills and inns in the territory. All in all, there were more than ten brick buildings, many of which, reconstructed to a larger or lesser extent, have survived until our days. The document contains particularly important information about the two-storey residential house built above the ice-house, today often called a pavilion. From the inventory we learn about its authentic planning and function, as well as the decoration of separate rooms. The porch had a floor of black fired bricks, the rooms were painted in different colours (e.g., grey, green, pink and white), some of the rooms had ornate painted cornices with friezes, and in some places the ceiling was painted blue. The walls of a study on the first-floor were painted dark, decorated with a painted cornice at the ceiling, the ceiling was painted pink, and a tastefully painted landscape depicting a seaport was hung on one of the walls. There are valuable data on wooden classicist houses, undoubtedly also designed by Gucewicz. All the wooden houses built by Gucewicz had a simple symmetrical plan, were painted ash grey, their roofs (like those of the brick buildings) were painted red, and the façades of all houses had larger or smaller column porticos or recessed loggias with columns. There was an impressive sawmill that stood at the Neris River, surrounded by a gallery of forty-two wooden columns. Characteristically, in Gucewicz's buildings, a floor of black fired bricks was often laid in auxiliary buildings or porches, the ceiling was often built from lime and gypsum, and plank ceilings and walls were often used as well. Heating was well-planned in the newly-built houses of Verkiai - modern stoves were built (often covered with brown and coffee-brown tiles), in which ash grids and dampers were installed. All chimney stacks converged into a core chimney at the centre of the roof, and in the larger building - into two chimneys.

The material of the inventory of 1791 could be interesting and important for historical research in various fields - the document not only 
allows us to look at the development of the Verkiai architectural ensemble from a new perspective, but also provides information about the history of the villages and settlements that belonged to the manor, i.e. the northern environs of Vilnius. 